\section{OAK RIDGE \\ NATIONAL LABORATORY}

MARTHW MARIETRA
Oak Ridge National Laboratory Biological Monitoring and Abatement Program for White Oak Creek Watershed and the Clinch River
J. M. Loar
S. M. Adams
L. J. Allison
B. G. Blaylock
H. L. Boston
M. A. Huston
B. L. Kimmel
J. T. Kitchings
C. R. Olsen
J. G. Smith
G. R. Southworth
A. J. Stewart
B. T. Walton 
This report has been reproduced directly from the best available copy.

Available to DOE and DOE contractors from the Office of Scientific and Technical Information, P.O. Box 62, Oak Ridge, TN 37831; prices available from (615) 576-8401, FTS 626-8401.

Available to the public from the National Technical Information Service, U.S. Department of Commerce, 5285 Port Royal Rd., Springfield, VA 22161.

This report was prepared as an account of work sponsored by an agency of the United States Government. Neither the United States Government nor any agency thereof, nor any of their employees, makes any warranty, express or implied, or assumes any legal liability or responsibility for the accuracy, completeness, or usefulness of any information, apparatus, product, or process disclosed, or represents that its use would not infringe privately owned rights. Reference herein to any specific commercial product, process, or service by trade name, trademark, manufacturer, or otherwise, does not necessarily constitute or imply its endorsement, recommendation, or favoring by the United States Government or any agency thereof. The views and opinions of authors expressed herein do not necessarily state or reflect those of the United States Governmerit or any agency thereof. 


\title{
OAK RIDGE NATIONAL LABORATORY BIOLOGICAL MONITORING AND ABATEMENT PROGRAM FOR WHITE OAK CREEK WATERSHED AND THE CLINCH RIVER
}
L. J. Allison
J. T. Kitchings ${ }^{1}$
B. G. Blaylock
C. R. O1sen ${ }^{2}$
H. L. Boston
J. G. Smith
M. A. Huston
G. R. Southworth
B. L. Kimme1
A. J. Stewart
B. T. Walton

${ }^{1}$ Currently affiliated with ERCE, Denver, Colorado.

${ }^{2}$ Currently affiliated with the U.S. Department of Energy, Washington, D.C.

\author{
Environmental Sciences Division \\ Publication No. 3729 \\ Manuscript Completed: June 6, 1986 \\ Date Published: September 1991 \\ Prepared for
}

J. 'T. Kitchings, Manager, Environmental Compliance

Department of Environmental Management

Environmental and Occupational Safety Division

and

T. E. Myrick, Manager

Remedial Action Program

Operations Division

Oak Ridge National Laboratory

Nuclear and Chemical Waste Programs Activity No. KG 0200000

Prepared by the

OAK RIDGE NATIONAL LABORATORY

Oak Ridge, Tennessee 37831-6285 managed by

MARTIN MARIETTA ENERGY SYSTEMS, INC. for the

U.S. DEPARTMENT OF ENERGY

under contract DE-AC05-840R21400

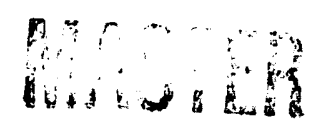


CONTENTS

$\underline{\text { Page }}$

LIST OF FJGURES . . . . . . . . . . . . . . . . . . . . . . . . . . vii

LIST OF TABLES . . . . . . . . . . . . . . . . . . . . . . . . . . iX

LIST OF AGRONYMS . . . . . . . . . . . . . . . . . . . . . . . . . $\mathrm{xi}$

ACKNOWLEDGMENTS . . . . . . . . . . . . . . . . . . . . . . . . xiii

ABSTRACT . . . . . . . . . . . . . . . . . . . . . . . . . $\mathrm{xV}$

1. INTRODUCTION (J. M. LOAT) . . . . . . . . . . . . . . . . . . . 1

1.1 OBJECTIVES . . . . . . . . . . . . . . . . . . . . . . . . 1

1.2 DESCRIPTION OF STUDY AREA . . . . . . . . . . . . . . . . 3

1.3 SELECTION OF SAMPLING SITES . . . . . . . . . . . . . . . 5

2. EXISTING INFORMATION ON ECOLOGY OF WHITE OAK GREEK WATERSHED - 7

2.1 AQUATIC ECOLOGY . . . . . . . . . . . . . . . . . . . . . 7

2.1 .1 Radioecology of White Oak Lake
(B. G. Blaylock)

2.1.2 Bioaccumulation of Nonradiological Contaminants

2.1.3 Surveys of Aquatic Biota, $1950-80$

(J. M. Loar) . . . . . . . . . . . . . . . . . . . 10

2.1 .4 Synoptic Survey, Summer 1985 . . . . . . . . . . . 12

2.1.4.1 Benthic Invertebrate Survey

(J. G. Smith) . . . . . . . . . . . 12

2.1.4.2 Fish Survey (J. M. Loar) . . . . . . . . . 23

2.1.4.3 Amblent Toxicity Evaluation

(A. J. Stewart) .. . . . . . . . . 25

2.2 TERRESTRIAL ECOLOGY . . . . . . . . . . . . . . . . . . . 31

2.2.1 Radioecology (B. T. Walton). . . . . . . . . . . . 31

2.2.2 Surveys of Terrestrial Biota . . . . . . . . . . . . . . 38

3. BIOLOGICAL MONTTORING TASKS .................. . 40

3.1 TOXICITY MONITORING (TASK 1) (A. T. Stewart and

H. L. Boston) . . . . . . . . . . . . . . . . . . . . . . 40

3.1.1 Subtask 1a: Evaluation of Point-and Area-Source

Toxicity (A. J. Stewart) . . . . . . . . . . . 41

3.1.2 Subtask 1b: Ambient Toxicity Testing

(A. J. Stewart) . . . . . . . . . . . . . . . . . . 43

3.1.3 Subtask 1c: Instream Monitoring of Periphyton 
3.2. BIOACCUMU:ATION MONITORING OF NONRADIOLOGICAL

CONTAMINANTS IN AQUATIC BIOTA (TASK 2)

(G. R. Southworth) . . . . . . . . . . . . . . . . . . . 47

3.2.1 Subtask 2a: Identification of Contaminants
that Accumulate in Aquatic Biota . . . . . . . . . 48

3.2.2 Subtask 2b: Identification of Contaminant

3.2.3 Subtask 2c: Integration of Water Quality

3.2.4 Subtask 2d: Evaluation of PCB Contamination . . . 52

3.2.5 Subtask 2e: Bloaccumulation Modeling ...... . . 52

3.3 BIOLOGICAL INDICATORS OF CONTAMINANT-RELATED STRESS

(TASK 3) (S. M. Adems) . . . . . . . . . . . . . . . . . 53

3.3.1 Introduction . . . . . . . . . . . . . . . . . . . 53

3.3.1.1 Advantages of Blological Indicators. . . 56

3.3.1.2 Early Warning Signals of Potential
Environmental Stress... . . . . . . . 56

3.3.1.3 Identification of Mechanisms
Underlying Long-Term Effects....... . 57

3.3.1.4 Cost-Effectiveness and Ease of Use. . . . 59

3.3.2 Description of Subtas'ts . . . . . . . . . . . . . . 60

3.3.2.1 Subtask 3a: Screening and Selection
of Indicators . . . . . . 60

3.3.2.2 Subtask 3b: Application of Biological
Indicators in the Fleld . . . . . . . 64

3.3.2.3 Subtask 3c: Controlled Experiments . . . 65

3.3.3 Sampling Design . . . . . . . . . . . . . . . . . . 67

3.4 INSTREAM ECOLOGICAL MONITORING (TASK 4) . . . . . . . . . . 67

3.4.1 Subtask 4a: Benthic Invertebrates

(J. G. Smith) . . . . . . . . . . . . . . . . . 69

3.4.1.1 White Oak Creek and Tributaries . . . . . 70

3.4.1.2 White Ork Lake . . . . . . . . . . . . . . 73

3.4.2 Subtask 4b: Fishes (J. M. Loar) . . . . . . . . . 74

3.4.2.1 White Oak Creek and Tributaries . . . . . 74

3.4.2.2 White Oak Lake . . . . . . . . . . . . . . 76

3.4.3 Subtasic 4c: Interpretation of Biotic Changes

(M. A. Huston) . . . . . . . . . . . . . . . . . . 77

3.5 ASSESSMENT OF CONTAMINANTS IN THE TERRESTRIAL
ENVIRONMENT (TASK 5) (B. T. Walton) . . . . . . . . . . . . 78

3.5.1 Subtask 5a: Radionuclides . . . . . . . . . . . . 78

3.5.1.1 Subtask 5a, Part 1: Radiologic

Characterization and Risk Anslysis

of Melton Branch Floodplain and the

White Oak Creek Dralnage Area . . . . . . 81

3.5.1.2 Subtask 5a, Part 2: Radioerology of

Tritfum . . . . . . . . . . . . . . . . . 81

3.5.1.3 Subtask 5a, Part 3: Biochemical

Indicators of Radiation Exposure . . . . . 82 
3.5.1.4 Subtask 5a, Part 4: Critical Pathway Analysis--Freshwater Turtles . . . . . . . 84

3.5.1.5 Subtask 5a, Part 5: Critical Pathway Analys is--Waterfow1 . . . . . . . . . . . 85

3.5.2 Subtask 5b: Organics . . . . . . . . . . . . . . . 87

3.5.2.1 Subtask 5b, Part 1: Biochemical Analyses of Vertebrates for Exposure to Hazardous Organics . . . . . . . . . . 88

3.5.2.2 Subtask 5b, Part 2: Biopsy of Animal Fat for PCBs... . . . . . . . . . . . . 89

3.6 RADIOECOLOGY OF WHITE OAK LAKE AND WHITE OAK CREEK (TASK 6) (B. G. Blaylock) . . . . . . . . . . . . . . . . 90 3.6.1 Introduction . . . . . . . . . . . . . . . . . . . 90

3.6.1.1 Radionuclides in White Oak Lake and White Oak Creek Watershed . . . . . . . . 90

3.6.1.2 Objectives . . . . . . . . . . . . . . . . 91

3.6.2 Description of Subtasks . . . . . . . . . . . . . . 92

3.6.2.1 Subtask 6a: Radionuclide Screening . . . 92

3.6.2.2 Subtask 6b: Current Radioecological Status of White Oak Lake. . . . . . . . . 92

3.6.2.3 Subtask 6c: Remobilization of Radionuclides from Sediments . . . . . . . 94

3.7 CONTAMINANT TRANSPORT, DISTRIBUTION, AND FATE IN THE WHITE OAK CREEK EMBAYMENT-CLINCH RIVER-WATTS BAR RESERVOIR SYSTEM (TASK 7)

(B. L. Kimme1 and C. R. 01sen) . . . . . . . . . . . . . . 95

3.7.1 Introduction . . . . . . . . . . . . . . . . . . . 95

3.7.2 Background . . . . . . . . . . . . . . . . . . . . 95

3.7.3 Objectives and Approach . . . . . . . . . . . . . . 97

3.7.4 Description of Subtasks . . . . . . . . . . . . . . 101

3.7.4.1 Subtask 7a: Literature Review and Synthesis . . . . . . . . . . . . . . . 101

3.7.4.2 Subtask 7b: Simulation Modeling of the Embayment-River-Reservolr System . . . 102

3.7.4.3 Subtask 7c: Water Column Processes Governing Contaminant Transport and Fate. . . . . . . . . . . . . . . . . 104

3.7.4.4 Subtask 7d: Contaminant Accumulation in Bottom Sediments . . . . . . . . . . . 108

3.7.5 Summary . . . . . . . . . . . . . . . . . . . . . 110

4. Abatement PROgram (J. T. Kitchings) . . . . . . . . . . . . . . 112

5. REFERENCES . . . . . . . . . . . . . . . . . . 115 
LIST OF FIGURES

Figure

Page

1 White Oak Creek and Clinch River study areas . . . . . . . . 4

2 Location of the 12 sites included in the synoptic benthic and fish surveys conducted in August-September 1985 in White Oak Creek watershed; National Pollutant Discharge Elimination System sites on Melton Branch (X13), White Oak Creek (X14), and White Oak Dam (X15); and liquid and solid radioactive waste disposal/storage areas

3 Comparison of benthos and fish densities at 12 sites on White Oak Creek and selected tributarles (Fifth Creek, First Creek, Northwest Tributary, and Me1ton Branch) . . . . . 26

4 Location of the 16 sites from which water was collected for toxicity tests. . . . . . . . . . . . . . . . . . . . . .

5 Location of White Oak Creek (WOC), Fifth Creek, First Creek, and Northwest Tributary (TWT) sites from which water was taken for measurements of chlorine . . . . . . . . . 30

6 Levels of biological responses in fish to changes in contaminant levels in surface waters, lllustrating the continuum of these responses along gradients of time

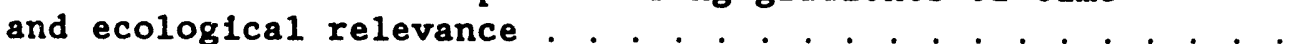

7 Chronic-level responses of organisms to sublethal contaminant stress, emphasizing the importance of energy availability (lipid and nutrient storage pool) f.n the physiological-, pathological-, and organism-level responses of fish to such stress. . . . . . . . . . . . . . . . . . .

8 Proposed locations of sampling sites for benthic invertebrates and fish in White Oak Creek waters'ed; National Pollutant Discharge Elimination Systein sites on Melton Branch (X13), White Oak Creek (X14), and White Oak Dam (X15); and the liquid and solid radioactive waste disposal/storage areas . . . . . . . . . . . 71

9 Relationship between (a) the historical record of ${ }^{137} \mathrm{Cs}$ releases from White Oak Lake and (b) the vertical distribution of ${ }^{137} \mathrm{Cs}$ in bottom sediments of the lower Clinch River (C1inch River kilometer 1.5), with (c) concentrations of organic carbon shown for the lower Clinch River. . . . . . . . . . . . . . . . . . . . . 


\section{LIST OF FIGURES (continued)}

Figure

Page

10 Interrelationships between the proposed subtasks and the research products . . . . . . . . . . . . . . . . . . 100

11 Linked simulation models of the embayment, river, and reservoir . . . . . . . 
1 Mean density (standard error indicated parenthetically), mean number of taxa (range indicated parenthetically), total number of taxa per site, and mean diversity (standard error indicated parenthetically) of benthic invertebrates in White Oak Creek watershed, August 19-20, 1985

2 Mean density (number per $0.1 \mathrm{~m}^{2}$ ) of benthic invertebrates collected from White Oak Creek and tributaries, August 19-20, 1985 . . . . . . . . . . . . . . . . . . . . . . 16

3 Fish densities (number of fish per square meter), total density, and number of species in white Oak Creek and tributaries above White Oak Lake, August-September 1985 . . . 24

4 Mean values for chemical parameters measured in upstream (just north of Bethel Valley Road) and downstream (just upstream from the confluence of First Creek with Northwest Tributary) sites of First Creek, February 20-27, 1986

5 Representative biological indicators that have been used to investigate the biochemical-, physlological-, and tissue-level responses of organisms to various pollutants . . 54

6 U.S. Environmental Protection Agency documents related to the use of various biological indicators in toxicant effects research . . . . . . . . . . . . . . . . . . . . 55

7 Categories of biological indicators to be measured in Subtask $3 a$, the biological responses or conditions reflected by each indicator, and key references that describe the use and application of the indicator 


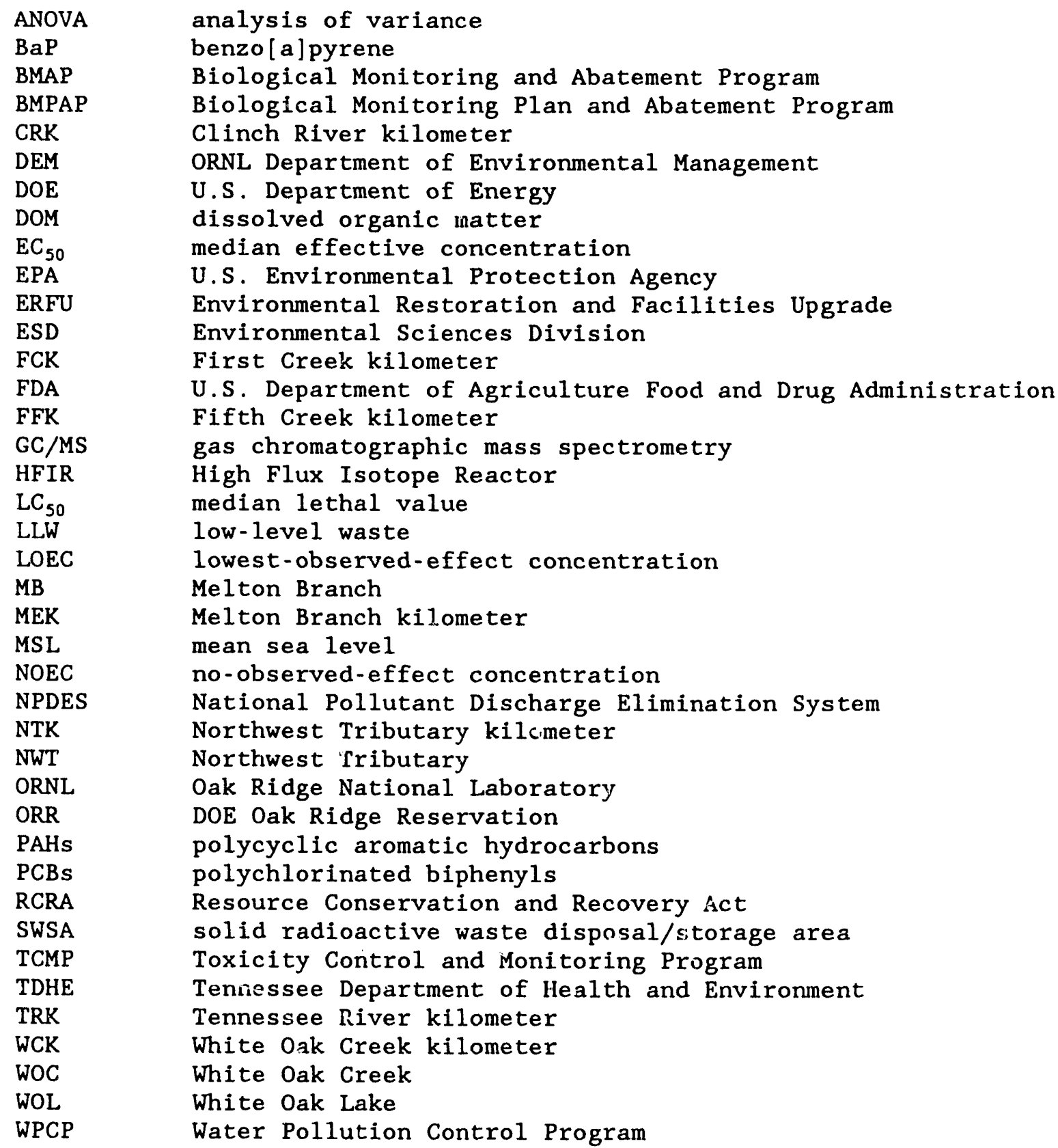




\section{ACKNOWLEDGMENTS}

We thank S. W. Christensen, B. L. Kimme1, J. T. Kitchings, and B. T. Walton for their comments on the draft report. This project was funded in part by the ORNL Department of Environmental Management (currently the ORNL Office of Environmental Compliance and Documentation) and in part by the ORNL Remedial Action Program (currently the ORNL Environmental Restoration Program). Oak Ridge National Laboratory is managed by Martin Marietta Energy Systems, Inc., for the U.S. Department of Energy under contract DE-AC05-840R21400. 


\section{ABSTRACT}

On April 1, 1986, a National Pollutant Discharge Elimination System permit was issued for the Oak Ridge National Laboratory (ORNL). As stipulated in Part III: Special Conditions (Item $H$ ) of the permit, a biological monitoring plan was to be prepared and implemented for White Oak Creek (WOC) and four tributaries (Fifth Creek, First Creek, Melton Branch, and Northwest Tributary) and the Clinch River. The plan, which is formally referred to as the ORNL Biological Monitoring and Abatement Program (BMAP), is described in this report.

The primary purpose of BMAP is to determine if the effluent limits established for the various ORNL facilities protect the classified uses of these receiving streams, especially the growth and propagation of fish and aquatic life, as designated by the Tennessee Department of Health and Environment. Information obtained from this program will be used to (1) characterize the ecological impacts associated with ORNL operations, including both past and present waste disposal activities; (2) assess the potential ecological consequences of various alternatives for remedial action developed under the Resource Conservation and Recovery Act, the Comprehensive Environmental Response, Compensation, and Liability Act, or various ORNL pollution abatement programs; and (3) evaluate the effectiveness of those remedial actions that are implemented.

BMAP consists of seven major tasks that address both radiological and nonradiological contaminants in the aquatic and terrestrial environs at ORNL. These tasks are (1) toxicity monitoring; (2) bioaccumulation of nonradiological contaminants in aquatic biota; (3) biological indicator studies; (4) instream ecological monitoring; (5) assessment of contaminants in the terrestrial environment; (6) radioecology of WOC and White Oak Lake; and (7) contaminant transport, distribution, and fate in the WOC embayment-Clinch River-Watts Bar Reservoir system.

BMAP examines ecological effects at different levels of biological organization, ranging from individual tissues to populations and communities. It also incorporates a variety of approaches, including laboratory studies, manipulative field experiments, and direct instream 
sampling of biota to identify causal mechanisms underlying the observed ecological effects. The overall biological monitoring pian combines established monitoring protocols with innovative, state-of-the-art techniques to document regulatory compliance and to ensure environmental protection and restoration. 


\section{INTRODUCTION}

On April 1, 1986, a National Pollutant Discharge Elimination System (NPDES)* permit was issued for the Oak Ridge National Laboratory (ORNL) (EPA 1986). As specified in Part III: Special Conditions (Item H) of the permit, a plan for biological monitoring of the Clinch River, White Oak Creek (WOC), Northwest Tributary (NWT) of WOC, Melton Branch (MB), Fifth Creek, and First Creek shall be submitted for approval to the U.S. Environmental Protection Agency (EPA) and the Tennessee Department of Health and Environment (TDHE) within 90 days of the effective date of the permit. The plan, which is referred to in Part III (H) of the permit as the Biological Monitoring Plan and Abatement Program (BMPAP), describes characterization monitoring studies to be conducted for the duration of the permit ( 5 years). In order to be consistent with the terminology used for the Biological Monitoring and Abatement Programs for the Oak Ridge Y-12 Plant and the Oak Ridge K-25 Plant, BMPAP will subsequently be referred to as the Biological Monitoring and Abatement Program (BMAP).

The proposed BMAP outlined in this document is based on preliminary discussions held on December 9, 1985, between staff of Martin Marietta Energy Systems, Inc. (ORNL and Central Management), the U.S. Department of energy (DOE), EPA, and TDHE.

\section{OBJECTIVES}

The proposed BMAP was developed to meet several objectives. First, studies (tasks) were designed to provide sufficient data to demonstrate that the effluent limitations established for ORNL protect and maintain the classified uses of WOC and $M B$, as identified in the state of Tennessee Water Quality Management Plan for the Clinch River Basin (TDPH 1978). The two uses of these streams listed in TDPH (1978) are (1) growth and propagation of $\mathrm{fish}$ and aquatic life and (2) livestock watering and wildlife. Although the major emphasis of BMAP is directed

\footnotetext{
*Acronyms used in th.e text of this report are defined in the list on $\mathrm{p} . \mathrm{xi}$.
} 
toward the former, use by wildlife is also addressed in BMAP. Migratory waterfowl and a resident flock of Canada geese utilize white Oak Lake (WOL), and goose hunting on nearby reservoirs was permitted for the first time in 1985. Also in 1985, the first public deer hunts were held since establishment of the Oak Ridge Wildlife Management Area on the DOE Oak Ridge Reservation (ORR) in November 1984.

A second major objective of BMAP is to provide ecological characterizations of WOC and its tributaries and of WOL. Data collected during site characterization should include, inter alia, environmental concentrations and potential impacts on receptors, including both the human populations and the environmental systems susceptible to contaminant exposure (EPA 1985a). The ecological characterization of WOC watershed, including WOL, provided by BMAP, addresses these data needs. This ecological information will be an important component in the eventual development and assessment of remedial action alternatives as part of the Resource Conservation and Recovery Act (RCRA) planning process. The long-term nature of BMAP also ensures that the effectiveness of remedial measures that are implemented will be properly evaluated.

A final objective is to document the effects on stream biota resulting from implementation of a Water Pollution Control Program (WPCP) at ORNL. Planned remedial actions included in the WPCP are two new facilities to improve the management of water pollution. These facilities are the recently completed Sewage Treatment Plant and the Nonradiological Wastewater Treatment Plant (to be constructed by 1990). The latter facility will treat process wastes generated directly in ORNL operations and will provide additional treatment of waste streams that have been pretreated for removal of radioactivity. Unlike the first objective, in which biomonitoring will be used to determine compliance, the latter two objectives are directed toward evaluating currently undetermined remedial actions (Objective 2) and the effects of planned remedial actions, such as specific pollution control measures (Objective 3). 


\subsection{DESCRIPTION OF STUDY AREA}

The WOC drainage basin is located near the southern boundary of ORR and has an area of $16.9 \mathrm{~km}^{2}$ at its mouth at Clinch River kilometer (CRK) 33.5. Parallel northeast-trending ridges constitute the northern and southern borders of the watershed, and a third ridge (Haw Ridge) bisects the basin and separates Bethel Valley to the north from Melton Valley to the south (Fig. 1). Elevations in the watershed range from $226 \mathrm{~m}$ above mean sea level (MSL) at the mouth of WOC to $413 \mathrm{~m} \mathrm{MSL}$ on Melton Hill at the crest of Copper Ridge, the highest point on the $150-\mathrm{km}^{2}$ reservation (McMaster 1963, McMaster and Waller 1965).

The headwaters of WOC originate on the southeast slope of Chestnut Ridge (Fig. 1). The belt of Knox Dolomite underlying the ridge is the principal water-bearing formation, and the springs that occur along the base of Chestnut Ridge and in its valleys are the chief source of the base-flow discharge of WOC (McMaster and Waller 1965). The drainage basin is also underlain by the Rome Formation (Haw Ridge), which is principally composed of siltstone and shale, and the Conasauga Group (Melton Valley), a primary calcareous shale interlayered with limestone and siltstone (McMaster 1963). Both are poor water-bearing formations (McMaster and Waller 1965). Low-flow measurements have shown that 2908 of the flow in the creek originates as groundwater discharge from the Knox Dolomite of Chestnut Ridge, from the Chickamauga Limestone of Bethel Valley, and from ORNL plant effluent (McMaster 1967).

The largest tributary of wOC is MB, which drains an area of $3.8 \mathrm{~km}^{2}$ (McMaster 1967). It originates at the eastern end of Melton Valley and joins WOC $-500 \mathrm{~m}$ above WOL (when the lake elevation is $227.1 \mathrm{~m} \mathrm{MSL}$ ). Although most of ORNL is situated in Bethel Valley, some facilities [e.g., the High Flux Isotope Reactor (the HFIR), solid radioactive waste disposal/storage areas (SWSAs)] are located in Melton Valley. Both MB and WOC receive liquid effluents from ORNL operations and leachates from solid and liquid radioactive waste disposal areas in the drainage basin (Dahlman et al. 1977, Oakes and Shank 1979).

A small highway-fill dam located $1.0 \mathrm{~km}$ above the mouth of WOC impounds the lower portion of the watershed. The small, shallow 

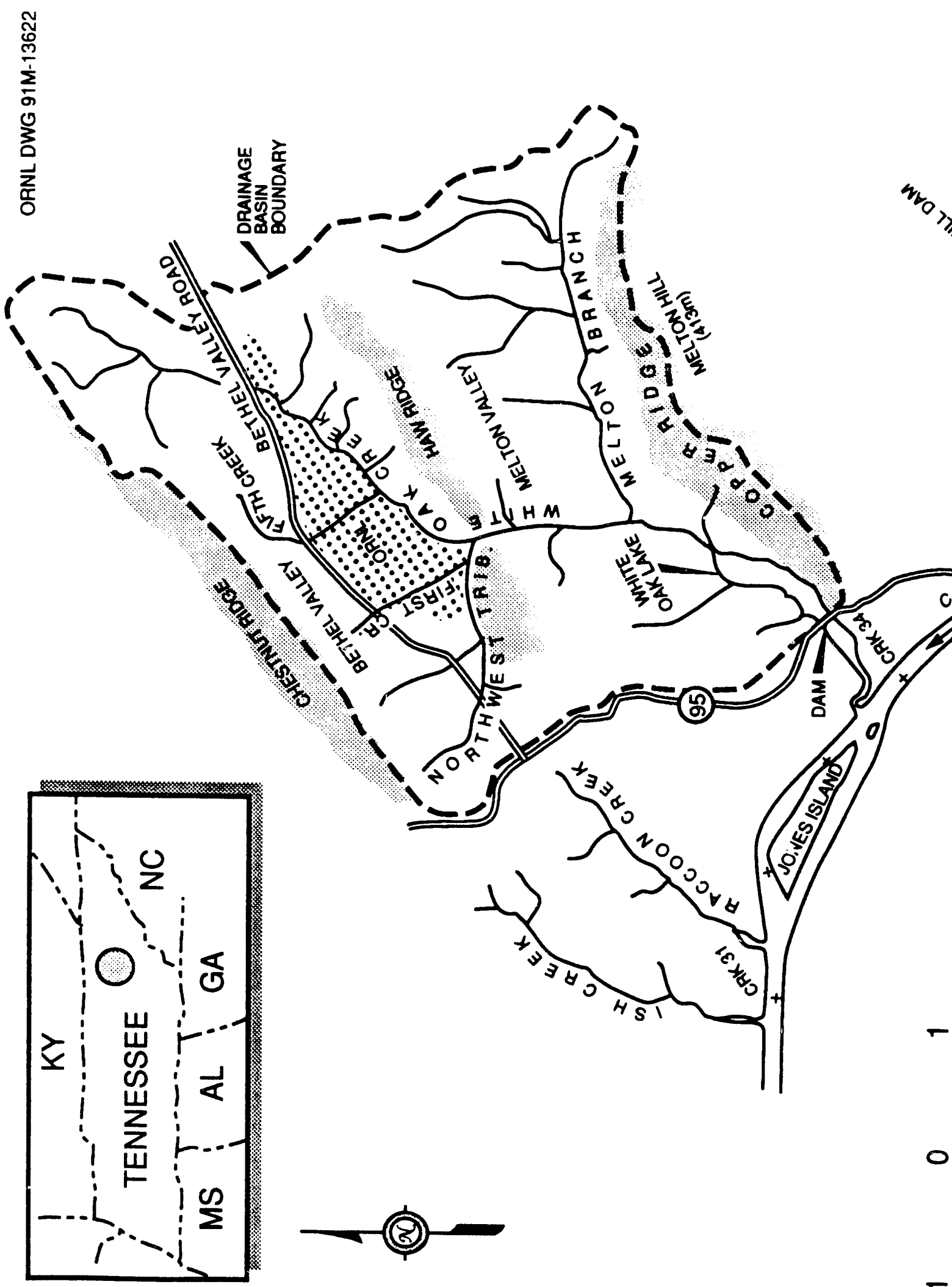

崩

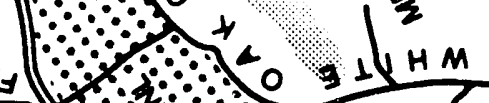
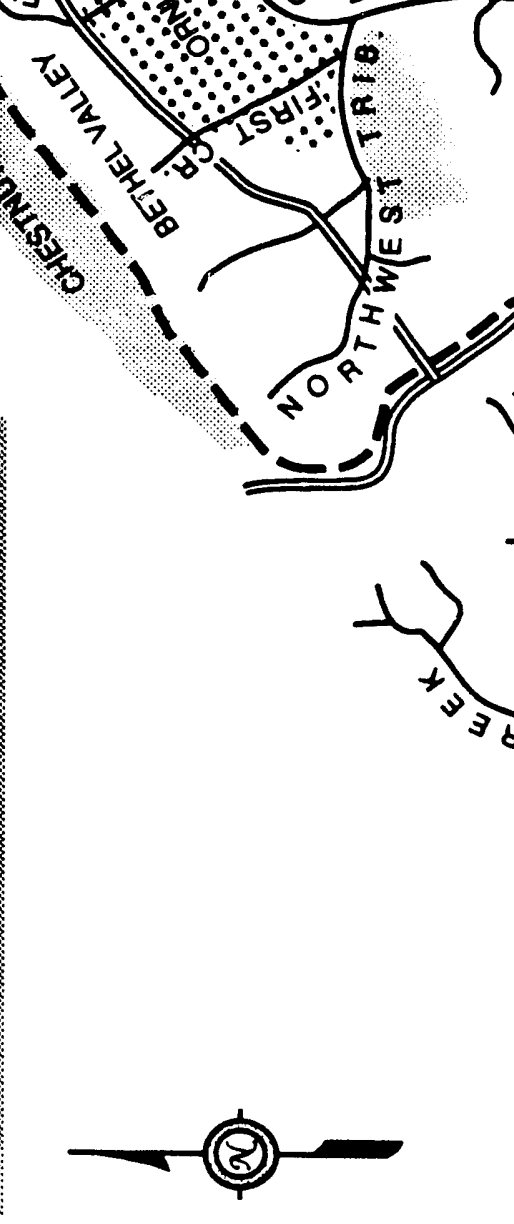

$\int_{\beta_{0}}^{\frac{1}{\beta_{\alpha}}}$

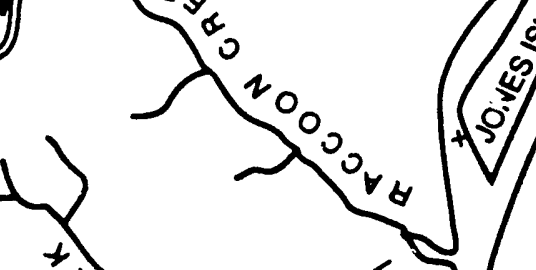

2
0
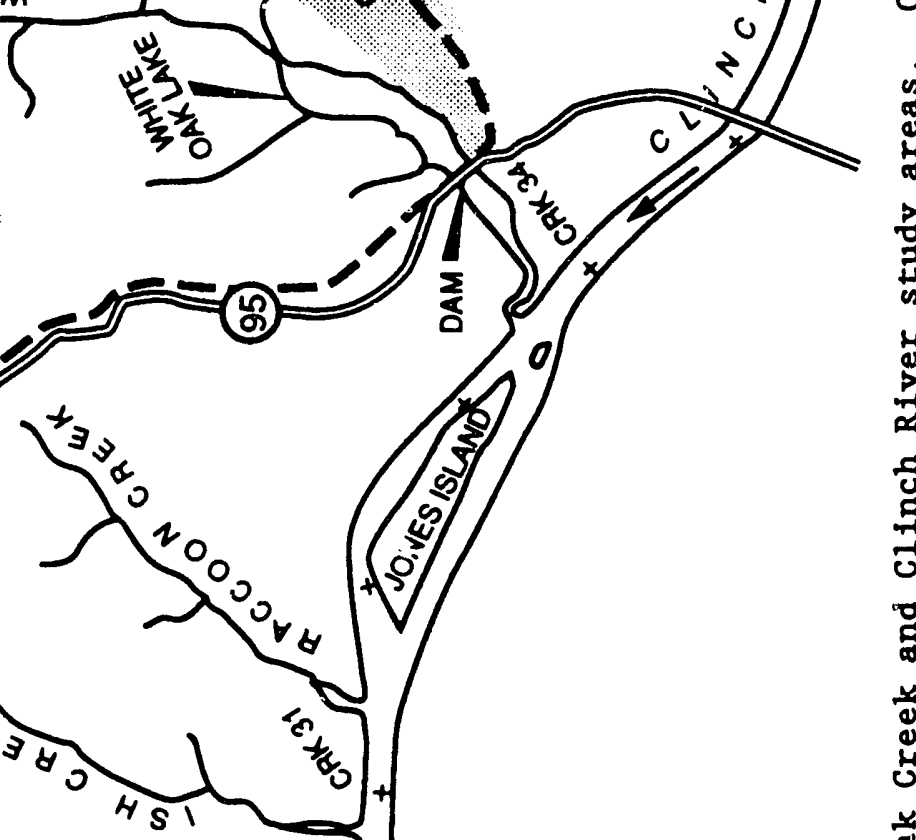

$\stackrel{4}{2}$ 
impoundment (WOL) created by the dam extends $-0.7 \mathrm{~km}$ upstream and has a surface area of -8 ha. Water levels in the creek below the dam are controlled by operation of Melton Hill Dam at CRK 37.2 and Watts Bar Dam, whish is located at Tennessee River kilometer (TRK) 852.6, $-61 \mathrm{~km}$ below the confluence of the $\mathrm{Clinch}$ and Tennessee rivers. When Watts Bar Reservoir is maintained at or near full pool (approximately April to October) and discharges occur at Melton Hill Dam, the subsequent rise in water level in the $\mathrm{Clinch}$ River creates an embayment extending from the mouth of the creek to White Oak Dam. Because of this regulated condition, the WOC watershed is generally considered to be the $15.5-\mathrm{km}^{2}$ area (at a lake elevation of $227.1 \mathrm{~m} \mathrm{MSL}$ ) above the dam (Edgar 1978).

\subsection{SELECTION OF SAMPLING SITES}

Fifteen sites were chosen on WOC and selected tribucaries above WOL for routine sampling of benthic invertebrates and fishes as part of the instream monitoring task (Sect. 3.4). Criteria used in the selection of these sites included (1) point-source discharge locations; (2) area sources with confirmed seepage to surface waters; (3) known areas of impact, as determined from the 1985 synoptic survey (Sect. 2.1.4); and (4) previous sampling locations (e.g., Loar et al. 1981a). Many of these same sites are included in the ambient toxicity testing program (Sect. 3.1). Other tasks, however, will rely on somewhat different criteria for the selection of sampling sites. The abundance and distribution of the target species (bluegill and/or redbreast sunfish), for example, is an important consideration for the contaminant bioaccumulation and biological indicator studies (Sects. 3.2 and 3.3, respectively). Some, but not all, tasks will also involve studies in WOL and downstream, where in some cases specific sampling sites have not yet been identified. Finally, reference (control) sites will not be restricted to upstream areas of small streams within wOC watershed but will include larger streams outside the ORR boundaries (e.g., Brushy Fork, a tributary of Poplar Creek north of Oak Ridge). These streams share several important attributes (e.g., flow rates, physical habitat characteristics) with WOC below ORNL and, in many cases, are more 
appropriate reference sites than the much smaller headwater streams in the wOC watershed.

In preparing BMAP, consideration was given to the temporal and spatial variability in contaminant sources. Existing water quality conditions in wOC reflect different sources of contaminants, including (1) point-scurce discharges from ORNL facilities; (2) nonpoint sources, such as contaminated groundwater seepage from SWSAs; and (3) sediments of WOC, which may contain contaminants released in the past (Boyle et al. 1982). Moreover, the small tributary drainages, such as First Creek, Fifth Creek, NWT, and MB, have facilities that discharge directly to the stream (i.e., point sources) and area sources, such as SWSAs or process ponds that may also contribute contaminants to the streams. To this existing level of spatial complexity associated with the contaminant sources to WOC is added temporal complexity, because the composition of most process waste streams will change as various planned remedial actions are implemented. 


\title{
2. EXISTING INFORMATION ON ECOLOGY OF WHITE OAK CREEK WATERSHED
}

\begin{abstract}
Many studies of the aquatic and terrestrial ecology of WOC watershed and WOL were conducted over the past 35 years. Because ORNL effluents contain levels of radionuclides that are substantially above background and not typically found in industrial effluents, many of the earlier studies focused on radioecological effects. Other studies were actually surveys that described the biotic communities in the watershed. Although both types of studies are reviewed in the following paragraphs, detailed descriptions of the aquatic and terrestrial communities are not presented. Such information is readily available from the references cited in the text.
\end{abstract}

\subsection{AQUATIC ECOLOGY}

\subsubsection{Radioecology of White Oak Lake}

Numerous studies have been conducted on the accumulation of radionuclides by fish in WOL. With the exception of the ORNL monitoring program that is conducted in wOC embayment and the Clinch River (Martin Marietta Energy Systems, Inc. 1985) and a study of the distribution of tritium (Blaylock and Frank 1979), most of these investigations were conducted in the late 1960s and early 1970s. A summary of these studies can be found in Oakes et al. (1982a) and Sherwood and Loar (1987).

The influence of trophic level on the concentration of ${ }^{137} \mathrm{Cs},{ }^{60} \mathrm{Co}$, and ${ }^{90} \mathrm{Sr}$ was determined for five species of fish in wOL by Kevern and Griffith (1966). No correlation was found between trophic level and radionuclide concentration. A comprehensive study on the cycling of ${ }^{137} \mathrm{Cs}$ in bluegill was carried out by Kolehmainen and Nelson (1969). Results indicated the concentration of ${ }^{137} \mathrm{Cs}$ increased 1 inearly with size up to $70 \mathrm{~g}$. A seasonal variation in the ${ }^{137} \mathrm{Cs}$ level in bluegill was observed, with the maximum concentration occurring in February and the minimum in August. Concentrations of ${ }^{137} \mathrm{Cs}$ in other fish species were also determined, and all species displayed a seasonal cycle similar to bluegill. 
Investigations of the accumulation of radionuclides in bluegill, gizzard shad, and goldfish and studies of their feeding habits in wOL were conducted by Nelson et a1. (1970). Fish were collected monthly from WOL from April 1969 to May 1970. Cesium-137 and ${ }^{60}$ Co were consistently found in the fish. Ruthenium-106, ${ }^{125} \mathrm{Sb}$, and ${ }^{65} \mathrm{Zr}$ occurred in small quantities in all three species, but the contribution of these three radionuclides to the body burden of the fish was insignificant.

Other radionuclides have been found at very low concentrations in fish in WOL. Eyman and Trabalka (1980) determined that the concentration of ${ }^{239,240} \mathrm{Pu}$ in bluegill, goldfish, shad, and largemouth bass ranged from $2 \times 10^{-4}$ to $1 \times 10^{-3} \mathrm{pCi} / \mathrm{g}$ fresh weight. The concentrations of tritium in algae, aquatic plants, benthic invertebrates, and fish were usually less than the concentration in the lake water, which ranged from 403 to $646 \mathrm{pCi} / \mathrm{mL}$ in 1978 (Blaylock and Frank 1979).

Organisms inhabiting WOL are irradiated not only from external sources in water and sediment but also from internal sources as a result of consuming food that has accumulated radionuclides from an environment contaminated with significantly higher than background levels of radionuclides. In addition to the potential effect that radiation could have on natural populations of organisms inhabiting WOL, a pathway exists for the transfer of radionuclides through the aquatic food chain to humans by the consumption of fish.

One of the earliest ecological studies of WOL and WOC was a survey to determine the radioactivity in the biota and to document the effect on survival rates, population balances, and types of organisms that were affected (Krumholz 1954a, 1954b, 1954c). In the early studies, gross beta activity was usually reported for the biota instead of the concentration of specific radionuclides. In addition, the inherent variability in the parameters that were being measured on populations would preclude effects of radiation from being detected at the dose rates the biota were receiving. From 1961 to 1977 a series of studies was carried out on the midge population (Chironomus tentans) (Blaylock 1965, 1966); the mosquitofish population (Gambusia affinis) (Blaylock 1969, Trabalka and Allen 1977); and the snail population (Physa 
heterostropha) (Cooley 1973) that inhabited WOL to determine the effects of irradiation. Blaylock and Trabalka (1978) concluded in an evaluation of these studies that it is highly unlikely that radiation effects on the populations of aquatic organisms that inhabit wOL would be detectable because of the decreasing dose rate being received by the organisms as a result of a decrease in the level of radioactivity in the lake over the years.

A nore detailed review of the radionuclides in water and sediment of WOL is presented in Sherwood and Loar (1987).

\subsubsection{Bioaccumulation of Nonradiological Contaminants}

WOC, MB, WOL, and WOC embayment water and sediments contain metals, organic chemicals, and radionuclides as a result of current and past discharges from ORNL (Boyle et al. 1982). Fish collected from WOL and WOC embayment in 1979 (Loar et al. 1981a) and 1984 (TVA 1985) contained elevated levels of mercury, but the levels in 1984 were well below the 1-ppm U.S. Department of Agriculture Food and Drug Administration (FDA) action limit and were significantly lower than levels observed in 1979. A comprehensive water-quality survey conducted in 1979 documented a sharp increase in aqueous-phase mercury levels in WOC as it passed through the central ORNL complex and a large decrease in aqueous-phase mercury after passage through WOL (Boyle et al. 1982). Levels of mercury in biota in WOC and MB above WOL have not been measured. Measurements of aqueous-phase mercury levels made in 1985 suggest that releases have decreased substantially since 1979-80, but measurements on a single date are not adequate to demonstrate such a decrease.

The concentrations of other metals, particularly $\mathrm{Zn}, \mathrm{Cr}$, and $\mathrm{Cu}$, are slightly elevated above background levels in WOC and MB (Boyle et a1. 1982). Measurements of other trace metals in fish from WOL and WOC embayment in 1979 (Loar et al. 1981a) and 1984 (TVA 1985) indicated that metals other than mercury did not exceed background levels. No measurements have been made of trace metals in fish upstream of WOL.

Polychlorinated biphenyls (PCBs) appear to constitute the most significant bioaccumulation problem associated with ORNL. High levels of PCBs were observed in WOC sediments in 1979 (Boyle et al. 1982), and 
levels in excess of the FDA action limit were found in all channel catfish collected in 1984 from WOC embayment (TVA 1985). In the latter study, however, high levels of PCBs were not found in carp from wOL. Monitoring of PCBs in fish (carp, bluegill, largemouth bass, shad) from the Clinch River at the mouth of WOC indicated levels above background, but most fish had PCB concentrations well below the FDA limit (Martin Marietta Energy Systems, Inc. 1985). One of four sediment cores taken in WOC embayment in 1984 was high in PCBs, while the others were below detection limits. The data suggest that a "hot spot" of PCB-contaminated sediments, which acts as a source of PCB contamination to bottom-dwelling fishes (such as channel catfish), occurs somewhere in WOC embayment. Reconstruction of the White Oak Dam spillway, completed in 1983, may have released buried PCB-contaminated sediments from WOL, which then accumulated in depositional areas in WOC embayment. No significant accumulation of other organic compounds was observed in fish from wOL or WOC embayment in 1984 (TVA 1985). Chloroform was reported in two catfish from WOC embayment, but the low bioaccumulation potential of this compound (Callahan et al. 1979) makes its actual presence in fish highly unlikely. One sediment core from WOC embayment contained $1.6 \mathrm{ppm}$ bis(2-ethylhexyl)phthalate. This substance has a moderate bioaccumulation potential (Cállahan et. al. 1979) but poses a relatively low risk to consumers (Hoffman et al. 1984).

\subsubsection{Surveys of Aquatic Blota, 1950-80}

The aquatic biota of the WOC watershed, including WOL, were first characterized more than 30 years ago by Krumholz (1954a, 1954b, 1954c). This initial survey, which described the composition and abundance of the plankton, benthic macroinvertebrate, and fish communities, was followed by several other studies of a more limited scope. The protozoan and phytoplankton communities in wOL were investigated during the summer of 1956 (Lackey 1957). The composition of the fish community in the lake has been described by Kolehmainen and Nelson (1969) and Auerbach (1974); the nonradioiogical data collected in all three studies consisted primarily of species lists. Rather limited (but quantitative) sampling of the phytoplankton and zooplankton communities in WOL was 
conducted in 1972-73 (A. S. Bradshaw, Oak Ridge National Laboratory, unpublished data), and the benthic macroinvertebrate communities were sampled at six sites in wOC watershed in 1974-75 (B. G. Blaylock, Oak Ridge National Laboratory, unpublished data).

The first comprehensive ecological survey of the watershed since 1953 was conducted from March 1979 through June 1980 to characterize the biological communitie at selected sites on WOC above and below ORNL and on the Clinch River upstream and downstream from the confluence of wOC (Loar et al. 1981a). The periphyton, benthic invertebrate, and fish communities were sampled at four sites in WOC watershed above WOL; these communities and three others (phytoplankton, zooplankton, and ichthyoplankton) were sampled in WOL, WOC embayment, and the Clinch River (Fig. 1). The baseline information obtained by Loar et al. (1981a), which was subsequently used to assess the nonradiological environmental impacts resulting from ORNL operations (Boyle et a1. 1982), indicated degradation of the aquatic environment in wOC below ORNL. Of particular significance were the absince of fishes and the low diversity of benthic invertebrates at several sites. Potential causes of these impacts are (1) individual pollutants present at toxic levels; (2) multiple pollutants, acting synergistically; and (3) toxicants that have accumulated over the years in the sediments of WOC (Boyle et a1. 1982).

In summary, most of the previous studies of the aquatic ecology of the WOC watershed focused on evaluation of the radioecological effects of ORNL discharges and were not designed to characterize the aquatic biota (i.e., the composition, abundance, and distribution of biotic communities). Only the 1950-53 and 1979-80 surveys conducted by Krumholz (1954a, 1954b, 1954c) and Loar et al. (1981a), respectively, provided detailed descriptions of the aquatic communities of WOC and WOL. A more detailed review of the nonradiological studies on aquatic ecology of the watershed is presented in Loar et al. (1981a). 


\section{1 .4 Synoptic Survey, Summer 1985}

A synoptic survey was conducted in August and September 1985 to (1) update results obtained in the comprehensive 1979-80 survey and (2) assist in identification of sampling sites to be included in BMAP as required by the NPDES permit for ORNL. This preliminary characterization included both instream sampling of biota (benthic invertebrates and $\mathrm{fish}$ ) and ambient toxicity testing at 12-15 sites in WOC watershed above WOL. All sampling, laboratory analyses, and data interpretation were conducted by staff in the Environmental Sciences Division (ESD) at ORNL.

\subsubsection{Benthic Invertebrate Survey}

Triplicate bottom samples were collected with a $0.09-\mathrm{m}^{2}$

Surber sampler on August 19-20, 1985, from selected riffle areas at each of 12 sites located on WOC ( 6 sites) and several tributaries, including MB ( 3 sites), NWT, First Creek, and Fifth Creek (Fig. 2). In the laboratory, benthic organisms were separated from debris in white enamel pans and idencified to genus, wherever possible. From these results, numerical abundance and the Shannon-Weiner diversity index were computed.

As observed in previous studies of the benthos in WOC (Krumholz 1954b; B. G. Blaylock, Oak Ridge National Laboratory, unpublished data, as reported in Loar et al. 1981a; Loar et al. 1981a), species richness (as represented by the mean number of taxa per sample and the total number of taxa per site) and species diversity were highest at the reference site [White Oak Creek kilometer (WCK) 6.8] located above ORNL and north of Bethel Valley Road (Table 1). Although the benthic fauna was numerically dominated by dipterans (328) and the snail, Goniobasis (238), the insect orders Plecoptera (stoneflies), Ephemeroptera (mayflies), and Tricoptera (caddisflies) were well represented (Table 2), making up 168,88 , and 38 of the total numbers, respectively. Compared with the undisturbed community at WCK 6.8 , both density and species richness were substantially lower at all sites on WOC south of Bethel Valley Road. Species diversity $\left(\mathrm{H}^{\prime}\right)$ was also considerably 


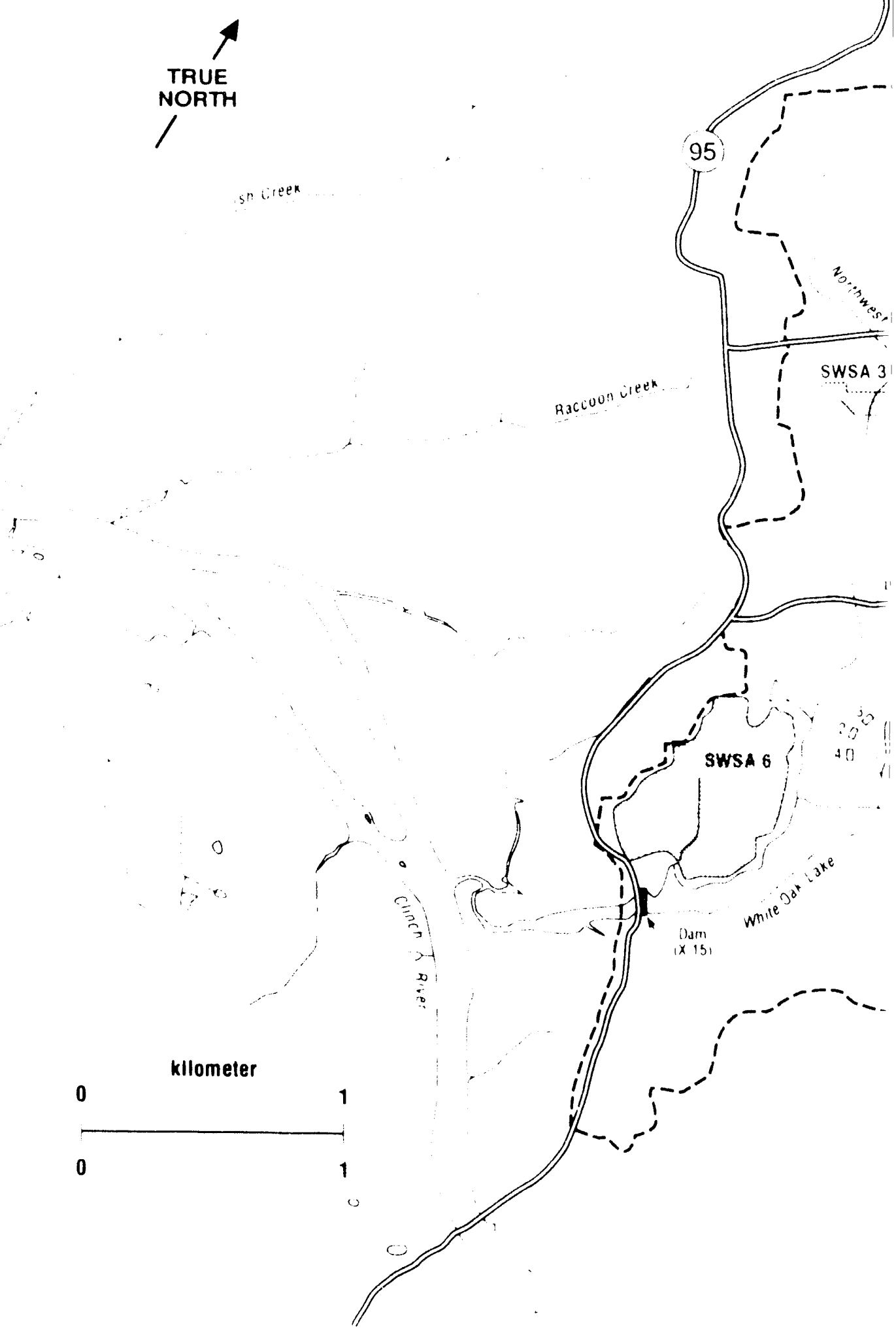

Fig. 2. Location of the 12 sites included in the synoptic be Pollutant Discharge Elimination System sites on Melton Branch (X13 disposalistorage areas. FCK = First Creek kilometer; FFK = Fifth Treatment Plant; SWSA = solid radioactive waste disposal/storage a 

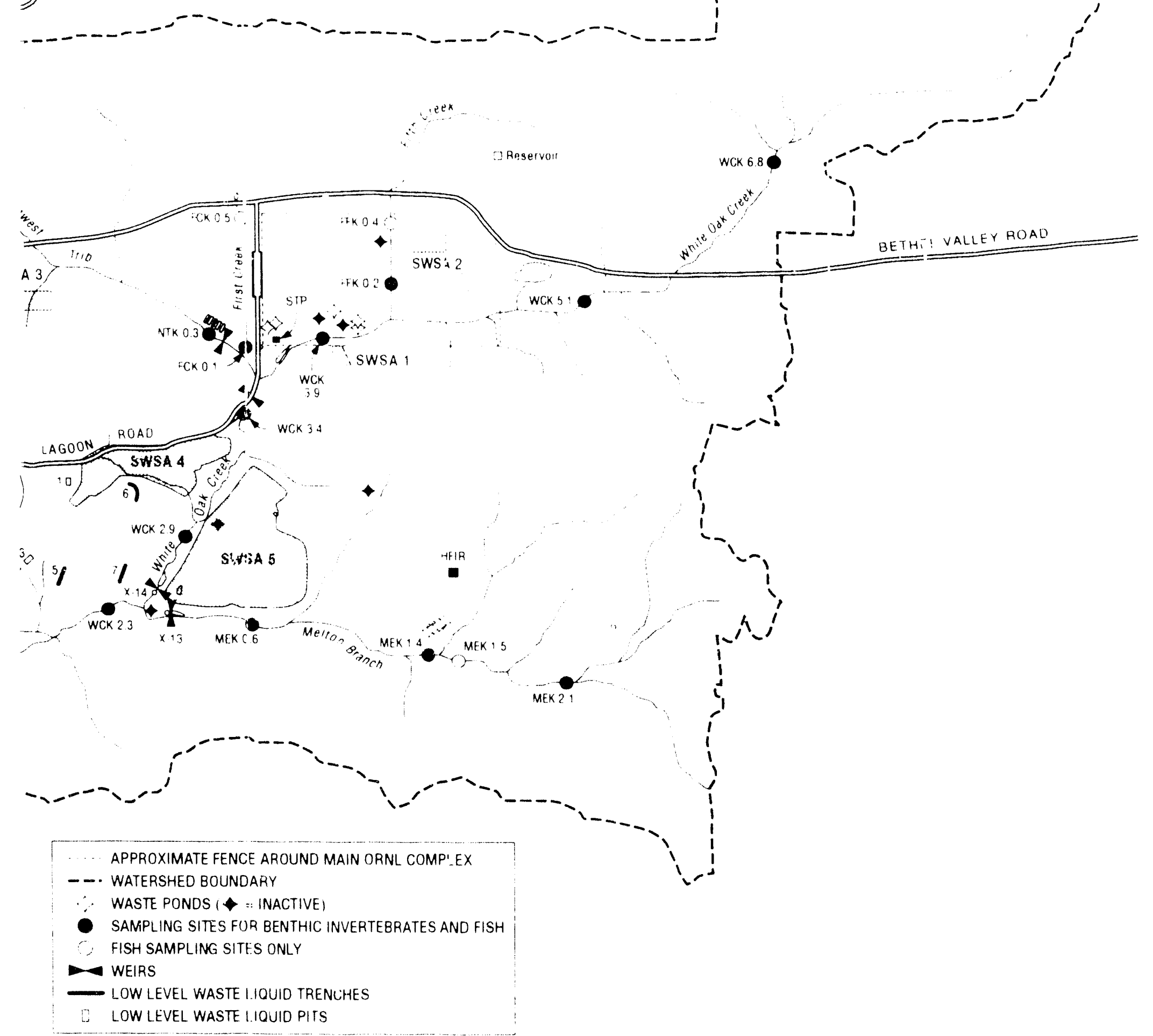

benthic and fish surveys conducted in August-September 1985 in white Oak Creek watershed; National 13), Thite Oak Creek (X14), and White Oak Dam (X15); and liquid and solid radioactive waste h Creek kilometer; HFIR = High Flux Isotope Reactor; MEK = Melton Branch kilometer; STP = Sewage area; $W C K=$ White Oak Creek kilometer. 
Table 1. Mean density (standard error indicated parenthetically), mean number of taxa (range indicated parenthetically), total number of taxa per site, and mean diversity (standard error indicated parenthetically) of benthic invertebrates in white Oak Creek watershed, August 19-20, $1985^{\circ}$

\begin{tabular}{|c|c|c|c|c|}
\hline $\begin{array}{l}\text { Sampling } \\
\text { site }^{\text {b }}\end{array}$ & $\begin{array}{l}\text { Mean density } \\
\left(\text { no. } / 0.1 \mathrm{~m}^{2}\right)\end{array}$ & $\begin{array}{l}\text { Mean number of } \\
\text { taxa per sample }\end{array}$ & $\begin{array}{l}\text { Number of taxa } \\
\text { at site }\end{array}$ & $\begin{array}{c}\text { Mean species } \\
\text { diversity } \\
\left(\mathrm{H}^{\prime}\right)\end{array}$ \\
\hline FCK $0 . ?$ & $\begin{array}{l}354.5 \\
(78.7)\end{array}$ & $\begin{array}{l}13.7 \\
(12-15)\end{array}$ & 23 & $\begin{array}{l}0.53 \\
(0.03)\end{array}$ \\
\hline FFK 0.2 & $\begin{array}{l}17.2 \\
(3.7)\end{array}$ & $\begin{array}{l}9.7 \\
(8-13)\end{array}$ & 22 & $\begin{array}{l}0.92 \\
(0.06)\end{array}$ \\
\hline MEK 0.6 & $\begin{array}{l}27.3 \\
(9.3)\end{array}$ & $\begin{array}{l}10.6 \\
(8-13)\end{array}$ & 19 & $\begin{array}{l}0.90 \\
(0.10)\end{array}$ \\
\hline MEK 1.4 & $\begin{array}{l}37.0 \\
(12.8)\end{array}$ & $\begin{array}{l}15.7 \\
(9-25)\end{array}$ & 31 & $\begin{array}{l}1.06 \\
(0.12)\end{array}$ \\
\hline MEK 2.1 & $\begin{array}{l}141.7 \\
(56.8)\end{array}$ & $\begin{array}{l}24.7 \\
(23-27)\end{array}$ & 44 & $\begin{array}{l}1.11 \\
(0.06)\end{array}$ \\
\hline NTK 0.3 & $\begin{array}{l}65.3 \\
(24.6)\end{array}$ & $\begin{array}{l}14.0 \\
(8-24)\end{array}$ & 28 & $\begin{array}{l}0.75 \\
(0.10)\end{array}$ \\
\hline WCK 2.3 & $\begin{array}{l}79.7 \\
(14.0)\end{array}$ & $\begin{array}{l}8.7 \\
(6-11)\end{array}$ & 17 & $\begin{array}{l}0.49 \\
(0.13)\end{array}$ \\
\hline WCK 2.9 & $\begin{array}{l}31.2 \\
(15.2)\end{array}$ & $\begin{array}{l}8.3 \\
(5-12)\end{array}$ & 17 & $\begin{array}{l}0.70 \\
(0.07)\end{array}$ \\
\hline WCK 3.4 & $\begin{array}{l}66.7 \\
(30.6)\end{array}$ & $\begin{array}{l}14.7 \\
(9-19)\end{array}$ & 26 & $\begin{array}{l}0.92 \\
(0.06)\end{array}$ \\
\hline WCK 3.9 & $\begin{array}{l}14.0 \\
(4.35)\end{array}$ & $\begin{array}{l}8.3 \\
(3-1 i)\end{array}$ & 17 & $\begin{array}{l}0.79 \\
(0.19)\end{array}$ \\
\hline WCK 5.1 & $\begin{array}{l}89.2 \\
(13.7)\end{array}$ & $\begin{array}{l}14.0 \\
(11-19)\end{array}$ & 23 & $\begin{array}{l}0.75 \\
(0.09)\end{array}$ \\
\hline WCK 6.8 & $\begin{array}{l}448.5 \\
(129.4)\end{array}$ & $\begin{array}{l}36.0 \\
(3.1-43)\end{array}$ & 56 & $\begin{array}{l}1.08 \\
(0.08)\end{array}$ \\
\hline
\end{tabular}
${ }^{a}$ Values are based on three Surber samples taken at random from riffle areas at each site.

${ }^{b}$ FCK 0.1 = First Creek kilometer 0.1 or $0.1 \mathrm{~km}$ above major confluence; $\mathrm{FFK}=$ Fifth Creek kilometer; $\mathrm{MEK}=$ Melton Branch kilometer; NTK $=$ Northwest Tributary kilometer; WCK $=$ White Oak Creek kilometer . 


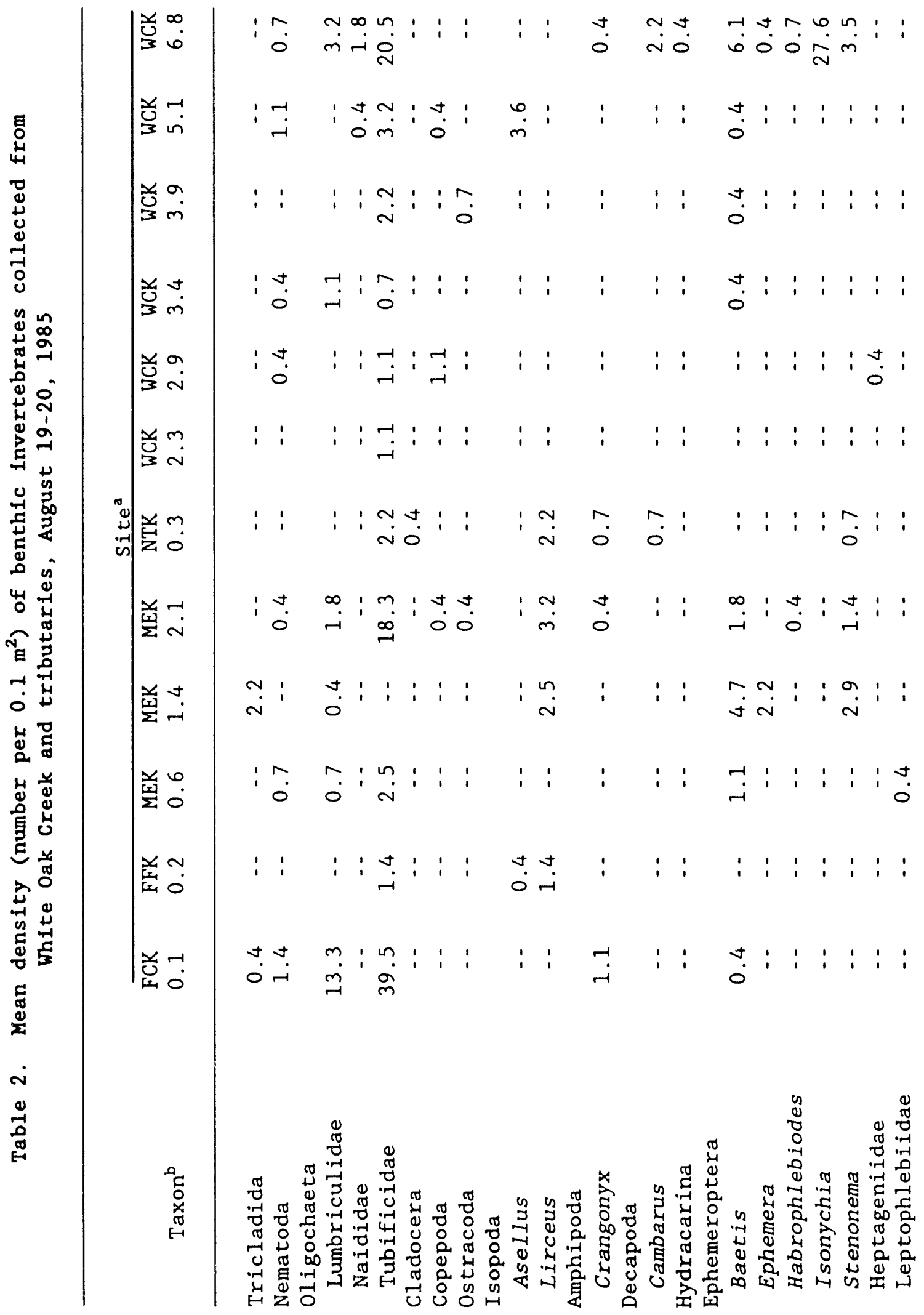




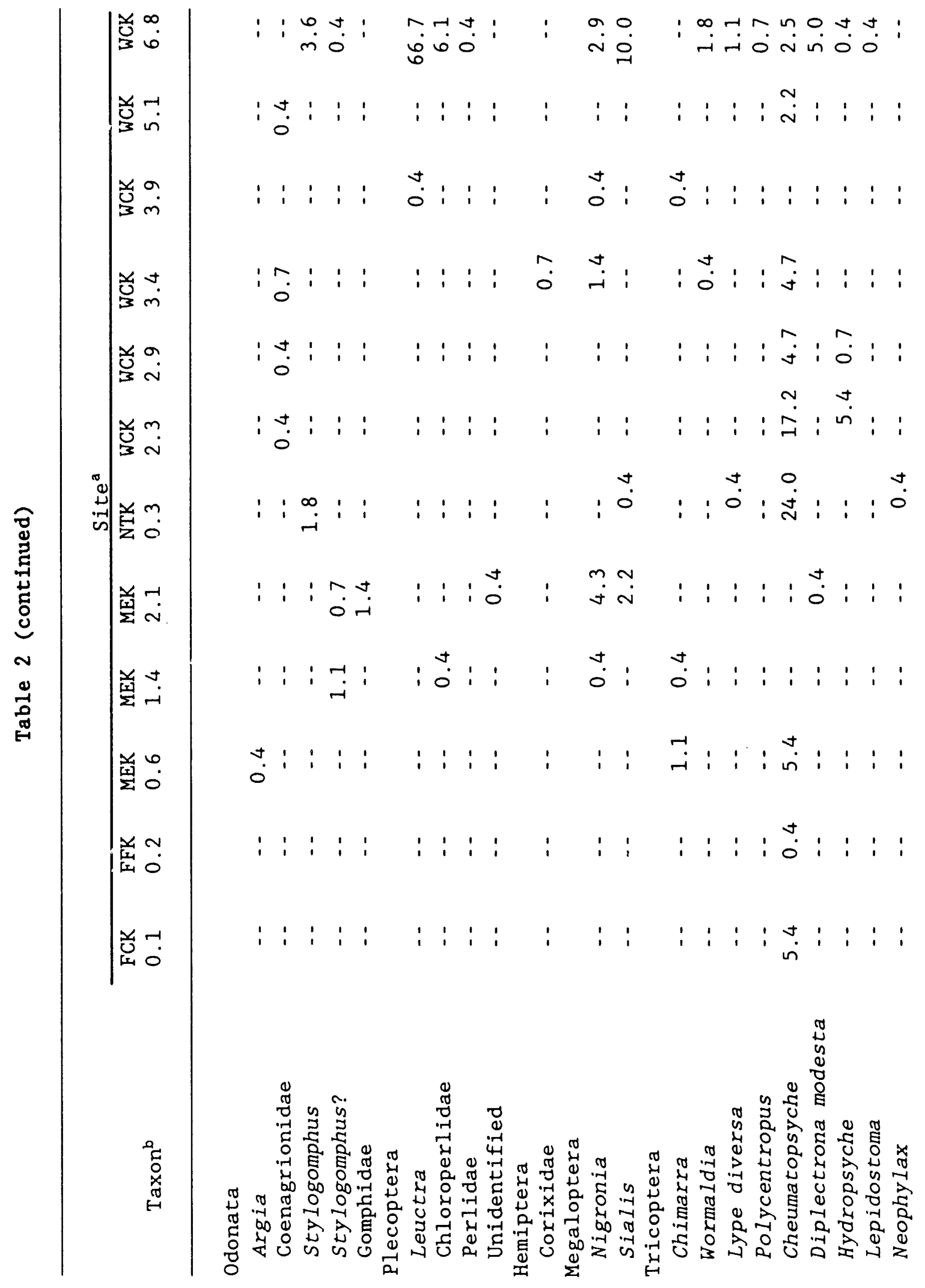




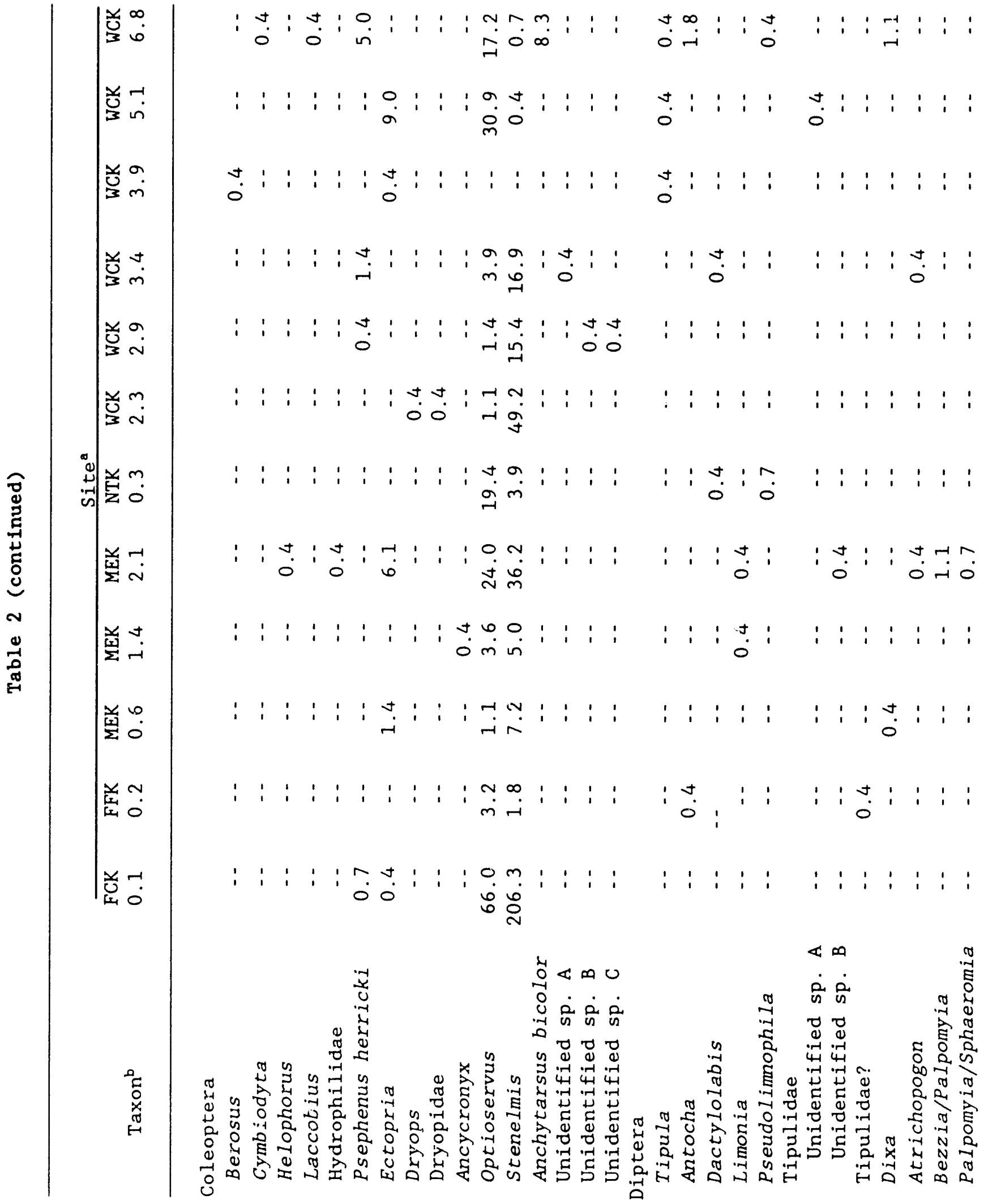




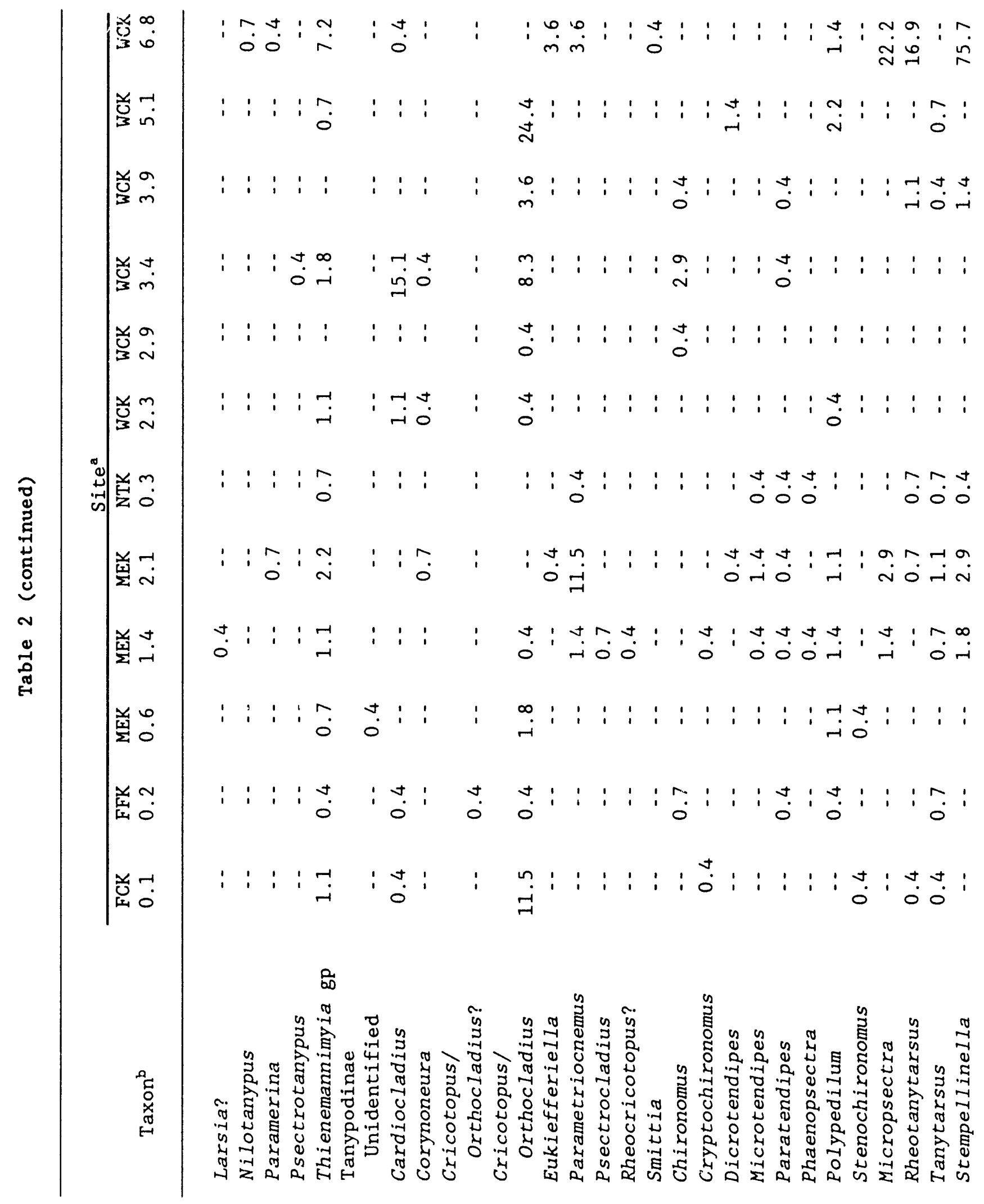




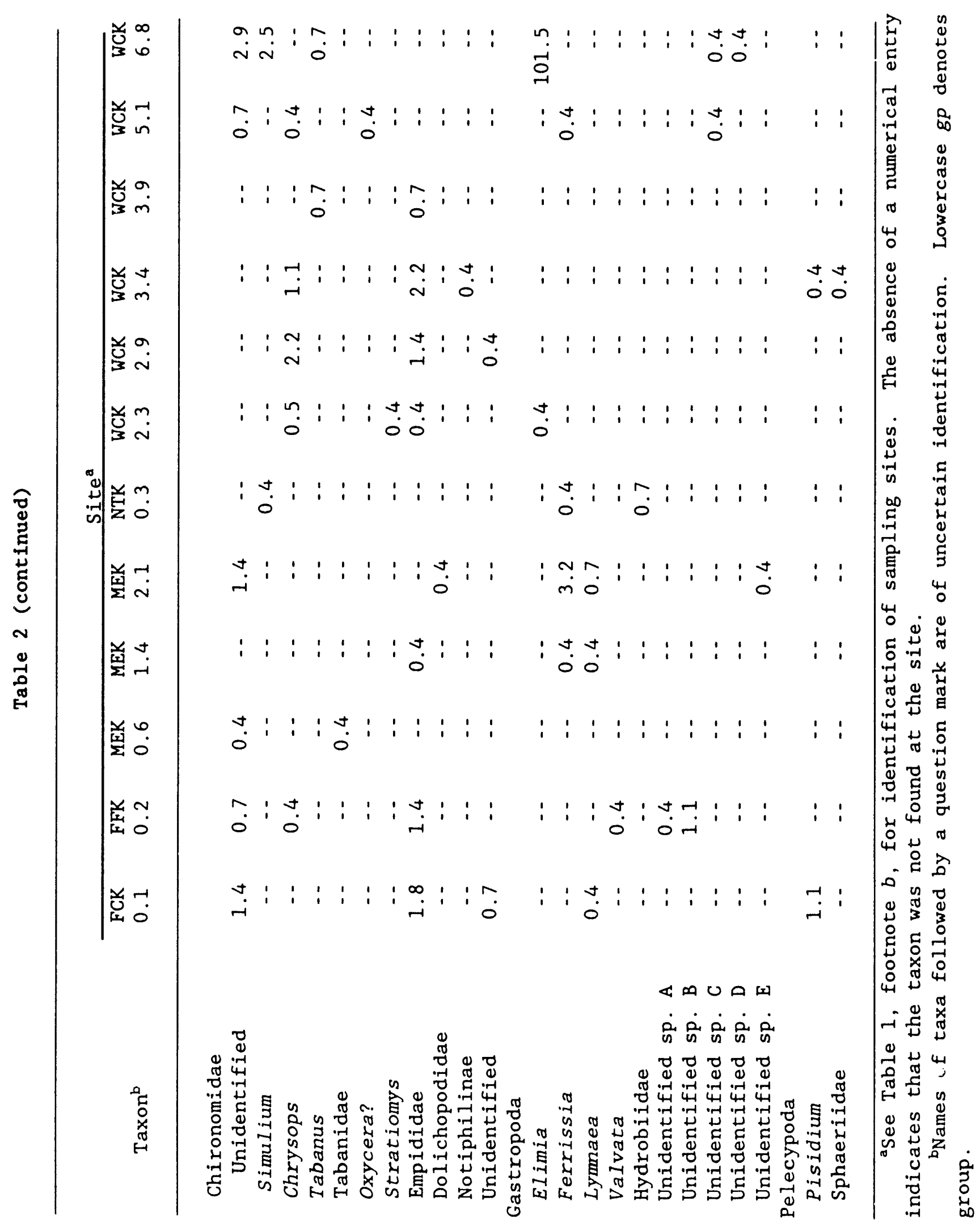


lower at these sites than at WCK 6.8, with the exception of WCK 3.4 , where the relatively high diversity can be attributed to the even distribution of individuals among the few species present. Further evidence of a significant impact on the benthic communities downstream of WCK 6.8 is the substantial reduction in most major taxa; in many cases, major taxa were totally absent. Particularly striking was the total absence of stoneflies, snails (Goniobasis), most mayfly and caddisfly taxa, and several dipterans (e.g., Zavrelia) from WCK 5.1 (Table 2); the dominant taxa at this site were the elmid beetle Optioservus (358) and chironomids (348).

Unlike previous studies in which chironomids were found to be the dominant group in WOC below ORNL (Krumholz 1954b and B. G. Blaylock, Oak Ridge National Laboratory, unpublished data, as reported in Loar et al. 1981a; Loar et al. 1981a), the dominant taxon found in the present survey was the elmid beetle, Stenelmis; only at WCK 3.4 were chironomids the dominant group (448). A considerable increase in hydropsychid caddisflies at the downstream site (WCK 2.3) was observed in the 1985 survey. The only other study reporting the occurrence of caddisflies below ORNL was the 1979-80 survey of Loar et al. (1981a), in which the hydropsychid, Cheumatopsyche, was found at WCK 2.7 in very low densities (four individuals per square meter; J. M. Loar, Oak Ridge National Laboratory, unpublished data). The large increase in hydropsychids since 1980 could be the result of an increase in their food supply and/or an improvement in water quality. For example, construction of new weirs and/or modification of existing weirs on WOC and $M B$ may have enhanced primary production in the small impoundments just above the weirs and provided a food source for downstream filterfeeding species like Cheumatopsyche.

Results of the 1985 survey indicated that a highly diverse benthic fauna inhabits $M B$ above the tributary receiving discharges from the HFIR (Fig. 2), whereas the two sites below the HFIR were adversely impacted (Table 1). Similar results were obtained by B. G. Blaylock, Oak Ridge National Laboratory (unpublished data, as reported in Loar et al. 1981a) in a 1974-75 survey. The high $\mathrm{H}^{\prime}$ value at station Melton Branch kilometer (MEK) 1.4 , which was located only $30 \mathrm{~m}$ below the confluence 
with the HFIR tributary (Fig. 2), was due to a lack of dominance by any one taxon. The collection of a relatively large number of taxa at this site could be the result of invertebrate drift from unimpacted upstream areas. Density and species richness declined considerably at the lowest station on MB (MEK 0.6 ), but $\mathrm{H}^{\prime}$ remained relatively high, due again to the lack of dominance hy any one taxon. Five years ago, the fauna at MEK 0.6 was dominated by chironomids ( $80 \%)$ and elmid beetles (11\%); mayfly densities were low and no caddisflies were found (Loar et al. 1981a). Although mayfly densities remained low, caddisflies in the present survey composed 248 of the total organisms collected at this site. These results suggest that a moderate shift in species composition has occurred since 1980 , but an adverse impact on the benthic community in lower $M B$ still exists.

The benthic invertebrate comnunity of NWT [Northwest Tributary kilometer (NTK) 0.3] appears somewhat impacted (Table 1). The fauna at this site was dominated by elmid beetles (368) and Cheumatopsyche (378); chironomids constituted only 68 of the benthos (Table 2). Based on limited sampling conducted in 1974-75, a benthic community dominated by Cheumatopsyche (578) and chironomids (258), and to a lesser extent by elmid beetles ( 88 ), was ok 2 rved (B. G. Blaylock, Oak Ridge National Laboratory, unpublished data). Mayfly densities were relatively low, and stoneflies were absent in both studies. Although sampling was limited in the earlier survey, the results of the two studies seem to indicate that no major change has occurred in the benthic community of NWT between 1974 and 1985 .

The low species richness and diversity observed in First Creek [First Creek kilometer (FCK) 0.1 ] are indicative of environmental stress (Table 1). This site was dominated by elmid beetles (778) and oligochaetes (158) (Table 2). Although total density was very high, very low numbers of mayflies and caddisflies were collected, and stoneflies were absent.

Fifth Creek [Fifth Creek kilometer (FFK) 0.2] was one of the most impacted sites included in the 1985 survey (Table 1). Density and species richness were low, and species diversity was high due to a lack 
of dominance by any taxa. The most abundant taxa included elmid beetles (298) and chironomids (268).

\subsubsection{Fish Survey}

Fish sampling was conducted August 14-September 18, 1985, by using one or two (depending upon the width of the stream) Smith-Root Mode1 15A backpack electrofishers. Sampling was conducted near the 12 sites included in the benthos survey and at additional upstream control sites on Fifth Creek (FFK 0.4), First Creek (FCK 0.5), and Melton Branch (MEK 1.5) (Fig. 2). Densities of each species were calculated from population estimates based on the removal method (Carle and Strub 1978) with three consecutive passes at each site.

Fish densities in wOC ranged from less than 0.1 individuals per square meter at station WCK 3.9 near the main ORNL complex to 10.1 individuals per square meter at WCK 5.1 just east of ORNL (Table 3 ). Densities at the three sites below ORNL were low (less than 0.30 individuals per square meter), and, with the exception of station WCK 2.3, species richness was also low. Whereas few species typically inhabit the small undisturbed headwater streams on ORR, such as the upper reaches of $M B$, WOC, and First Creek (Table 3), species richness generally increases downstream, due, in part, to increased streamflow and greater habitat diversity. Consequently, the low abundance and number of species in lower WOC are indicative of an impacted community. The magnitude of the impacts in 1985, however, was less than that observed in a 1979-80 survey, in which no fish were found at stations MEK 0.6 and WCK 2.7 (Loar et al. 1981a). Finally, the very high density observed at station WCK 5.1 is unusual and exceeds the densities typically found in streams of this size by a factor of 2 or 3 (e.g., MB, First Creek, and upper WOC, Table 3; Grassy Creek, J. M. Loar, Oak Ridge National Laboratory, unpublished data). Such high densities may reflect (1) transitory shifts in distribution resulting from adverse conditions not far downstream (Fig. 2) or (2) increase in food availability (periphyton production). For example, densities of the central stoneroller, a periphyton grazer, increased from 0.03 to 4.28 individuals per square meter between sites WCK 6.8 and WCK 5.1 , respectively. 


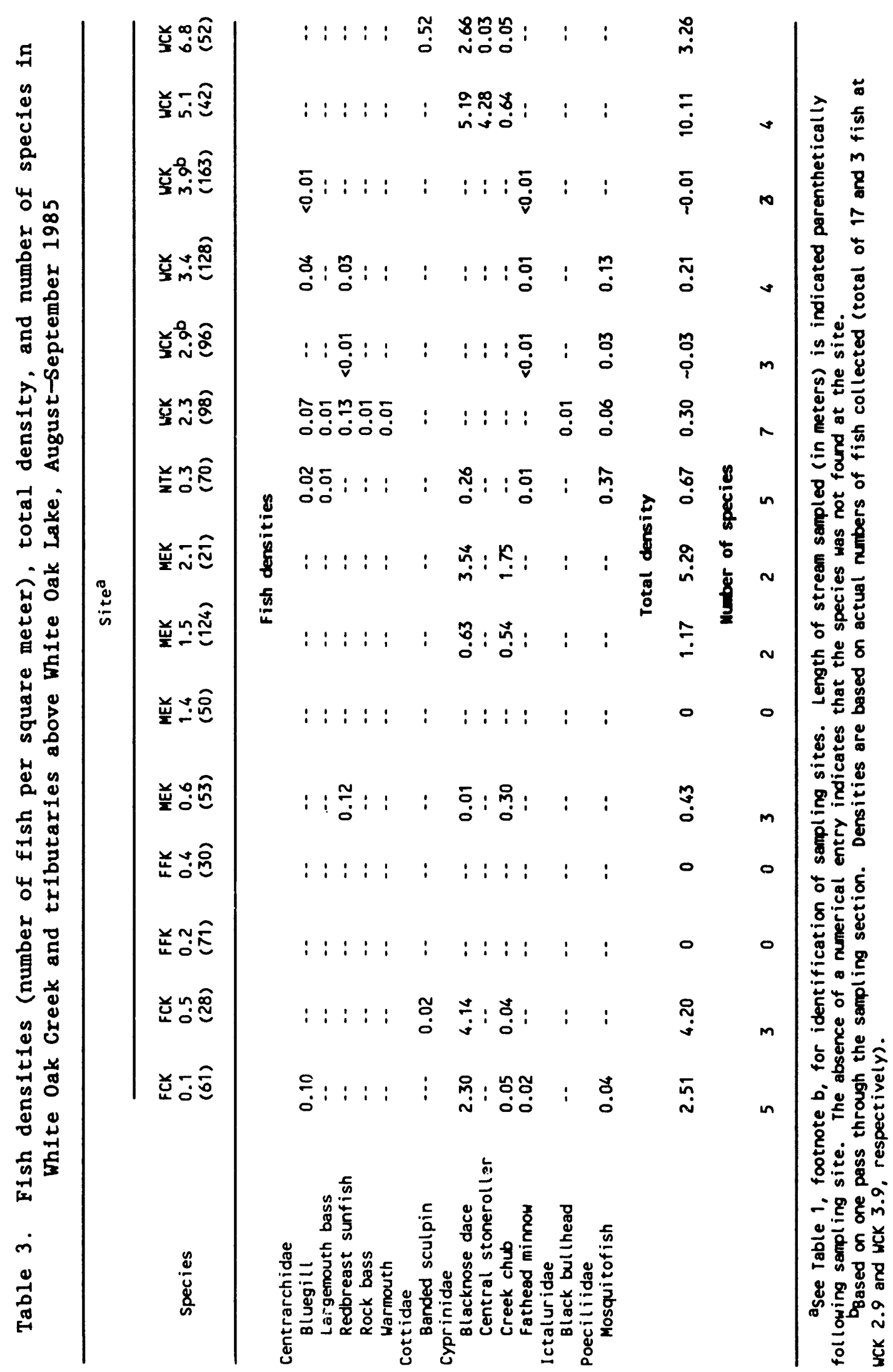


Adverse impacts were also observed on the fish communities in several tributaries of WOC, especially in Fifth Creek and lower MB. No fish were collected in Fifth Creek or in MB just below the confluence with a small tributary that receives effluents from the HFIR, including blowdown from the cooling towers. Water temperatures at this latter site (MEK 1.4 ) exceeded $33^{\circ} \mathrm{C}$ on the day of sampling; similar results were obtained in May 1985 at a water temperature of $36^{\circ} \mathrm{C}$ (G. F. Cada, Oak Ridge National Laboratory, unpublished data).

The synoptic ecological characterization conducted in 1985 identified several areas in the WOC watershed that appear to be significantly impacted by current operations at ORNL. These areas are Fifth Creek, lower MB below the HFIR, and WOC below ORNL, especially that reach of WOC adjacent to the ORNL complex. All three areas are within close proximity to blowdown discharges from cooling towers. The distribution of fish densities among sites was, with few exceptions, similar to that of benthos densities (Fig, 3). In WOC below ORNL, for example, the initial increase in density at WCK 3.4, followed by a decrease at WCK 2.9 below SWSA 4, was observed in both the benthos and fish surveys. The two surveys also provided evidence that the impacts on First Creek and Northwest Tributary are moderate in comparison with these other areas. The general similarity in the response of the benthic invertebrate and fish communities among the 12 sites suggests that either (1) the sources of impacts on the two communities are similar and each community responds independently of the other or (2) only the benthic community is directly impacted, but the impact is propagated via the food chain (e.g., reduced food availability) to the fish community. Additional studies are needed to identify the nature and source(s) of impact and its ecological effects.

\subsubsection{Ambient Toxicity Evaluation}

Toxicity tests were conducted to characterize conditions in WOC and in selected tributaries with respect to the toxicity of the ambient water to aquatic life. Chemical analysis has traditionally been used to characterize ambient water quality in streams receiving effluents. However, toxicity testing is a useful supplement or even a preferred 


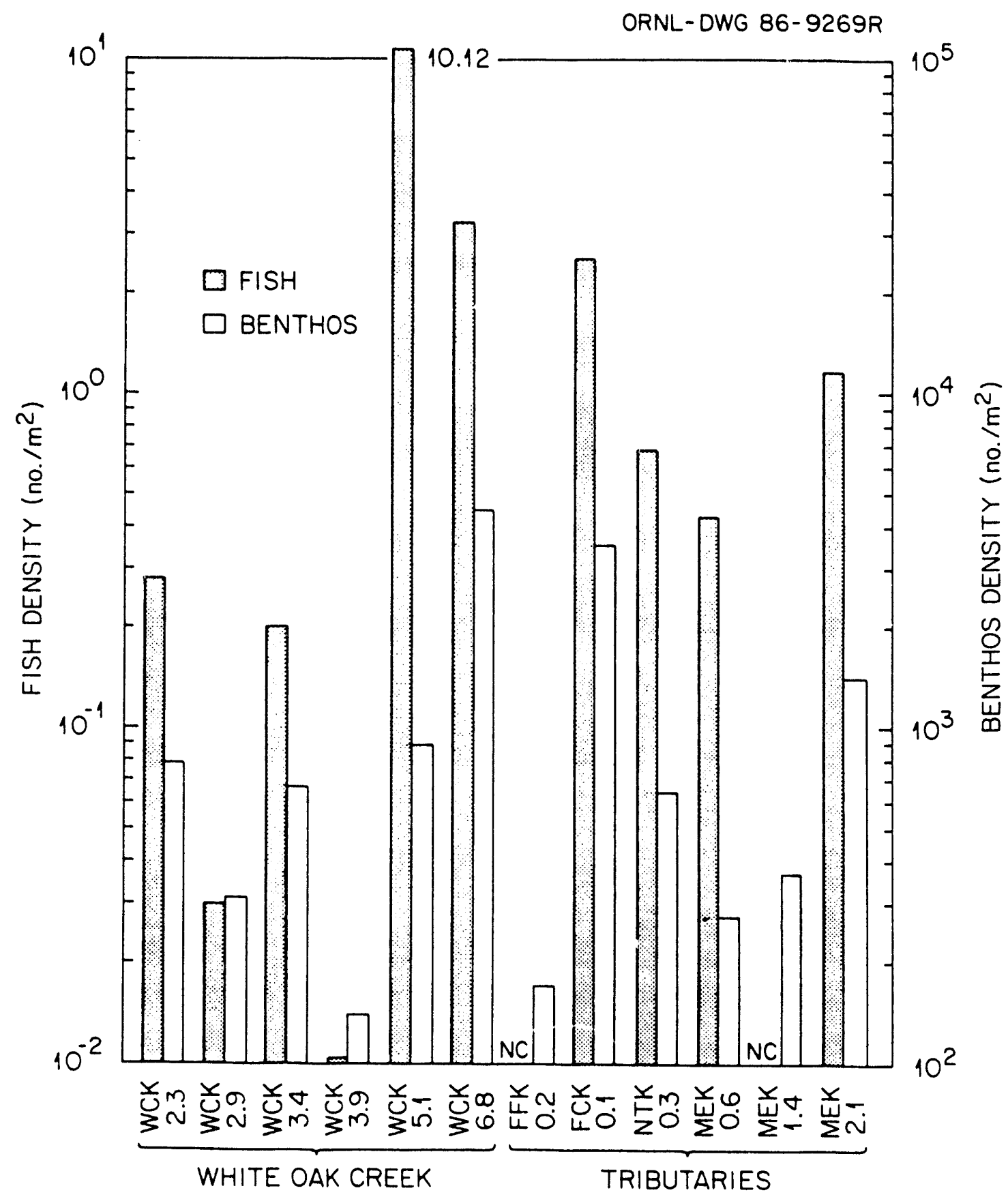

Fig. 3. Comparison of benthos and fish densities at 12 sites on Thite Oak Creek and selected tributaries (Fifth Creek, First Creek, Northwest Tributary, and Melton Branch). Note the different scales for benthos and fish. Sites are identified by the distance (in kilometers) upstream from a major confluence: White Oak Creek kilometer (WCK), Fifth Creek kilometer (FFK), First Creek kilometer (FCK), Northwest Tributary kilometer (NTK), and Melton Branch kilometer (MEK). Locations of sampling sites are shown in Fig. 2. NC = none collected. 
alternative to chemical analysis in many situations because (1) it is rapid and economical; (2) many chemical constituents of complex effluents are difficult to analyze; (3) some toxic constituents may be unsuspected and therefore not measured; (4) toxicological interactions among effluent constituents, and between those constituents and other components in the receiving water, are unpredictable; and (5) toxicity testing gives a direct indication of potential hazards to aquatic 1 ife. Indeed, EPA policy was revised in 1984 to encourage the incorporation of toxicity testing in effluent regulation and permitting, instead of--or in addition to--chemical analyses (EPA 1985b).

Toxicity tests were conducted on August $6-13$ and 21-28, 1985, and on February 20-27, 1986, using "short-chronic" test methods recently developed by EPA and others specifically for effluent monitoring and ambient toxicity testing (Peltier and Weber 1985). One method measures effects of substances on the survival and growth of the fathead minnow (Pimephales promelas) during the first $7 \mathrm{~d}$ after hatching. The second method measures effects on survival and reproduction of a crustacean zooplankter, Ceriodaphnia. These tests are the most sensitive short-term aquatic toxicity tests currently available.

In the initial test, water was collected from six sites on wOC from the headwaters north of Bethel Valley Road to a site above WOL (sites 1, $2,4,5,6$ and 7, as shown on Fig. 4) and from sites on First Creek (site 12), Fifth Creek (site 3), NWT (site 11), and MB (sites 8, 9, and 10). Fathead minnow larvae were placed in water from each site, and the water was replaced daily (from the original sample). Fish exposed to water from Fifth Creek and from White Oak Creek just below the confluence with Fifth Creek (sites 3 and 4, respectively) suffered high mortality the first night of the test. Water from the ten other sites did not appear to be toxic (i.e., survival exceeded 958). Conductivity, hardness, alkalinity, and $\mathrm{pH}$ values for sites 3 and 4 did not differ markedly from those of the other ten sites. The pattern of mortality over time suggested the presence of a volatile toxicant. Because of the presence of the Oak Ridge Research Reactor cooling tower on Fifth Creek, it was hypothesized that the cooling tower was discharging residual 


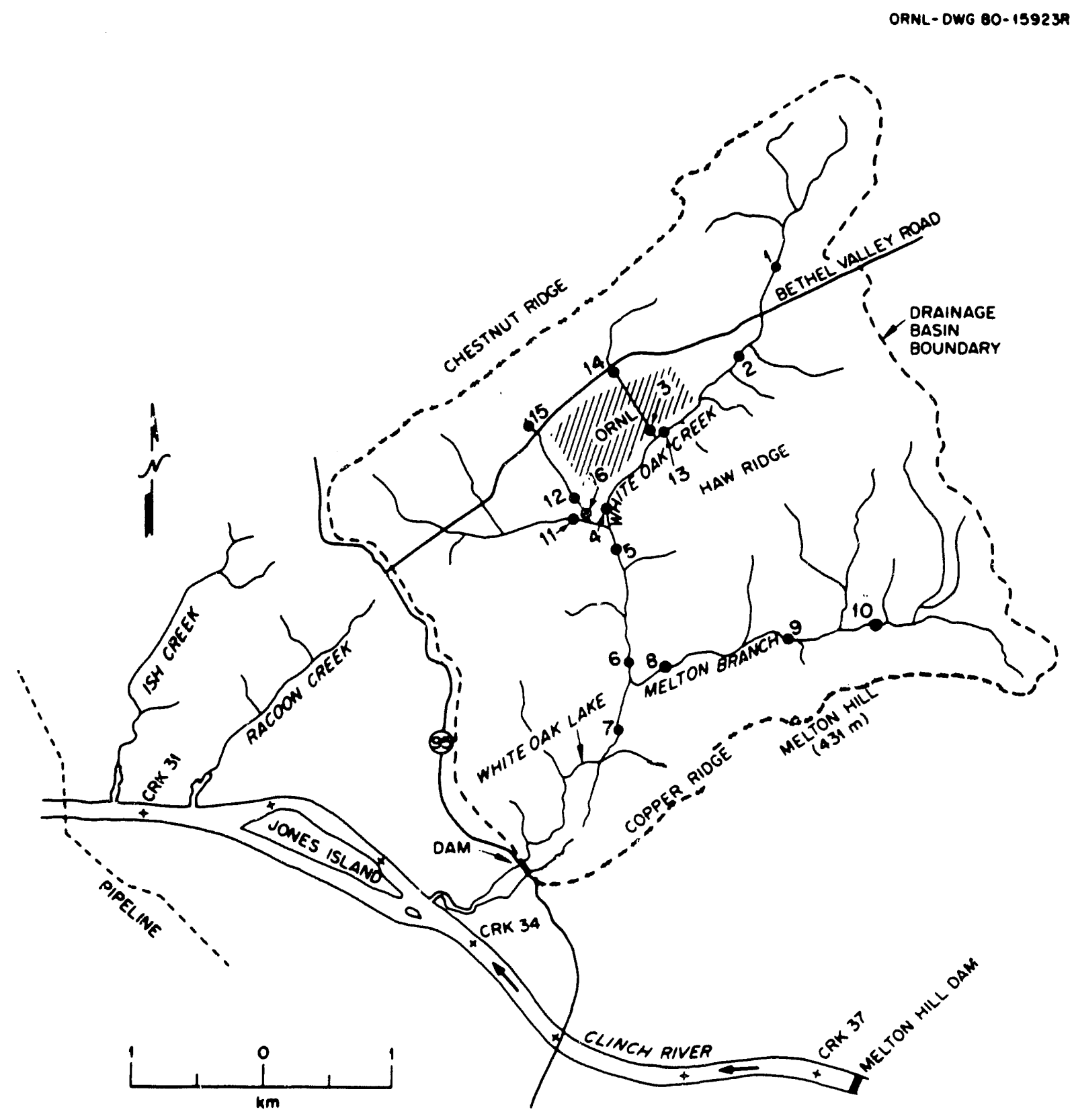

Fig. 4. Location of the 16 sites from which water was collected for toxicity tests. Sites $1,3,4,5$, and 6 were tested twice (August 6-13 and August 21-28, 1985); sites $2,7,8,9,10,11$, and 12 were tested once (August 6-13), as were sites 13 and 14 (on August 21-28, 1985). Sites 15 and 16 were tested once, with Ceriodaphnia, on February 20-27, 1986. $\mathrm{CRK}=$ Clinch River kilometer. 
chlorine or bromine. On August 9 , a level of $0.40 \mathrm{mg} / \mathrm{L}$ total residual haloger was measured in Fifth Creek; previous studies have shown this level to be above the lethal level for fish (see review by Mattice and Zittel 1976).

In the August 21-28 experiments, water from sites $1,3,4,5$, and 6 (and from two new sites: sites 13 and 14, Fig. 4) were tested with fathead minnow larvae; water from sites 3 and 4 was also tested with Ceriodaphnia. Water froin site 3 caused 108 mortality of fathead minnow larvae on 2. of the $7 \mathrm{~d}$ of the test (August 23 and 28), and fathead minnow larvae suffered complete mortality when tested with water collected from site 13 on August 25-28. The five other sites tested in this experiment (sites 1, 4, 5, 6, and 14) were nontoxic to fathead minnow larvae. Survival of Ceriodaphnia was 118 in water from site 13 and $0 z$ in water from site 3 after $3 \mathrm{~d}$. Interpretation of data from the Ceriodaphnia test was confounded by the fact that survival of Ceriodaphnia in control water was only 808. Daily chemical analyses of the water collected for these experiments showed that alkalinity values ranged from 60 to $140 \mathrm{mg} / \mathrm{L}$ as $\mathrm{CaCO}_{3}$; hardness values, from 82 to $164 \mathrm{mg} / \mathrm{L}$ as $\mathrm{CaCO}_{3} ; \mathrm{pH}$ values, from 7.19 to 8.03 ; and conductivity, from 104 to $600 \mu \mathrm{s} / \mathrm{cm}$. Chlorine was implicated as a possible intermittent contributor to toxicity in water from sites 3 and 13: over the 7 -d test period, daily concentrations (mean \pm 1 s.d.) of total residual chlorine for control water and for water from sites 3 and 13 averaged $0.047 \pm$ $0.014,0.101 \pm 0.071$, and $0.077 \pm 0.063 \mathrm{ppm}$, respectively.

Measurements of free and total chlorine in water from 12 sites on WOC and from 11 sices in tributaries to this stream were also made on September 9, 12, and 16, 1985. Results of these measurements showed that wOC sites downstream from site wOC 2 (Fig. 5) had higher total chlorine concentrations $(0.178 \pm 0.169$, mean \pm 1 s.d., $n=23$ across all dates) than did more-upstream sites (undetectable at four sites on all three dates). Water from five sites in lower Fifth Creek (sites $\mathrm{T} 1$, T1B, T1C, T1D, and T1E; Fig. 5) alss contained elevated levels of total chlorine $(0.200 \pm 0.122 \mathrm{ppm}$, mean $\pm 1 \mathrm{s.d} ., n=15$ across all dates) compared with two sites farther upstream $(0.005 \pm 0.005 \mathrm{ppm}$, mean \pm 1 s.d., $n=6$ across all dates). Total chlorine in NWT (Fig. 5) water 


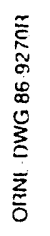

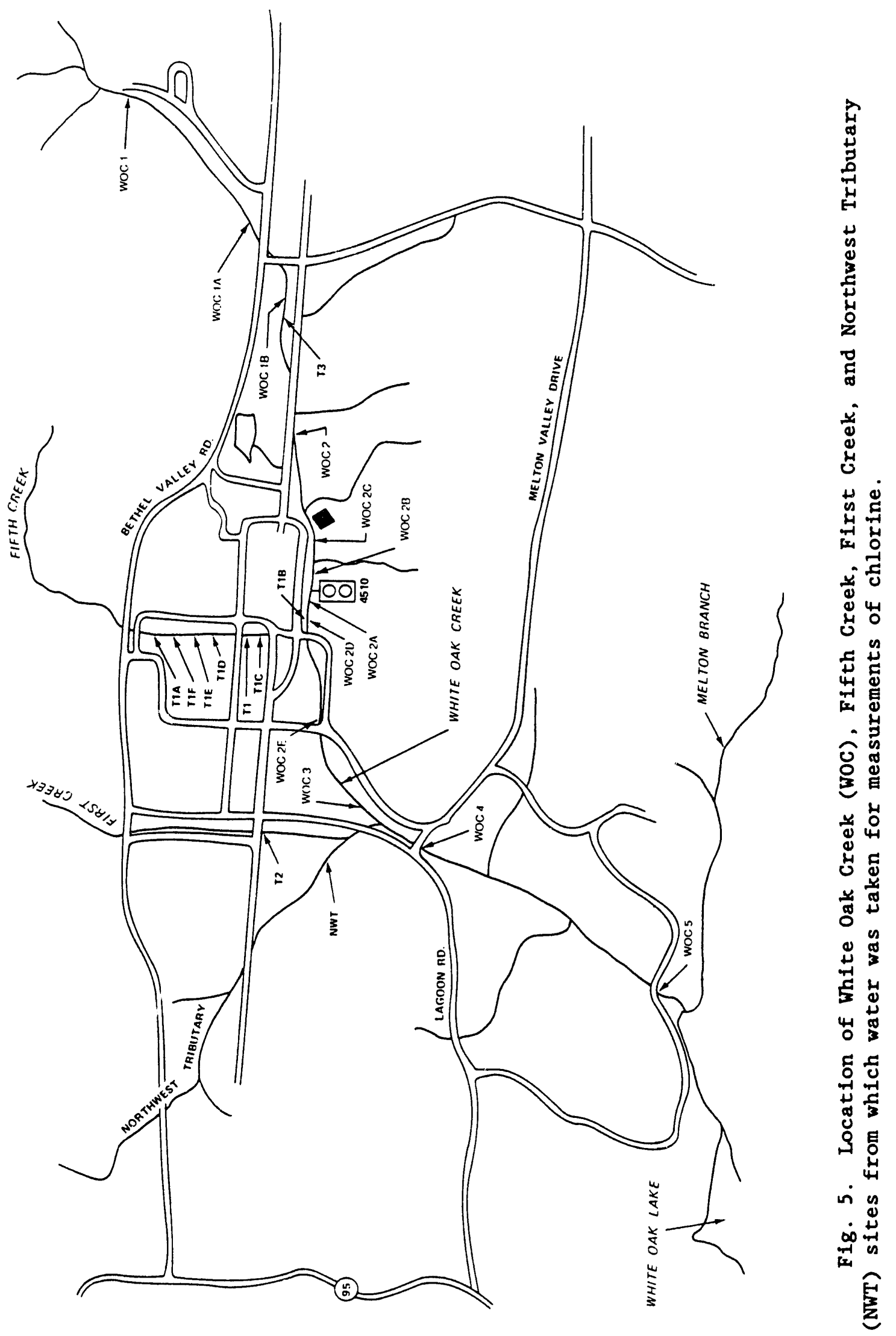


during September 12-16 was undetectable, whereas total chlorine in lower First Creek (site T2) was $0.13 \pm 0.01 \mathrm{ppm}$ (mean $\pm 1 \mathrm{s.d.}$ ) for the three dates.

Daily grab samples of water from sites 15 and 16 (Fig. 4) were tested with Ceriodaphnia on February 20-27, 1986. Although this test was flawed by erratic mortality and low fecundity of animals in the controls, results suggested that water from this tributary to wOC was not toxic. Mean numbers of offspring per female raised in control water and in water from upper and lower First Creek sites were 10.7 \pm 8.1 , $8.3 \pm 6.4$, and $8.9 \pm 4.7$ (mean $\pm 1 \mathrm{s.d}$.), respectively. Summary statistics for daily measurements of $\mathrm{pH}$, conductivity, alkalinity, and hardness during this test are shown in Table 4.

Based on the results of these tests, it was concluded that water in lower Fifth Creek and at some sites on WOC (1) is toxic to minnow larvae and to Ceriodaphnia and (2) contains relatively high levels of residual halogen (more than $0.1 \mathrm{mg} / \mathrm{L}$ ) at some times and places. Results of these toxicity tests were confirmed by the instream surveys, which revealed very low benthos densities and very few or no fish near the same sites (Fig. 3). Furthermore, cooling tower blowdown is probably responsible for some, but not all, of the residual halogen detected in Fifth Creek and WOC. The correlation between measured total residual halogen in the water and measured toxicity of the water to the test organisms was not exact, suggesting that other toxicants may also be present in the water.

\subsection{TERRESTRIAL ECOLOGY}

\subsubsection{Radioecology}

The principal areas where terrestrial radioecological studies have been conducted in the watershed include (1) WOL bed; (2) seepage areas east and west of low-level waste (LLW) seepage pits 2, 3, and 4;

(3) cobalt seep area east of Trench 7; and (4) WOC floodplain south of SWSA 4 (see Fig. 2). Previous studies conducted in wOL bed showed that soils in the upper lake bed exhibited significantly elevated concentrations of ${ }^{137} \mathrm{Cs},{ }^{60} \mathrm{Co},{ }^{106} \mathrm{Ru}$, stable $\mathrm{Ca}, \mathrm{Na}$, and $\mathrm{P}$ (Auerbach 1959). Effluents carrying radionuclides entered the upper lake bed from 
Table 4. Mean values for chemical parameters measured in upstream (just north of Bethel Valley Road) and downstream (just upstream from the confluence of First Creek with Northwest Tributary) sites of First Creek, February 20-27, 1986"

\begin{tabular}{lcccc}
\hline Sampling site & $\mathrm{pH}$ & Conductivity $^{\mathrm{b}}$ & Alkalinity $^{\mathrm{c}}$ & Hardness $^{\mathrm{d}}$ \\
\hline $\begin{array}{l}\text { Upper Fj.rst } \\
\text { Creek }\end{array}$ & 7.84 & 138.0 & 81.7 & 96.4 \\
$\begin{array}{l}\text { Lower First } \\
\text { Creek }\end{array}$ & $(2.3)$ & $(12.7)$ & $(13.4)$ & $(10.9)$ \\
& 8.00 & 202.0 & 105.5 & 123.0 \\
& $(1.5)$ & $(16.3)$ & $(17.2)$ & $(8.7)$ \\
\hline
\end{tabular}

asampling sites correspond to sites 15 and 16 in Fig. 4. Numbers in parentheses show coefficient of variation associated with day-by-day differences.

${ }^{b}$ In microsiemens per centimeter, corrected to $20^{\circ} \mathrm{C}$.

'In milligrams per liter as $\mathrm{CaCO}_{3}$, titrated to an endpoint of $\mathrm{pH}=4.50$.

dIn milligrams per 1 iter as $\mathrm{CaCO}_{3}$. 
the east seepage area, which drained a portion of the LLW seepage pit area. Strontium-90, also present in elevated concentrations, showed considerable decline in the lower lake bed soils ( -508 loss due to transport from soil in 1.25 years) from 1956 to 1958; however, upper lake bed soils were losing ${ }^{90} \mathrm{Sr}$ at a slower rate. The estimated ${ }^{90} \mathrm{Sr}$ inventory in soil for the 16.2-ha vegetated portion of the lake was $11.7 \mathrm{Ci}$ in 1958.

Radioactive waste disposal activities in the ORNL pit and trench area have provided contaminated sites for past radioecological terrestrial research. From June 1952 through December 1959, -432,000 Ci of beta activity was pumped into LLW pits 2,3 , and 4 on the ORNL burial grounds north of the WOL bed (Cowser et al. 1960). The inventory of the LLW pit system included $-239 \mathrm{kCi}{ }^{103,106} \mathrm{Ru}, 165 \mathrm{kCi}{ }^{134,137} \mathrm{Cs}, 71 \mathrm{kCi}$ transuranic elements, and $41 \mathrm{kCi}{ }^{89,90} \mathrm{Sr}$. An estimated $160 \mathrm{Ci}{ }^{106} \mathrm{Ru}$ in 1958 plus an additional $1300 \mathrm{Ci}$ in 1959 seeped from these LLW pits onto the lake bed. About a third of the ${ }^{106} \mathrm{Ru}$ that was discharged to the lake bed in 1959 moved to the Clinch River (Cowser et al. 1960). In early 1962, the estimated ${ }^{106} \mathrm{Ru}$ in the lake bed soils was $2200 \mathrm{Ci}$ (Lomenick et al. 1962). Trench 5, located to the east of LLW pits 2, 3, and 4, first received liquid wastes in June 1960 and eventually received wastes totaling more than $300,000 \mathrm{Ci}$ before being covered and capped in 1966 (01sen et a1. 1983).

Two principal seepage areas where radionuclides had migrated from the waste pits were identified in early radioecology studies associated with the LLW disposal operations (Auerbach 1957). The east seepage area was located in a ravine east of pits 2,3 , and 4 . The west seepage area was located in a ravine immediately west of pits 2,3 , and 4, and west of Trench 5 .

Trench 7 was used for the disposal of intermediate-level liquid radioactive wastes from 1962 to 1966 and received $-270 \mathrm{kCi}$ of radioactivity including fission products, activation products, actinide, and transuranic elements (01sen et al. 1983). A seepage area located east of Trench 7 near well T7-13 is known locally as the "cobalt seep." Concentrations of ${ }^{60} \mathrm{Co}$ in the gravels of the stream draining this seep exceed 10,000 dpm/g (Spalding and Cerling 1979). 
The WOC floodplain south of SWSA 4 was contaminated in 1944 by fission products and transuranic elements when the site served as a temporary impoundment for liquid radioactive effluents from ORNL (Oakes et a1. 1982a). The impoundment was drained in late 1944, and the total radioactivity in this area in late 1.946 was estimated at $68 \mathrm{Ci}$. An early successional forest developed on the -3 -ha site in the 30 -year period following drainage of the impoundment. Concentrations of radiocesium and plutonium in floodplain soils are elevated near the old impoundment dam, at the upper portion of the floodplain, and adjacent to WOC (Van Voris and Dahlman 1976, Dahlman et al. 1980). Lower concentrations of radionuclides in soil are found along the lateral perimeter of the floodplain. The highest concentrations of ${ }^{137} \mathrm{Cs}$ are found in the subsoil at a depth of $22-32 \mathrm{~cm}$.

Detailed biogeochemical studies of $\mathrm{U}, \mathrm{Th}, \mathrm{Pu}$, and other transuranic elements have been conducted on the WOC floodplain. The concentrations of $239,240 \mathrm{Pu}$ in floodplain soil, which range from -10 to $150 \mathrm{pCi} / \mathrm{g}$ dry wt over the 3-ha area of the floodplain, are highest in the $0-$ to $10-\mathrm{cm}$ zone of the soil profile (Dahlman et al. 1980) The plutonium in the floodplain soil is associated predominantly with clay particles $(<2 \mu \mathrm{m})$, and the particle size distribution of the soil is $>708$ silt-clay (Tamura 1976). Soil plutonium is most likely in the +IV valence state, predominantly monomeric, surface sorbed, and partly associated with humic material (Bondietti et al. 1976). Plutonium and natural thorium exhibit similar extractabilities from floodplain soil with mild reagent, while uranium is appreciably more extractable (Bondietti and Sweeton 1977). Dahlman et al. (1980) estimated that the total inventory of ${ }^{239,240} \mathrm{Pu}$ in the top $20 \mathrm{~cm}$ of soil for the entire 3 -ha area was $0.5 \mathrm{Ci}$. Radioecological studies carried out over the years at ORNL have provided considerable insights into the availability of radionuclides to both terrestrial plants and animals. Auerbach and Crossley (1958) measured ${ }^{90} \mathrm{Sr}$ and ${ }^{137} \mathrm{Cs}$ in native plant species on woL bed from 1956 to 19'j8. These radionuclides were taken up more efficiently by some species than by others, and the higher levels were generally found in leaves than in stems and flowers. The radionuclide inventory in vegetation did not change appreciably during the course of their study. 
Three species of forage crops planted on the lake bed (Auerbach 1959) also showed highly significant differences amorg crops in radionuclide uptake, with concentrations of ${ }^{90} \mathrm{Sr}$ and ${ }^{137} \mathrm{Cs}$ being higher in millet and Sudan grass than in fodder cane. Concentrations of ${ }^{90} \mathrm{Sr}$ in millet and Sudan grass were more than twice the ${ }^{90} \mathrm{Sr}$ concentration in soil on which the forage crops were grown. In subsequent studies (Auerbach 1961), significant reductions in ${ }^{90} \mathrm{Sr},{ }^{137} \mathrm{Cs}$, and ${ }^{106} \mathrm{Ru}$ uptake were shown in the field and greenhouse experiments as a result of superphosphate fertilizer treatments.

Analysis of trees from the east and west seepage areas showed high levels of gross beta activity (Auerbach 1957), which was attributed to high concentrations of ${ }^{106} \mathrm{Ru}$ reaching the trees through contaminated groundwater. Trees growing in known seepage areas had levels of ${ }^{106} \mathrm{Ru}$ well above those observed for nearby trees affected only by aerial contamination (Auerbach and 0lson 1963). More-recent sampling of tree leaves and groundwaters from the east and west seepage areas has shown the presence of ${ }^{99} \mathrm{Tc},{ }^{233} \mathrm{U}$, and ${ }^{60} \mathrm{Co}$ in groundwaters and tree leaves (01sen et al. 1983). Of these three radionuclides, only ${ }^{99} \mathrm{Tc}$ accumulated to an appreciable extent in forest vegetation. Bondietti and Garten (1986) showed that organic matter in the soil appears to be an important sink for ${ }^{99} \mathrm{Tc}$ in the terrestrial system, although its contribution to the total immobilized fraction remains unquantified.

Few data are available on the exact levels and extent of contamination in herbaceous vegetation and trees growing in the cobalt seep. Tritium and technetium are probably present based on the levels of groundwater contamination. Wood samples taken in 1985 from maple and sweetgum trees less than $100 \mathrm{~m}$ west of Trench 7 (at we11 WT7-3) were found to contain between 50 and $125 \mathrm{pCi} / \mathrm{g}$ dry wt (C. T. Garten, Oak Ridge National Laboratory, unpublished data). This contamination undoubtedly results from root uptake of contaminated groundwater that contained $2400 \mathrm{pCi} / \mathrm{L}$ of ${ }^{99} \mathrm{Tc}$ at well WT7-3.

Thirty years after initial contamination, vegetation:soil ratios for ${ }^{137} \mathrm{Cs}$ in plant species on the wOC floodplain ranged from 0.001 to 0.53 , demonstrating that the relative distribution of radiocesium between plants and soil has not changed from distributions reported for 
the wOL bed 15 years earlier (Dahlman and Van Voris 1976). The relative concentration ratio on a per-gram basis averaged 0.03 for vegetation:soil. Average radiocesium concentrations in herbaceous plants, tree leaves, tree wood, and leaf fall from the wOC floodplain in 1974 were less than those measured in native vegetation on the wOL bed more than a decade earlier.

DeSelm and Shanks (1963) estimated that -78 and 28 of the soil strontium was removed by lake bed willows and herbaceous communities, respectively. For ${ }^{137} \mathrm{Cs}$ and ${ }^{60} \mathrm{Co}$, lake bed vegetation was estimated to have removed less than 0.38 of the soil radionuclides. Much of this removal was recycled back into the topsoil as litter.

Studies on the uptake and effects of radionuclides to terrestrial animals and plants at ORNL have focused on invertebrates (especially insects) and small mammals. Studies cf insect food chains on the lake bed were initiated in the summer of 1956 (Auerbach 1958) and were continued through about 1964 (Crossley 1969). Concentrations of ${ }^{137}$ Cs in insects were almost as high as in the plant tissues upon which insects were feeding; however, ${ }^{90} \mathrm{Sr}$ concentrations in insects were nearly an order of magnitude lower than those found in plants (Auerbach 1959, Crossley and Howden 1961). Concentration data for lake bed soil, plants, and insects showed that reduction in the food-chain transfer of ${ }^{90} \mathrm{Sr}$ occurred principally at the point of plant-to-insect transfer, while ${ }^{137} \mathrm{Cs}$ movement up the food chain was reduced at the point of soil-to-plant transfer (Crossley and Howden 1961).

Results of uptake-elimination studies indicated that the radiocesium concentration in grasshoppers feeding on contaminated vegetation on the lake bed was expected to rapidly come to equilibrium with concentrations in the vegetation (Crossley and Pryor 1960, Auerbach 1959). Based on statistical relationships between the biological half-life of ${ }^{137} \mathrm{Cs}$ and insect body weight, it was estimated that insect consumption was $5 \%$ to 68 of the existing plant biomass on the lake bed (Crossley 1963, Auerbach 1961). Crossley (1963) concluded that insects had little effect on the removal and redistribution of radionuclides on the lake bed. In the extreme case, Crossley calculated that if all 
insects had left the lake bed at one time, the loss of radionuclides would be $-3 \mathrm{Ci}$ each of ${ }^{90} \mathrm{Sr}$ and ${ }^{137} \mathrm{Cs}$.

Insect communities on the upper portion of wOL bed were resampled in 1964 near a known source of ${ }^{106} \mathrm{Ru}$ contamination (Crossley 1969). As in previous studies, ${ }^{137} \mathrm{Cs}$ exhibited little plant uptake and a more efficient food-chain transfer from plant to insect. Both ${ }^{60} \mathrm{Co}$ and ${ }^{106} \mathrm{Ru}$ exhibited higher plant uptake and more-efficient transfer from plant to insect than did ${ }^{137} \mathrm{Cs}$. Due to the short radioactive half-life of ${ }^{106} \mathrm{Ru}$ (369 d), present-day concentrations of this radionuclide in the upper lake bed soil are estimated at femtocurie-per-kilogram levels. Research on small mammals inhabiting the wOL bed was initiated in December 1957 (Auerbach 1958). The purposes of this research were to study the long-term effects of chronic, low-level radiation $(-20 \mathrm{mR} / \mathrm{h})$ on small-mammal populations and the uptake of fission products through terrestrial food chains. House mice (Mus musculus) were the predominant small-mammal species inhabiting the lake bed in late 1956 and early 1957. This species was replaced by cotton rats (Sigmodon hispidus) and rice rats (Oryzomys plaustris) during late 1957 and early 1958 (Auerbach 1958).

Estimated dose rates from internal and external radioactivity for cotton rats inhabiting the lower lake bed in 1960 were initially approximated at $3 \mathrm{rems} /$ week (Kaye and Dunaway 1963). Most of the dose $(\sim 708)$ from internally deposited radionuclides arose from the accumulation of ${ }^{90} \mathrm{Sr}$. Estimated lifetime doses for small mammals on the lake bed from the external radiation field were -60 rems (Kaye and Dunaway 1963). Further studies with rats bearing subcutaneous glassrod dosimeters showed that the average absorbed daily dose rate was between 1 and 3 rads (Auerbach 1963). Despite the increased levels of internal and external exposure, Dunaway and Kaye (1963) concluded from their studies of small-mammal populations that effects of ionizing radiation on mammals from the lake bed were not discernible. Although the average litter size of cotton rats on the lake bed was smaller than in uncontaminated areas, the survival of the rats on the lake bed was better than that in reference areas. Also, there was less incidence of lesions and other pathological conditions in white-footed mice from the 
lake bed in 1960 than in mice from uncontaminated areas (Dunaway and Kaye 1963). Possible effects of lake bed radiation on cotton rat weights, breeding condition (Dunaway and Kaye 1964), and hematology (Auerbach 1962, 1963) were not unequivocally demonstrated. In similar studies of cotton rats, white-footed mice, and rice rats (Childs and Cosgrove 1966) from wOL bed, the levels of radiation exposure were found to be too low to result in somatic effects on small mammals. Pathologic and parasitologic findings appeared to be coincidental to radionuclide contamination of the environment, but no causal relation was postulated.

Concentrations of ${ }^{90} \mathrm{Sr}$ in small mammals inhabiting the lake bed were 35 times higher than those found in birds (Auerbach 1960). Similarly, based on concentration data and measurements of population densities, Kaye and Dunaway (1962) estimated that body burdens of ${ }^{90} \mathrm{Sr}$ in small mammals were considerably higher than body burdens of ${ }^{90} \mathrm{Sr}$ in birds on the lake bed.

Studies on the uptake of fission product radionuclides by birds frequenting the lake bed during 1958 and 1959 (Willard 1960) showed that birds feeding close to the ground (sparrows, thrushes, and chats) exhibited the highest levels of gross beta activity in body tissues (exclusive of feathers and gastrointestinal tract). The concentration of ${ }^{90} \mathrm{Sr}$ in bird bones was about six times greater than that of ${ }^{137} \mathrm{Cs}$ in bird muscle. Higher concentrations of ${ }^{90} \mathrm{Sr}$ and ${ }^{137} \mathrm{Cs}$ in birds during the winter were attributed to the direct ingestion of contaminated soil as a result of birds probing the soft soil for plant seeds. Willard (1960) estimated the amount of ${ }^{90} \mathrm{Sr}$ and ${ }^{137} \mathrm{Cs}$ in birds occupying the lake bed to be 7 and $19 \mathrm{nCi} /$ acre, respectively; thus, the total amount of radioactivity that was at risk of removal through migration was considered negligible ( 0.2 to $0.6 \mu \mathrm{Ci}$ for the entire lake bed). However, the maximum observed levels of ${ }^{90} \mathrm{Sr}$ in bird bones exceeded the concentration that is permissible in humans (Willard 1960).

\subsubsection{Surveys of Terrestrial Biota}

Extensive information exists on the terrestrial flora and fauna of ORR, including WOC watershed (e.g., see Krumholz 1954a, Johnson 1964, 01son et al. 1966, Grigal and Goldstein 1971, Mann and Bierner 1975, 
Anderson et al. 1977, Johnson et al. 1979, Bradburn and Rosenbalm 1984). The vegetation of undeveloped portions of the ORNL site is similar to the vegetation of ORR as a whole (Boyle et al. 1982), which is described by Kitchings and Mann (1976), Dahlman et al. (1977), and DOE (1980). The occurrence of threatened and endangered species on ORR and the distribution of plant communities (and the fauna associated with them) have been described by Kitchings and Mann (1976). Recent information on threatened and endangered species on ORR is provided in Boyle et al. (1982), Kitchings and Story (1984), and Parr (1984a, 1984b).

The Oak Ridge Wildlife Management Area was established on ORR in November 1984 under a cooperative agreement between DOE and the Tennessee Wildlife Resources Agency. A series of organized public deer hunts was established for the first time in 1985 to reduce the number of deer-vehicle collisions and to provide recreational hunting. In late 1985, several wild turkeys were released on ORR as part of an effort to establish turkey populations in several areas of the state. 


\section{BIOLOGICAL MONITORING TASKS}

BMAP for WOC watershed and the Clinch River consists of seven major tasks: (1) toxicity monitoring; (2) bioaccumulation of nonradiological contaminants in aquatic biota; (3) biological indicator studies;

(4) instream monitoring of benthic invertebrate and fish communities;

(5) assessment of contaminants in the terrestrial environment;

(6) radioecology of WOL and WOC; and (7) contaminant transport, distribution, and fate in the WOC embayment-Clinch River-Watts Bar Reservoir system. The comprehensive nature of the proposed BMAP reflects the high level of environmental complexity and uncertainty associated with contaminant concentrations and sources, including, for example, the complex nature of the effluents discharged to WOC, the expected temporal variability in the effluent composition, and the spatial variability in contaminant distribution (Sect. 1.3).

The basic structure of BMAP represents a combination of ecological research, established monitoring protocols, and innovative state-ofthe-art approaches to biomonitoring. Although details are provided of the specific procedures to be utilized in the initial stages of BMAP, experimental designs associated with some studies, especially those that will be implemented after the first year, are described in less detail. The overall strategy is to use results obtained in the initial characterization studies to define the scope of future monitoring efforts. Such efforts may require more-intensive sampling than initially proposed in some areas (e.g., additional toxicity testing if initial results indicate poor survival or growth) and a reduced sampling intensity in others. By using the results of previous monitoring efforts to define the needs and short-term goals of future studies, an effective, integrated monitoring program can be developed to ensure protection of the ecological integrity of the WOC watershed.

\subsection{TOXICITY MONITORING (TASK 1)}

Toxicity tests are preferred alternatives to chemical analyses when effluents or sediments contain ccmplex mixtures of substances (EPA 1985b). However, toxicity testing as a means to assess water or 
sediment quality is still a relatively new approach. In this task, we develop a toxicity monitoring plan with three goals: (1) to monitor the toxicity of water and sediments in WOC and its tributaries and in reference streams; (2) to evaluate the toxicity test systems used at these sites, with respect to their ability to detect toxicity at levels that are found to damage stream ecosystems; and (3) to test, by using manipulative field experiments and instream monitoring, relaiionships between ambient toxicity and key processes regulating energy flow in streams within the WOC watershed. In general, the condition of streams at the start of the program will be compared with their condition following implementation of ORNL WPCP to quantitatively assess changes in toxicity that can be attributed to improvements in water quality of streams in WOC watershed.

The toxicity monitoring task consists of three subtasks: (1a) evaluations of point-and area-source toxicity, (1b) ambient toxicity testing of stream water with laboratory bioassays, and (1c) instream monitoring of periphyton and microbial communities. These three subtasks are designed to assess the quality of water and sediments in streams of the WOC drainage system over different spatial and temporal scales. Integration of the data obtained from these subtasks with data obtained from physicochemical analyses of water and sediments from the same sites will provide a more complete picture of the environmental impacts of the ORNL facility on water quality and biotic processes in the WOC watershed.

\subsubsection{Subtask 1a: Evaluation of Point-and Area-Source Toxicity}

The purpose of this subtask is twofold: (1) to identify sources of toxicity in streams on ORR not specifically designated as testing sites in the Toxicity Control and Monitoring Program (TCMP), as outlined in Part V of the NPDES permit (EPA 1986), and (2) to provide diagnostic, quantitative data that plant operators can use to develop more-effective procedures for reducing or eliminating specific sources of toxicity in the streams. The evaluations performed in this subtask will supplement testing of TCMP outfall sites de: cribed in the NPDES permit (Part V). 
Point-source inputs of effluent include specific process waste streams directed to the WOC system (cooling tower blowdown discharges, chlorine inputs due to tap water discharges, etc.). Area-source inputs, in contrast, are those that enter the stream system more diffusely as surface runoff or as subsurface horizontal transport in response to precipitation or to groundwater movement. An example of an area-source input would be surface or subsurface runoff from an inadequately contained hazardous-waste burial ground. Both point-and area-source contributions to instream toxicity will be evaluated in this subtask.

Toxicity of point-and area-source inputs to the WOC system will be determined using two newly developed "short-chronic" toxicity tests: the 7-d fathead minnow (Pimephales promelas) larval growth test (Norberg and Mount 1985) and the Ceriodaphnia 7-d 1ife-cycle test (Mount and Norberg 1984). These tests will follow recommended practices for effluent toxicity testing (Peltier and Weber 1985).

The appropriate dilution series to be used in toxicity tests of stream water, runoff, and effluents will be determined from initial screening tests. If water from instream sampling sites is of low toxicity, subsequent tests will use only full-strength stream water. In such cases toxicity will be expressed as percent reduction in survival and growth (for fathead minnows) or in survival and fecundity (for Ceriodaphnia) relative to controls, and one-way analysis of variance (ANOVA) will be used to test for the presence of site-to-site differences $(p<0.05)$ in toxicity. If significant between-site effects are found, problematic sites will be identified relative to controls by using a procedure such as Dunnett's test (Steel and Torrie 1960). If initial screening tests of a particular site indicate the presence of substantial toxicity (i.e., 50 reduction in survival or fecundity compared with controls), subsequent tests based on a dilution series will be used to permit determination of the lowest-observed-effect concentration (LOEC), no-observed-effect concentration (NOEC), and/or the median lethal and median effective concentrations $\left(\mathrm{LC}_{50}\right.$ and $\mathrm{EC}_{50}$ values, respectively). The latter calculations will be based on data for survival, growth, and (for Ceriodaphnia) fecundity in test samples, control water, and/or water samples from appropriate reference sites. 
Dechlorinated tap water will be used as dilution water and as control water in toxicity tests with fathead minnows, and aged, reconstituted, hard water will be used as dilution and as control water in tests with Ceriodaphnia. As in studies involved with point-source toxicity testing at the Oak Ridge Y-12 Plant (Loar et al. 1989), natural variability of water in the reference streams precludes this water from being used as controls or for dilution water when results must be compared over time.

Testing schedules used to identify point-source contributions to instream toxicity will be determined on a case-by-case basis; factors governing selection of the most appropriate sampling schedule for a given site include the degree of toxicity, the discharge rate of input relative to that of the receiving body of water, and the inherent variability of the input source. Because area-source inputs can occur as a result of storm events or groundwater movements, such inputs may not be readily sampled on a fixed schedule. Samples will be obtained during storm events by using runoff traps positioned to intercept the laterally moving water before it enters a stream. Runoff samples collected from reference sites (sites geomorphologically and floristically similar to those of the suspected area sources) will be used as reference water in these studies.

A 24-h static test using fathead minnow larvae and Ceriodaphnia will be conducted monthly to reference fitness of the two test species; the toxicant used in these tests will be cadmium chloride. Results of a toxicity test will be considered to be invalid and the test will be repeated if the response of the test organisms to cadmium chloride falls outside of the acceptable range.

\subsubsection{Subtask 1b: Ambient Toxicity Testing}

The purpose of this subtask is to provide information on the quality of water and sediment in WOC and tributaries over relatively large spatial and temporal scales. This subtask will be accomplished by testing the toxicity of water (as described in Sect. 3.1.1) and sediments collected from upstream and downstream sites of seiected streams (e.g., MB, WOC, First Creek, Fifth Creek, NWT). Toxicity of 
water from the sites will be tested monthly for 1 year and quarterly thereafter for the duration of the permit.

Sediment will be tested for toxicity by using Elodea canadensis, a locally common, rooted vascular macrophyte. For this test, 5-7 subsamples of sediment from each site will be composited and sieved to pass a $1-\mathrm{mm}$ mesh. Five subsamples (each $-30-\mathrm{g}$ wet $w t$ ) of each sediment sample will be used for each test. A $6-\mathrm{cm}$ sprig of Elodea will be planted $3 \mathrm{~cm}$ deep into each replicate beaker. The beaker-sedimentElodea test systems will then be incubated in dechlorinated tap water at $25^{\circ} \mathrm{C}$ under fluorescent lights for 4 weeks. At the end of the test period, root (i.e., below-sediment) and shoot (i.e., above-sediment) biomass (measured as ash-free dry weight) of the Elodea will be determined gravimetrically. Data collected from this portion of the subtask will be analyzed by ANOVA to detect whether significant differences exist between sites; Dunnett's test will be used to identify sites containing sediment that significantly affects $(p<0.05)$ root or shoot growth of Elodea. Portions of the tested sediment will be analyzed for organic content (by combustion at $525^{\circ} \mathrm{C}$ ); the remaining tested sediment will be frozen and archived. Because sediment toxicity is more likely to vary spatially than temporally, only one test will be performed; however, in that test, the toxicity of sediments collected from 20-25 sites will be evaluated.

Toxicity tests of stream water and sediment will provide data over monthly, seasonal, and annual time scales. This subtask will allow unequivocal identification of sources of toxicity and will provide baseline information on site-to-site differences in water quality of wOC and its tributaries at various times. The data obtained in this subtask will be analyzed by statistically partitioning site- and time-dependent variance components as described by Threlkeld (1983). Finally, because toxicity of the water at each site will be evaluated by using side-by-side tests of two types of organisms (a microcrustacean, Ceriodaphnia dubia/affinis, and a fish, Pimephales promelas) on each sampling date, the data will permit the most critical evaluation to date of the utility of such tests with respect to their ability to characterize ambient toxicity of surface waters that contain complex 
mixtures of potentially hazardous effluents. This information will facilitate development of the water pollution control programs presently directed by the EPA.

Water and sediment to be tested for toxicity will be transported from sites on WOC (and its tributaries) to the Aquatic Ecology Laboratory at ORNL, using existing chain-of-custody procedures. Ambient toxicity tests described in Subtasks $1 \mathrm{a}$ and $1 \mathrm{~b}$ will be determined with the use of daily grab samples. Grab sampling will also be used to collect water from the runoff traps positioned to collect water from variable-source inputs as described in Subtask $1 b$.

\subsubsection{Subtask 1c: Instream Monitoring of Periphyton and Microbial Communities}

Consumption of plants by animals is the foundation of trophic structure in all ecosystems. The production of autochthonous organic matter in streams is regulated largely by benthic algae, and its processing is carried out by benthic macroinvertebrates and microbial decomposers. Studies of benthic algae and microbial decomposers can provide information regarding the flux of energy and nutrients through all higher trophic levels (e.g., invertebrates and fish). Finally, because periphyton have high turnover rates, they are included in this subtask of BMAP to assess ecological responses to short-term changes (e.g., infrequent pulses of toxicants).

Benthic algae in many streams are the principal food source for aquatic herbivores (see review by Gregory 1983). Alterations in water quality that reduce the productivity or standing crop of stream periphyton (the community of organisms colonizing substrates within the stream) can therefore affect the entire trophic structure of a stream community. Two types of studies will be used to evaluate the relationships between water quality and effects on periphyton communities in WOC and its tributaries. In the first study, periphyton developing on uniform substrates incubated within the streams will be analyzed each month for 1 year to determine (1) rates of biomass accumulation, (2) species composition, (3) productivity, and (4) food quality (i.e., as indicated by adenosine triphosphate content and 
carbon:nitrogen ratios) for herivivores. In the second study, additional replicate substrates will be incubated at reference sites for 4- to 6 -week periods to permit periphyton communities to develop. The substrates and their attendant periphyton communities will then be transplanted into sites in wOC for 24 - or 48 -h periods. The periphyton communities on these substrates will be collected and analyzed for changes in productivity and for their ability to respond photosynthetically to nutrient enrichment when transplanted back to the reference sites. Loss of ability to increase photosynthetic rates when a nutrient previously limiting productivity is made available in nonlimiting quantities will, in this case, serve as an index of periphyton community damage due to toxicity.

Allochthonous organic matter (that synthesized outside of the stream per se; e.g., leaf litter) also sustains the trophodynamic structure of stream communities and may become more important than autochthonous organic matter (synthesized within the stream) in small shaded streams (Bott 1983). The decomposition of allochthonous organic matter by bacteria and fungi alters the nutritional quality and rate of availability of food to stream animals in higher trophic levels. As is true for periphyton, changes in water quality can affect the activities of bacteria and fungi. To evaluate the effects of water quality on microbial activity, we will measure, at quarterly intervals for the first year, rates of microbial activity on natural leaf substrates and rates of microbial growth (as thymidine uptake) on artificial substrates incubated at various sites in streams within the wOC watershed. Transplant experiments similar to those described for the periphyton studies will be initiated if the results of the microbial studies during the first year indicate that instream toxicity alters rates of microbial activity.

To evaluate contributions of allochthonous and autochthonous organic inputs to the overall flow of energy at different sites in the streams, we will compare rates of primary production ( $P$ ) to rates of respiration ( $R$ ) of periphyton and sediment microbiota. The P:R measurements provide basic information on the functioning and character of stream reaches. When evaluated in the context of information 
obtained for specific processes (e.g., chlorophyll-specific rates of carbon fixation, microbial activity on natural substrates), the $P: R$ ratio for impacted and undisturbed stream reaches will provide an additional basis for assessing both the impacts of effluent discharges and the effects of remedial actions. The $P: R$ measurements will be made by using light and dark chambers positioned in situ over natural substrates (cf. Bott 1983). The P:R values for various streams within the WOC watershed will be determined at key periods during the growing season to characterize various reaches with respect to their patterns of energy utilization (autotrophic vs heterotrophic).

\subsection{BIOACCUMULATION MONITORING OF NONRADIOLOGICAL CONTAMINANTS IN AQUATIC BIOTA (TASK 2)}

The bioaccumulation monitoring program for nonradiological contaminants will focus on determining whether potentially hazardous levels of contaminants presently accumulate in aquatic biota downstream from ORNL facilities or may accumulate in the future. If present or future contamination is determined, the extent of the problem, its sources, and the effectiveness of remedial actions must be addressed. Specific objectives of this task are

1. to determine what materials present in WOC, MB, WOL, and WOL embayment accumulate to unacceptable levels in aquatic biota and to determine the effects of remedial actions on levels of these contaminants in biota;

2. to determine the importance of present vs past discharges in contributing to the observed levels of accumulation in aquatic biota and to identify specific sources of contamination;

3. to provide information with which to calibrate water quality data gathered under the NPDES monitoring programs at ORNL and at the Oak Ridge Y-12 Plant against contaminant levels in fish, so that water quality data can be used to infer that contaminants are not accumulating to unacceptable levels in aquatic biota;

4. to determine the source and scope of $\mathrm{PCB}$ contamination of channel catfish in WOC embayment and the Clinch River; and 
5. to utilize results of studies carried out under the Oak Ridge Y-12 Plant BMAP for East Fork Poplar Creek (Loar et al. 1989) to understand and model the dynamics of bioaccumulation. After developing, calibrating, and testing the model for parameters specific to the WOC system, the model will be used to predict contaminant accumulation and to forecast future levels of contamination of biota in the wOC watershed under different vemedial action alternatives.

The biological monitoring task is divided into five subtasks, each of which addresses one of the task objectives.

\subsubsection{Subtask 2a: Identification of Contaminants that Accumulate in Aquatic Blota}

Data from the 1984 Oak Ridge Task Force survey (TVA 1985) indicate that only mercury and PCBs occur at levels greater than background in fish in WOL, and, in each case, levels are well below statutory limits. However, no measurements have been made on fish upstream of the lake, where lower levels of suspended particulate material and less dilution could enhance contaminant accumulation in biota. Because no data exist for these sites, this task will initially focus on a broad-spectrum analysis of inorganic and organic contaminants at sites within the WOC watershed.

WOC and MB both contain moderate populations of bluegill (Lepomis macrochirus) and redbreast sunfish (Lepomis auritus) concentrated in the pools and tailwaters of monitoring weirs at several sites within the watershed. The weirs act to block upstream passage of fish and thus help ensure that fish collected at a site reflect the exposure history characteristic of that site. Advantages of using one or both of these species in monitoring for bioaccumulation are (1) their relatively short life span, which yields a more consistent exposure history within the group of fish sampled; (2) their adaptability to the laboratory environment; (3) the existence of a historical record of contamination in bluegill in WOL; and (4) the large size (relative to species more typical of wOC, such as blacknose dace) of individual fish. Data 
obtained for these species will also be directly comparable with data collected in the Oak Ridge Y-12 Plant BMAP for East Fork Poplar Creek (Loar et al. 1989), where bluegill and redbreast sunfish are the primary species monitored in East Fork Poplar Creek.

Carp (Cyprinus carpio) in East Fork Poplar Creek contained significantly higher levels of PCBs in 1984 (TVA 1985) and 1985

(G. R. Southworth, Oak Ridge National Laboratory, unpublished data) than did sunfish species, although levels of metals differed little between the two species. Carp are found in wOL and wOC embayment, but not in that portion of the watershed above WOL. If channel catfish cannot be collected in adequate numbers in WOL, carp will be used as a monitor for organic contaminants in long-lived, lipid-rich fish in wOL.

Since fish can readily metabolize many organic contaminants, preventing their accumulation in tissues, a bivalve species, either Corbicula fluminea or a native, stream-dwelling species, will be introduced in enclosures to monitor for substances such as polycyclic aromatic hydrocarbons (PAHs) and phthalate esters, which are not as readily metabolized by mollusks.

Fish will be collected annually at four potentially impacted sites in the WOC drainage above WOL: the weirs on MB and WOC immediately above the confluence of the two streams (NPDES sites X13 and X14, respectively), the weir on WOC just above SWSA 4 and immediately below Melton Valley Drive, and the weir on NWT just above the confluence with First Creek (Fig. 2). Fish will also be collected from wOL and WOC embayment. Two control sites will be used; one, Target Range Pond on First Creek, is in the WOC drainage, and the other, Brushy Fork, is in the Poplar Creek drainage and currently serves as a control site for the Oak Ridge Y-12 Plant for East Fork Poplar Creek (Loar et al. 1989).

Fish tissues will be analyzed for the suite of metals monitored monthly at the three surface water monitoring stations (X13, X14, X15; see Fig. 2) included in the NPDES permit for ORNL (EPA 1986). These metals are $\mathrm{Al}, \mathrm{As}, \mathrm{Cd}, \mathrm{Cr}, \mathrm{Cu}, \mathrm{Pu}, \mathrm{Fe}, \mathrm{Mn}, \mathrm{Hg}, \mathrm{Ni}$, and $\mathrm{Zn}$. PCBs will be specifically analyzed, and a screening of fish extracts by gas chromatographic mass spectrometry (GC/MS) will be conducted to look for other hydrophobic organic contaminants. Corbicula will be analyzed 
specifically for PAHs (by using high-performance liquid chromatography/ fluorimetric detection) and screened for other organics by using GC/MS.

The data will be evaluated through the use of risk-analysis screening procedures (Hoffman et al. 1984), statutory limitations (for mercury and $\mathrm{PCBs}$ ), and comparison with background levels to identify those materials that accumulate in biota from the WOC watershed and to determine which contaminants, if any, warrant more-detailed investigation.

\subsubsection{Subtask 2b: Identification of Contaminant Sources}

Subtask 2a will identify substances that warrant further investigation. The most probable materials to be selected for such studies are mercury and PCBs, based on their history of contamination in WOC and their high bioaccumulation potential. In the NPDES permit, mercury and PCBs (J. N. Dumont, Oak Ridge National Laboratory, personal communication to J. T. Kitchings, Oak Ridge National Laboratory, 1986) have separate monitoring programs aimed at identifying specific sources of active contamination (EPA 1986). If the results from Subtask 2a indicate a need to identify sources of mercury or PCB contamination in the WOC watershed, results of the specific monitoring program (mercury or PCB) will be combined with the results of Subtask $2 a$ to identify the nature and source of the problem (e.g., point source, residual contamination in sediment, combined sources). The study design of Subtask $2 \mathrm{~b}$ will be based on the findings of these previous studies. For example, if a point source is suspected but not isolated by the PCB monitoring plan, an active source of contamination will be located by placing caged minnows in the stream for $30-d$ periods at different sites near the suspected source area. Small fish accumulate contaminants more rapidly than large fish and should attain detectable levels in a $30-d$ exposure period. Such activities will be closely coordinated with ORNL Department of Environmental Management (DEM) personnel involved in the specific monitoring plans. If a point source is located and remedial actions are undertaken, a monitoring program will be established to collect fish every 6 months at downstream monitoring sites (those used in Subtask $2 a$ ) to document the effectiveness of remedial measures. 
If no specific source is located or suspected, Subtask $2 b$ will document that the suspected general source (most probably residual contamination in sediments) can, in fact, account for the observed contamination of biota. Such studies will involve exposing fish to contaminated sediment in laboratory aquaria receiving inputs of uncontaminated water. The specific experimental design will be determined by the suspected nature of the contaminant source distribution. If a general source (runoff, sediments, groundwater) is determined to be the problem, then the sampling outlined in Subtask 2a should be adequate to document changes over time, unless specific remedial actions are implemented.

\subsubsection{Subtask 2c: Integration of Water Quality and Bloaccumulation Data}

A comprehensive data set characterizing concentrations of trace metals and PCBs in water from MB, WOC, and WOL (sites X13, X14, and X15, respectively) and East Fork Poplar Creek (site 303) will be generated as a result of monthly monitoring conducted under the NPDES permits for ORNL and the Oak Ridge Y-12 Plant. The sites monitored in these programs and control sites should provide a range of levels of contamination with various trace metals. In Subtask $2 c$, the observed levels of trace metals and PCBs in fish at these four NPDES sites will be compared with measured concentrations of these contaminants in water at those sites. The data will be analyzed to evaluate whether the aqueous-phase measurements for specific contaminants can be used to predict contaminant levels in fish and to establish whether accumulation to potentially hazardous levels occurs. These data will also provide an opportunity to evaluate how interactions among water quality parameters might affect bioaccumulation, including variables such as nutrient status and turbidity, as well as metal and PCB concentrations. Potentially, these results could be used to improve the design of monitoring programs, such as establishing appropriate detection limits and reducing emphasis on substances with little or no potential to accumulate in aquatic biota. 


\subsubsection{Subtask 2d: Evaluation of PCB Contamination}

Channel catfish collected $300 \mathrm{~m}$ upstream from the mouth of WOC embayment in 1984 were contaminated with PCBs in excess of the FDA action limit. Because this site is near waters open to public fishing (i.e., the Clinch River) and because the channel catfish is utilized as a food and game fish, there is cause for concern that catfish from the Clinch River may be contaminated. The initial effort of Subtask $2 \mathrm{~d}$ will be to delineate the geographical scope of $P C B$-contaminated channel catfish in the vicinity of WOC. Channel catfish will be collected by trotline from eight sites in the vicinity of WOC embayment:

1. WOL,

2. immediately below the spillway of White Oak Dam (WOL embayment),

3. WOL embayment $300 \mathrm{~m}$ upstream from mouth,

4. Clinch River $300 \mathrm{~m}$ upstream from mouth of wOC,

5. Clinch River $1.3 \mathrm{~km}$ upstream from mouth of WOC,

6. Clinch River $300 \mathrm{~m}$ downstream from mouth of WOC,

7. Clinch River $1.3 \mathrm{~km}$ downstream from mouth of WOC, and

8. Clinch River $3.3 \mathrm{~km}$ downstream from mouth of wOC.

This initial sampling should provide an estimate of the geographic scale of PCB contamination in channel catfish. Results of the initial study will be used to design a second survey to determine more precisely the scale of contamination, if necessary. Should results of the second survey indicate a problem of $\mathrm{PCB}$ contamination in Clinch River catfish due to releases from the WOC basin, a survey of sediments in the vicinity of contaminated fish will be conducted to locate the source of PCBs. Laboratory uptake studies using contaminated sediments from the sampling sites will also be performed (as in Subtask 2b) to verify that the sediments are indeed the source of the PCBs observed in fish.

\subsubsection{Subtask 2e: Bioaccumulation Modeling}

The Oak Ridge Y-12 Plant BMAP for East Fork Poplar Creek (Loar et a1. 1989) contains subtasks devoted to research into the dynamics of 
accumulation and the incorporation of those research results into models for predicting the fate of such contaminants in East Fork Poplar Creek (Loar et al. 1989). The data gathered in Subtasks $2 a-2 c$ of the ORNL Bioaccumulation Monitoring Task (Sects. 3.2.1-3.2.3) should be applicable to the models used in East Fork Poplar Creek. These data and those obtained from Task 7 (Sect. 3.7) will be used to calibrate the bioaccumulation models to the WOC watershed. Model predictions will be tested against field observations to ensure the validity of the model for the WOC system. Once such a calibrated model is available to describe contaminant levels in site-specific portions of the WOC watershed, simulations will be made for various remedial action scenarios. Estimates will be made for each scenario of the time course of the contaminant levels in different organisms. This calibrated model will be used to guide continuing remedial actions and provide a basis for cost-benefit analyses and decisions concerning future actions.

\subsection{BIOLOGICAL INDICATORS OF CONTAMINANT-RELATED STRESS (TASK 3)}

\subsubsection{Introduction}

Task 3 will involve the development and application of various biological indicators to evaluate the responses of fish populations in WOC watershed to point and area sources of contamination. Within the context of BMAP, biological indicators are defined as selected components or variables of organisms, populations, or communities that respond in biologically meaningful ways to changes in the environment (Tables 5 and 6). Bioindicators will be used in this task to address three major objectives: (1) identification and characterization of impacts on aquatic biota, (2) identification of contaminant sources that adversely affect stream biota, and (3) collection of baseline data that can be used to evaluate the effectiveness of remedial actions. The application of selected biological indicators, in conjunction with the toxicity monitoring and instream monitoring tasks (Sects. 3.1 and 3.4, respectively), can be used to address these three objectives in a timely and cost-effective manner. 


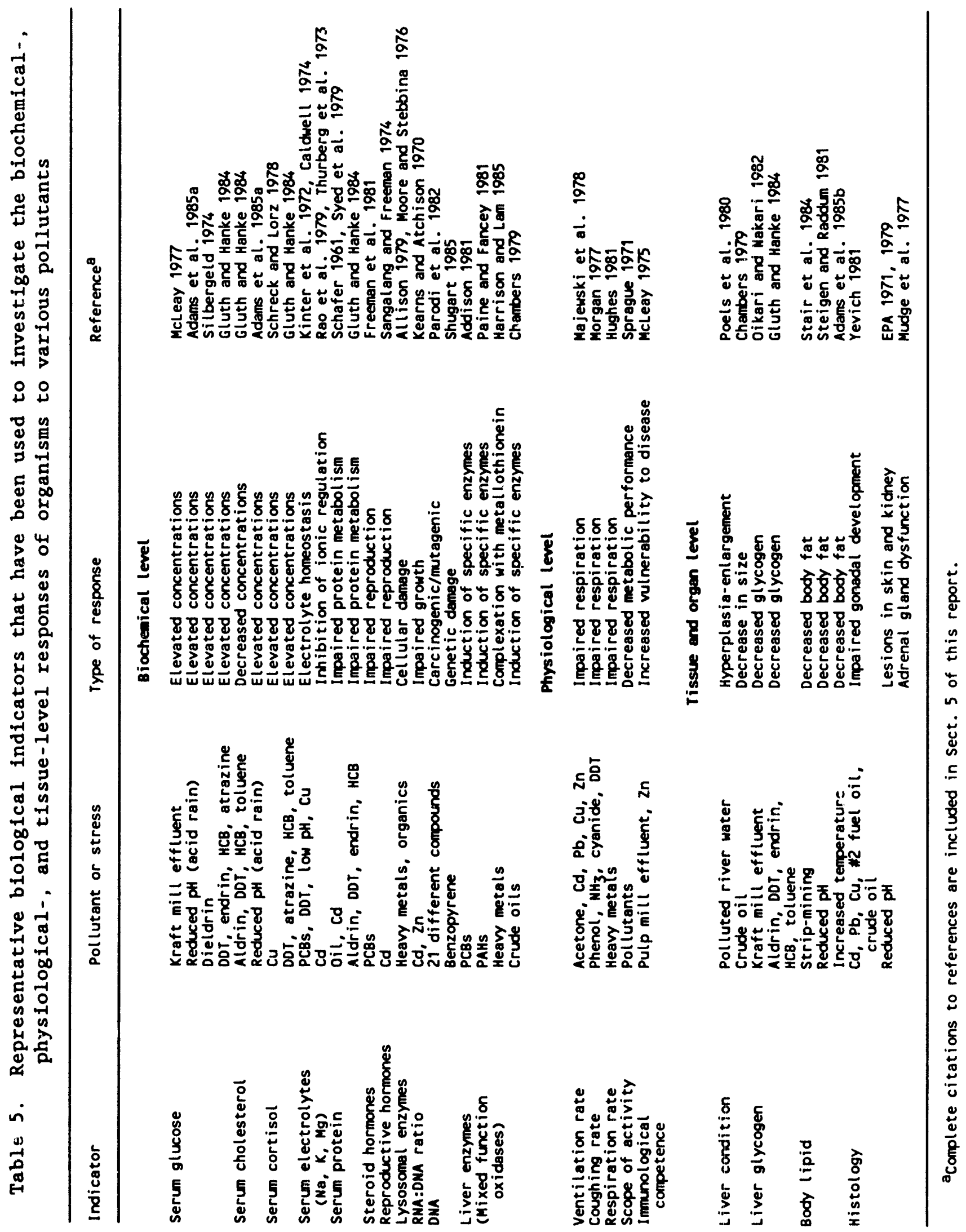




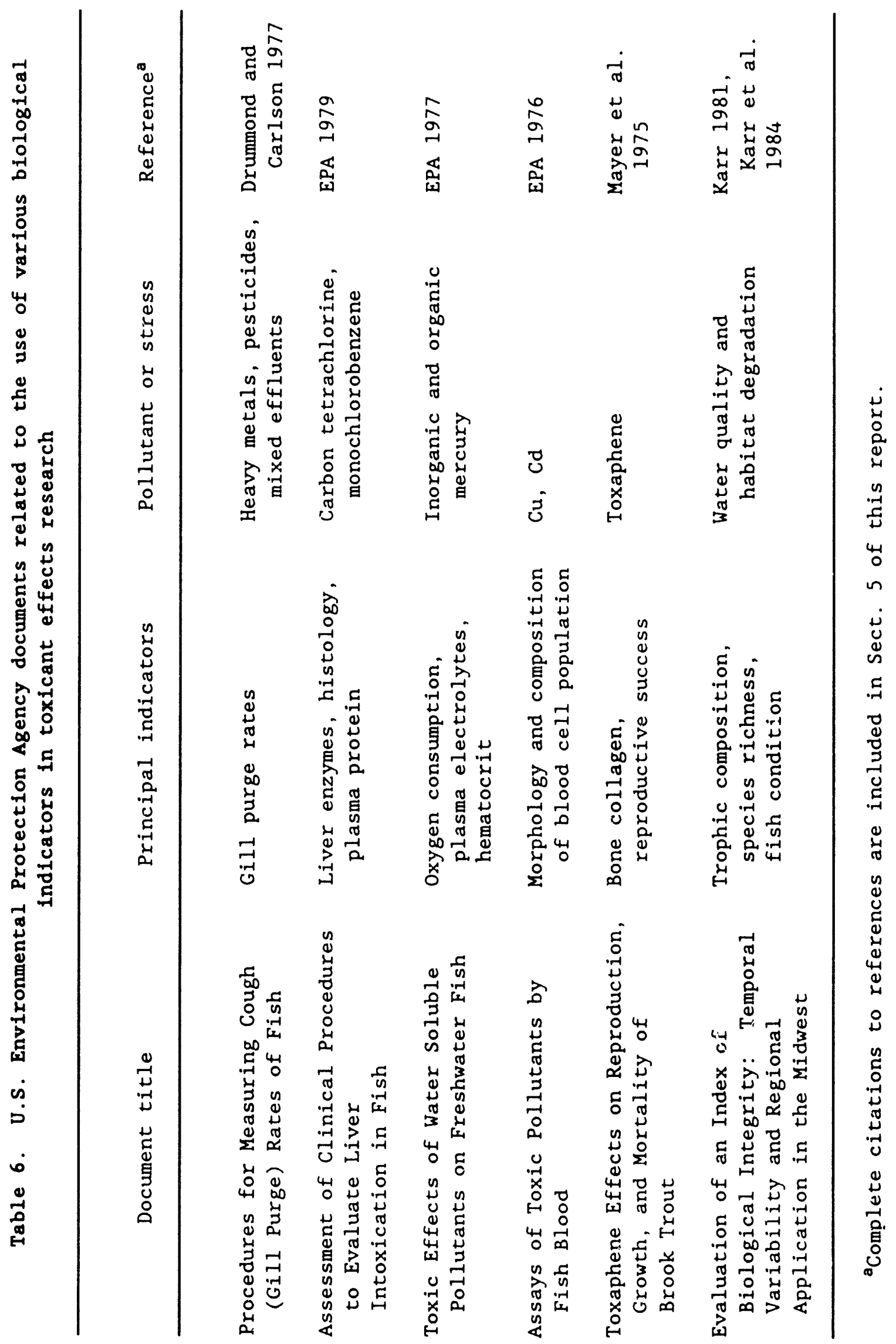


In biomonitoring programs designed to evaluate compliance with established water quality standards and to assess potential environmental effects, short-term laboratory toxicity tests (e.g., 24-h $\mathrm{LC}_{50}$ tests) are commonly used to determine the time required to elicit various levels of mortality in standard test organisms. This approach is generally acceptable for screening toxicant effects on a short-term basis (i.e., hours or days), but in most cases these criteria may be less appropriate for predicting or evaluating the longer-term, chronic effects of pollutants on biological populations and communities (i.e., growth, reproductive potential, trophic level status, abundance, diversity) (NRC 1981). Capabilities are needed, therefore, to identify and quantify responses of aquatic organisms and biological communities to sublethal chronic exposures before adverse, irreversible, or obviously undesirable effects on populations are realized (Adams and McLean 1985). In this regard, biological indicators not only can serve as early warning signals of impending ecosystem change, thus allowing time for remedial actions to be initiated, but can also provide early detection of the effectiveness of these remedial actions.

\subsection{1 Advantages of Biological Indicators}

The principal advantages of biological indicators over other methods for quantifying ecological responses to stress are (1) they can provide early warning signals of potential ecological effects because of cheir sensitivity to environmental change; (2) they can be used to identify causal mechanisms underlying observed effects at higher levels of biological organization, such as changes in population growth, reproductive success, and age structure; and (3) they are relatively easy to measure and cost-effective for long-term monitoring. These advantages are discussed in detail in Sects. 3.3.1.2 through 3.3.1.4.

\subsubsection{Early Warning Signals of Potential Environmental Stress}

of particular concern to environmental scientists and regulators are the long-term responses of organisms to environmental change (e.g., contaminant loading). The more important of these long-term responses (e.g., gruwth and reproductive capacity) respond relatively slowly to 
environmental change (Fig. 6); therefore, by the time these responses are observed in an aquatic ecosystem, undesirable effects (including decreases in biological productivity and diversity) may already have occurred. Such long-term responses may occur over periods of several years or biological generations (Fig. 6), and, within these extended time periods, a variety of natural and man-induced environmental factors can influence the integrity of biological communities. However, because many environmental factors can contribute to and influence an ecological response, the major causes of a long-term ecological change may not be readily identified or quantified by measuring only long-term response variables, such as fish species abundance or diversity (Sect. 3.4.2).

The biochemical and physiological indicators used in this study respond within the same time frame as the environmental changes of concern (primarily water quality) and, because they immediately reflect those changes, serve as early warnings of potential environmental effe ts. With bioindicators, changes observed in the biological integrity of WOC and its tributaries (either beneficial or adverse) can be directly related to specific changes in environmental quality. For example, bioindicators can be used to evaluate (1) the effectiveness of remedial actions and (2) the biological effects of short-term, inadvertent contaminant discharges. Because many of the biological parameters normally measured in compliance monitoring programs (e.g., abundance and diversity of organisms) change relatively slowly, their usefulness as early warning signals of potential environmental change is limited, unless both short-and intermediate-term response indicators are measured concurrently.

\subsubsection{Identification of Mechanisms Underlying Long-Term Effects}

In recent years, several methods have been developed to assess sublethal toxicity; most of these methods have focused on the suborganismal level (Buikema et al. 1982). Many of these biochemical and physiologica; measurements of toxicity have not proven useful because of insufficient information to establish causal relationships between these measurements and responses at the whole organism, population, and community levels (Sprague 1976, Mehrle and Mayer 1980). 
ORNL-DWG 89M-14026R

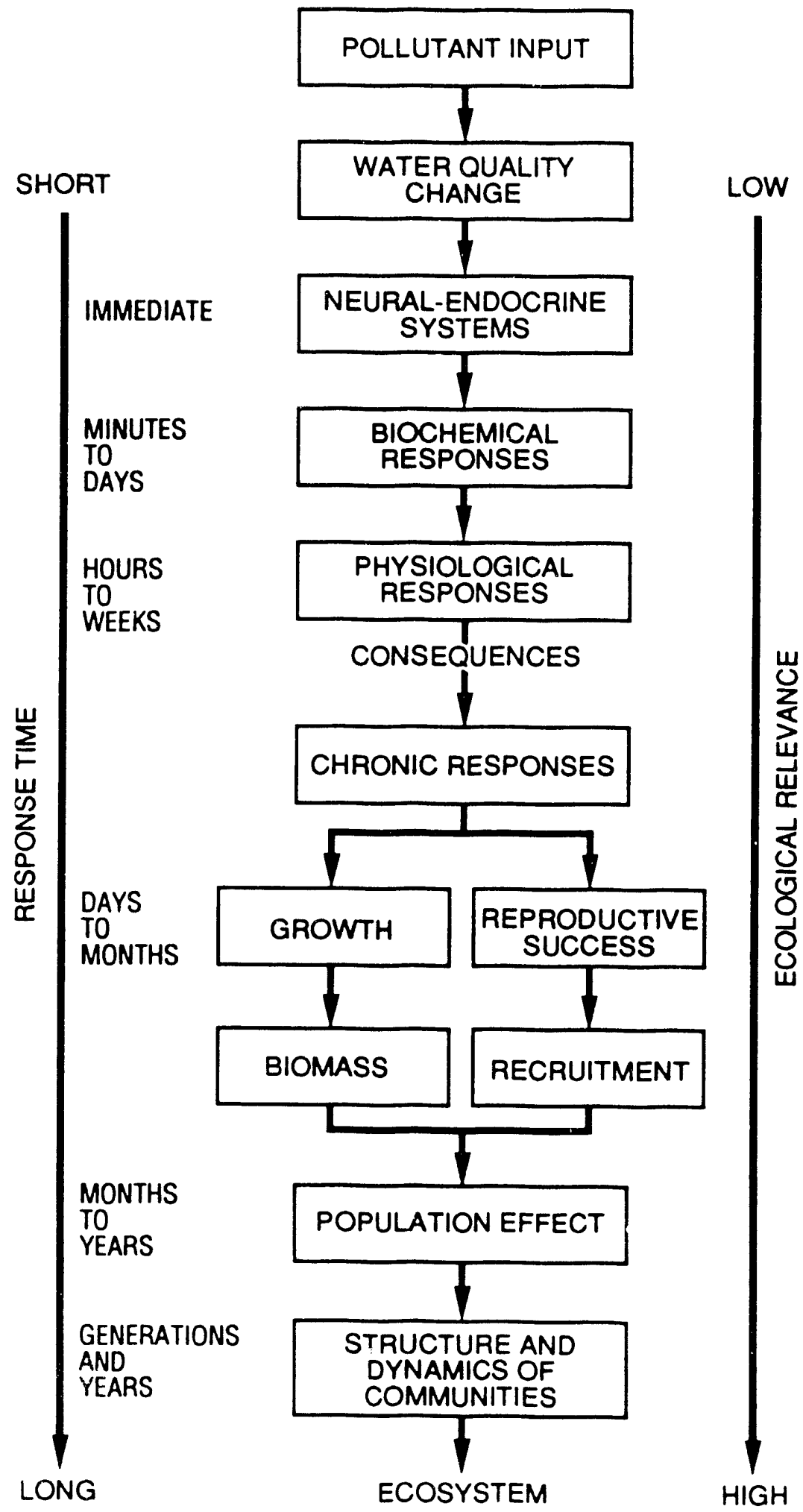

Fig. 6. Levels of biological responses in fish to changes in contaminant levels in surface waters, illustrating the continuum of these responses along gradients of time and ecological relevance. 
In addition, the measurement of only suborganismal responses without concomitant organism- and population-level responses makes it difficult to determine whether biochemical or physiological responses to toxicants are deleterious or are in the normal range of adaptation of the organism (Mount and Stephan 1967).

The bioindicators that will be used in Task 3 represent a gradient of biological response times from relatively short-term to long-term (Fig. 6). Measurements of biological components over this gradient of response times will permit long-term changes in ecological systems to be identified and correlated with the principal factors responsible for those changes. For example, in the initial phases of Subtask 3a, a suite of short-term indicators will be measured in fish, including rapid-response biochemical variables and more intermediate-term responses, such as liver condition, histology of selected organs, and quantity and quality of lipid storage. With this approach, the shorter-term biological responses can be linked to the ecologically relevant long-term responses such as growth, reproduction, and community abundance and diversity (Fig. 6), which are measured as part of Subtask 4b (Sect. 3.4.2). A combination of laboratory experiments, manipulative field experiments, and evaluation of associations in the field can be used to infer cause-and-effect relationships. By establishing cause-and-effect relationships between environmental change, short-term bioindicators, and long-term bioindicators, mechanisms primarily responsible for population- and community-level changes can be identified and quantified.

\subsubsection{Cost-Effectiveness and Ease of Use}

One of the major criteria for selecting the suite of bioindicators to be used in Task 3 is that the amount of effort (e.g., cost and time) allocated to the measurement of each indicator must be justified by the quality and quantity of information provided by that indicator. Each bioindicator screened and selected in Subtask 3a and applied in Subtasks $3 b$ and $3 c$ should be relatively easy to measure and should be cost-effective for application and use in long-term biological monitoring programs such as BMAP. Once the relationship and biological 
significance between short-term indicators (e.g., liver condition) and long-term responses (e.g., growth and abundance) are developed, these short-term indices will provide reliable documentation of the ecological status of WOC watershed and of the effectiveness of the various remedial actions.

\subsubsection{Description of Subtasks}

The bioindicator studies consist of three major subtasks:

(3a) screening and selection of biological indicators for use in

Subtasks $3 b$ and $3 c,(3 b)$ application of selected indicators in the field for long-term instream monitoring and for manipulative field experiments, and (3c) application of selected indicators under controlled conditions in the field and laboratory for testing the effects of water quality conditions on the response of target fish species.

\subsubsection{Subtask 3a: Screening and Selection of Indicators}

Numerous biological indicators have been used to evaluate biological responses to environmental pollutants (Tables 5-7). The primary objective of this subtask is to screen and select a subset of these indicators for use in Subtasks $3 b$ and $3 c$ to (1) characterize and identify aquatic ecological impacts in the wOC watershed, (2) identify contaminant sources that adversely affect stream biota, and (3) evaluate the effectiveness of remedial actions. The groups of bioindicators shown in Table 7 represent the various levels of biological measurements that will be performed on target fish species collected from WOC watershed. At least one indicator at each response level (Table 7) will be measured in initial screening studies to be conducted at four to six sites in the watershed. Measurements will be made of (1) biochemical variables, such as biochemistry of the blood and metabolic variables; (2) tissue- and organ-level indicators, such as energy storage, histopathology, and various fish condition indices; and (3) organism-level response variables, such as growth and reproductive capacity, as discussed in Sect. 3.4.2 (Fig. 7, Table 7). 


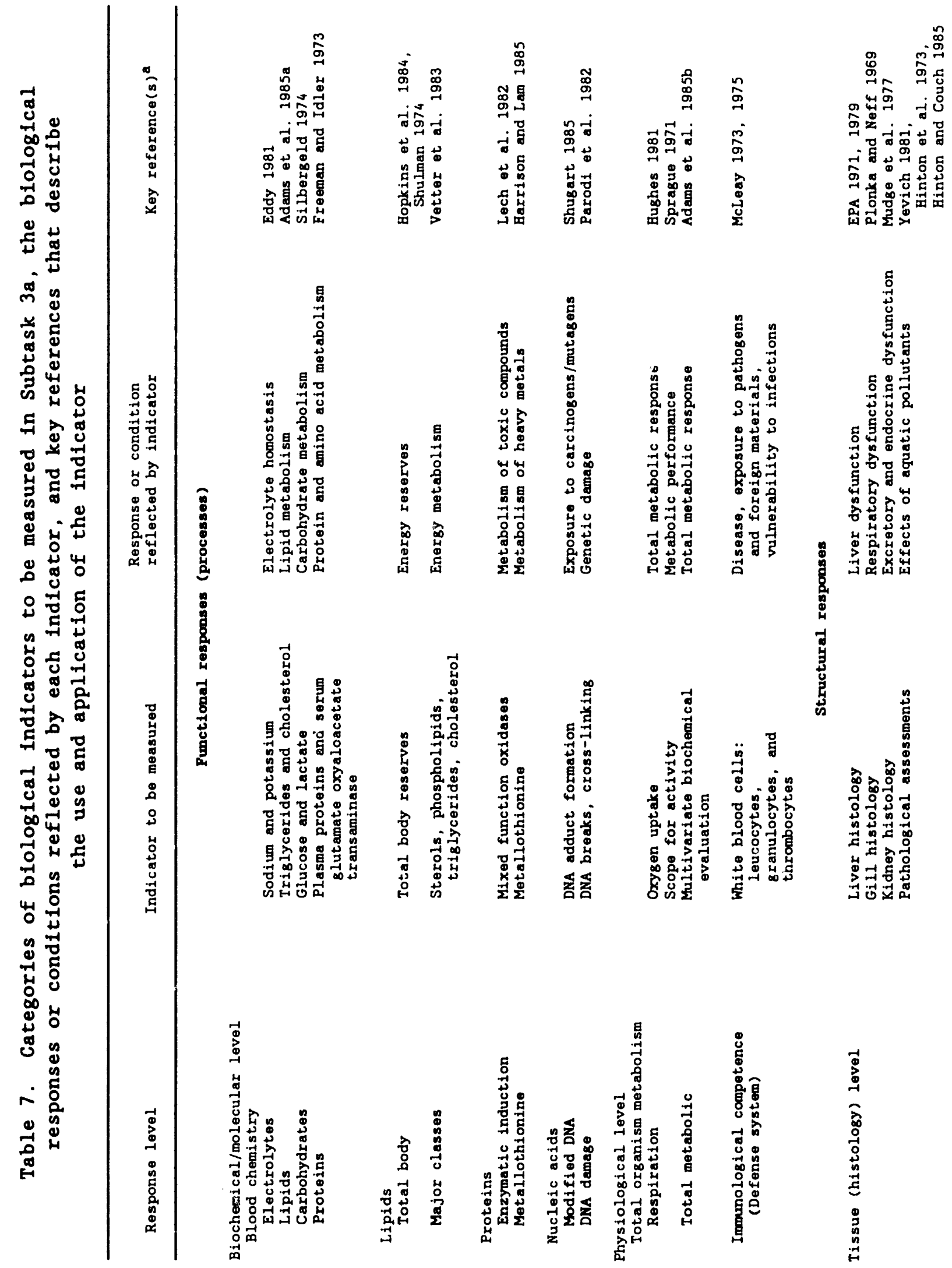




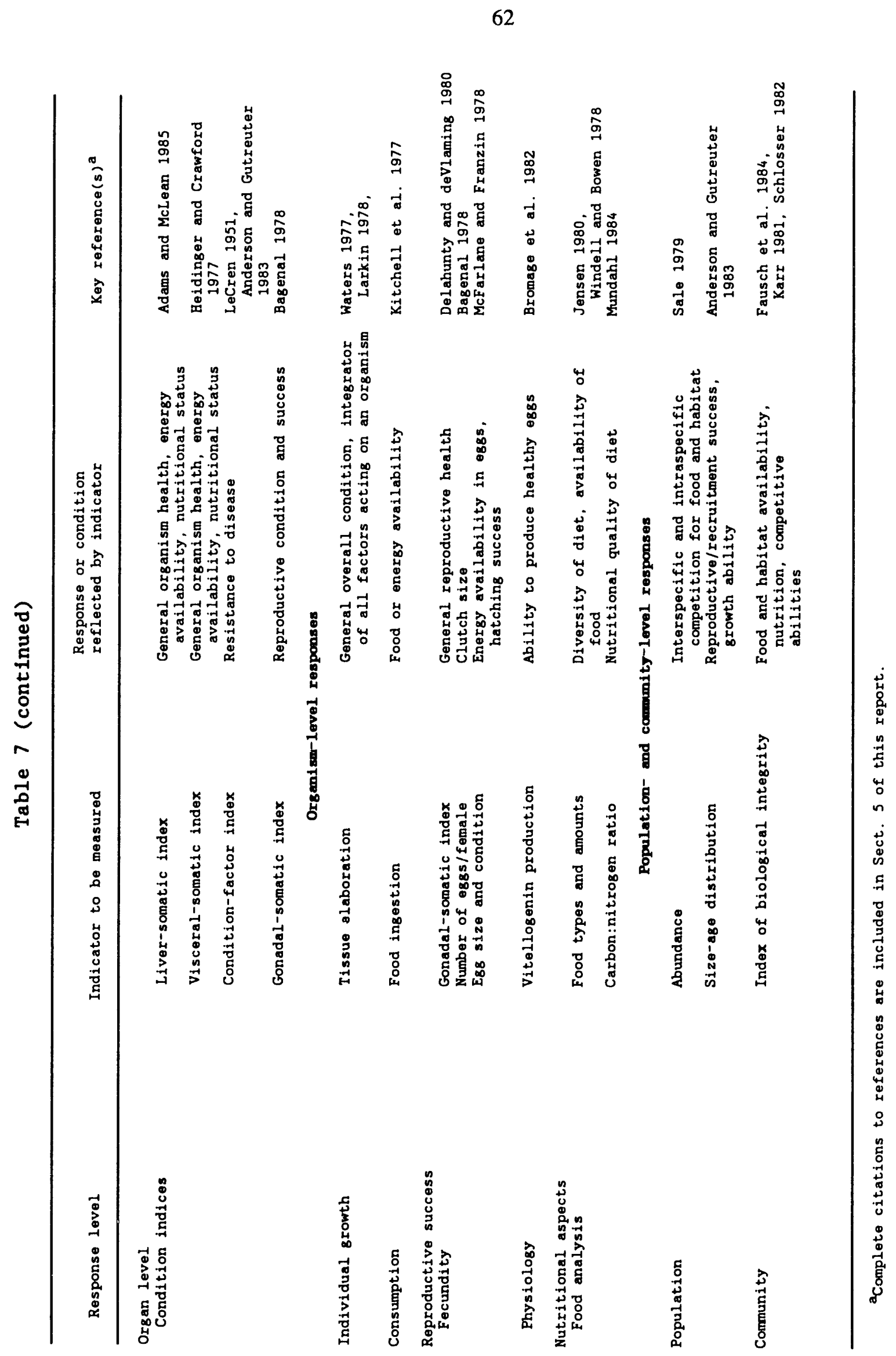


ORNL - DWG 86-1730

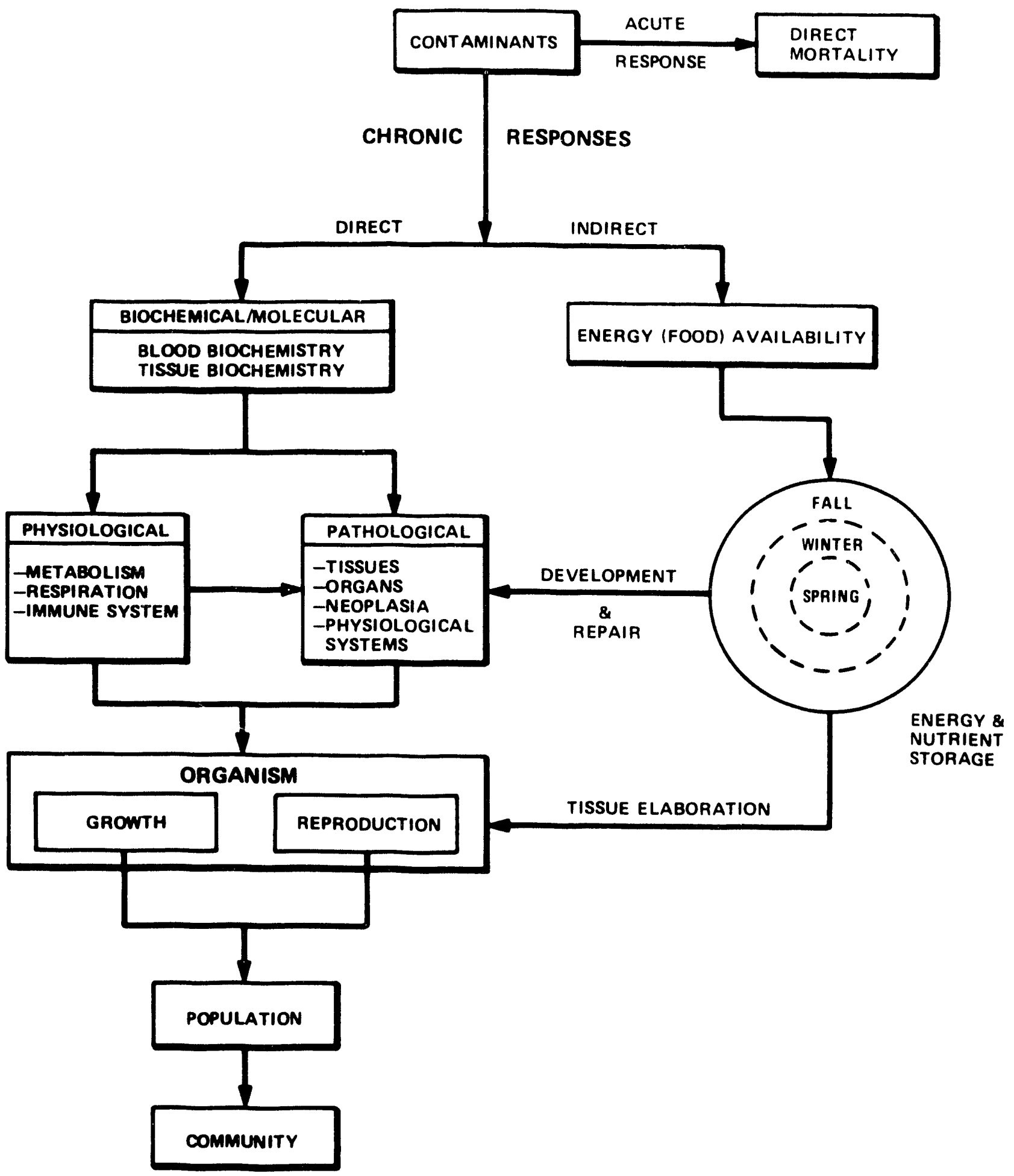

Fig. 7. Chronic-level responses of organisms to sublethal contaminant stress, emphasizing the importance of energy availability (1ipid and nutrient storage pool) in the physiological-, pathological-, and organism-level responses of fish to such stress. 
In conjunction with these measurements, information on fish abundance and diversity will be collected at the same monitoring sites as part of Task 4 (Sect. 3.4.2) and will be used as indicators of population- and community-level responses (Figs. 6 and 7 ). The bioindicators shown in Fig. 6 encompass a response gradient from rapid (biochemical) to relatively long-term (population- and community-level) responses. These bioindicators also fall along a gradient of increasing relevance for evaluating ecological effects. For example, blood biochemical variables are rapid indicators of environmental change, but their potential ecological relevance for evaluating changes in fish abundance and diversity is relatively low. By including measurements along a continuum of response-time indicators, the ecological relevance of short-term responses can be established by identifying cause-and-effect relationships with the long-term, chronic populationand community-level responses (Figs. 6 and 7; Sprague 1976, Mehrle and Mayer 1980). Following these initial studies, a subset of the most informative indicators will be selected for use in the subsequent long-term phase of BMAP.

\subsubsection{Subtask 3b: Application of Biological Indicators in the Field}

The biological indicators selected in Subtask $3 a$ will be used in Subtask $3 b$ to evaluate both short-and long-term responses of aquatic communities to contaminants in the WOC watershed. During the initial characterization and later monitoring phases of BMAP, each indicator will be continually reevaluated as to the usefulness and quality of information provided relative to the objectives discussed in Subtask $3 a$. Some indicators initially identified as important may be deleted, while others may be implemented and incorporated into the long-term monitoring program.

Manipulative field experiments will be conducted to test for contaminant-related effects in selected fish species (e.g., redbreast sunfish and/or bluegill). Live fish collected from uncontaminated (reference) areas and transferred to impacted (i.e., contaminated) areas and $f i s h$ captured in contaminated areas and transferred to reference areas will be confined to small sections of the stream by semipermanent 
enclosures. If enclosures are not feasible, fish will be tagged to identify their origin. To account for the effects of handling stress on transported fish, identical capture and handling procedures will be performed on separate groups of fish confined in enclosures in the same section of stream where they were originally captured. After accounting for handling stress, responses observed in fish transferred from reference areas to affected areas should indicate the level and degree of organism-level effects incurred as a result of contaminant-related stress. Conversely, by examining recovery responses in fish transferred from affected areas to reference areas, the degree of stress or change originally experienced by an organism as a result of contaminant-related stress can be evaluated. Observation of no significant responses in fish transferred to either area would suggest that contaminants were having no effect on individual organisms.

\subsubsection{Subtask 3c: Controlled Experiments}

This subtask will utilize those bioindicators selected in Subtask $3 a$ and applied in the field (Subtask $3 b$ ) to investigate the responses of fish exposed to water from various sites in wOC watershed under controlled conditions. Subtask $3 \mathrm{c}$ has three major components: (1) integration with the toxicity monitoring and bioacrumulation studies (Tasks 1 and 2, respectively); (2) effects testing; and (3) challenge tests.

\section{Integration with other tasks}

As an integrated component of the proposed toxicity monitoring and bioaccumulation studies included in BMAP (Sects. 3.1 and 3.2, respectively), some of the bioindicators selected in Subtask 3a will be measured in the toxicity tests described in Task 1. Physiological and organism-level responses will be related to changes in bioaccumulation through the use of bioenergetics models (Sect. 3.2.5 and Loar et al. 1989). The relationships among the biological indicators, body burden of contaminants, and toxic response will also be examined. With this integrated approach, our bioindicators can be correlated with and related to fish survival, growth, and reproduction (Figs. 6 and 7). 


\section{Effects testing}

Effects testing will involve controlled-response studies conducted in a mobile field laboratory. Fish collected from various areas of WOC watershed and from a reference stream will be placed in metabolic chambers located in this mobile laboratory. During an experiment, the mobile laboratory will be parked beside the study site and water pumped directly from the stream into the metabolic chambers. Metabolism and respiration measurements made on fish at critical periods of the year (e.g., spawning and growth periods) will serve as indicators of physiological response to varying water quality conditions throughout the watershed. Data from these measurements will be used to evaluate the effectiveness of remedial actions and to determine the biological effects of possible short-term effluent releases.

\section{Challenge tests}

Based on the results obtained in Subtasks $3 a$ and $3 b$, challenge tests will be performed to measure the tolerance of fish to stress. According to Wedemeyer and McLeay (1981), an assessment of fish health should not be restricted only to an examination of internal (biochemical and physiological) changes because these responses may not in themselves provide sufficient information for appraisal of the overall condition of an organism. A combination of blood and other tissue analysis (such as histopathology) with standardized stressor challenge tests is needed for a meaningful assessment of fish health. Selected challenge tests may be performed periodically to determine if the ability of fish to tolerate stress changes in response to improvements in water quality. Increased tolerance may indicate, for example, that the probability of survival has been increased (Wedemeyer et al. 1976). Some of the challenge tests that could be conducted include (1) tolerance to hypoxia (Carter 1962), (2) scope of activity (Sprague 1971), (3) disease challenge tests (Wedemeyer and McLeay 1981), and (4) leucocrit stress test (McLeay and Gordon 1977). 


\subsubsection{Sampling Design}

Selection of appropriate sampling sites will be based primarily on three criteria: (1) downstream proximity to contamination sources; (2) availability of fish in sufficient kinds (species), numbers, and sizes to perform the various levels of bioindicator measurements (see Table 7); and (3) location of sampling stations for the instream ecological monitoring (Task 4), toxicity monitoring (Task 1), and bioaccumulation studies (Task 2). Because these tasks complement each other (see Loar et al. 1989, Fig. 5), sampling locations will be coordinated, as appropriate, among Tasks 1-4. The primary fish species used for the bioindicator studies will be redbreast and/or bluegill sunfish. These species are located primarily in pool habitats of wOC and lower MB. Sampling sites for Task 3 will probably be located on (1) WOC below the sewage treatment plant; (2) at the weirs on WOC and MB immediately above their confluence; (3) near WOL; and (4), possibly, in the WOC embayment.

Field sampling will be conducted seasonally with sampling frequency and time of sampling coordinated with the sampling schedules of other related tasks described previously. The number of samples collected at each station will be based on information derived from initial studies. Determination of optimum sample size for each of the indicator levels or groups listed in Table 7 will be based on appropriate statistical procedures applied to the data from Subtask $3 a$ and also on information from other related studies (e.g., Loar et al. 1989; Tables 5-7). For each sampling period and station, selected indicators 1isted in Table 7 will be measured together with the population-and community-level parameters included as part of the instream monitoring task (Sect. 3.4.2).

\subsection{INSTREAM ECOLOGICAL MONITORING (TASK 4)}

The objectives of the instream ecological monitoring task are (1) to characterize spatial and temporal patterns in the distribution and abundance of the benthos and fish populations in wOC watershed; (2) to identify contaminant sources that adversely affect stream biota, including differentiation between point sources and nonpoint (or area) 
sources, wherever possible; and (3) to monitor these populations and document the effects on community structure and function from operation of new wastewater treatment facilities, from improvements in waste management operations, and from implementation of remedial actions directed at area source control. Intensive sampling to characterize the benthos and fish communities will be conducted during the first year. Based on the results of these and other studies (see Sects, 3.1 and 3.3), sampling frequencies and locations may be modified, as appropriate, during the monitoring phase of the program.

The instream monitoring task will involve field sampling of the benthic invertebrate and fish populations in wOC and selected tributaries and in wOL. The tributaries included in this task are First Creek, Fifth Creek, NWT, and MB (Fig. 2), all of which receive effluent discharges from ORNL facilities. Some tributaries may also receive contaminants from area sources (e.g., discharge of ${ }^{90} \mathrm{Sr}$ from SWSA 3 to NWT; Stueber et al. 1981).

Sites in WOC embayment and the Clinch River were excluded from the scope of the instream monitoring task for several reasons. First, a comprehensive survey was recently conducted of the aquatic biota in both the embayment and in the $\mathrm{Clinch}$ River above and below the confluence with WOC (Fig. 1; Loar et al. 1981a). This 1979-80 survey included (1) biweekly sampling of phytoplankton and zooplankton; (2) weekiy sampling of ichthyoplankton; and (3) monthly sampling of periphyton, benthic invertebrates, and fishes during the period from March through October. Sampling frequencies were reduced from biweekly to monthly and from monthly to bimonthly during the remainder of the year (Loar et al. 1981a, Table 3.1). No statistically significant differences in the composition and abundance of phytoplankton, zooplankton, and benthos between the upper and lower $C$ inch River sites were observed. The ichthyoplankton, periphyton, and adult fish communities at the two Clinch River sites were also similar, based on qualitative comparisons. Second, the ecology of the Clinch River tailwaters from Melton Hill Dam to just below the confluence with Poplar Creek (a distance of $\sim 21 \mathrm{~km}$ ) has been described in several major surveys conducted since 1974 (Project Management Corporation 1975; Exxon Nuclear, Inc., 1976; Loar et 
al. 1981b). Although sampling methods varled among the surveys (see review by Loar et al. 1981b), the results obtained in the 1979-80 survey were comparable with these earlier studies (e.g., see the benthos discussion in Loar et a1. 1981a, Sect. 4.3.5).

Another reason for limiting the scope of the instream monitoring task in BMAP is that the discharge from WOC is significantly diluted by the Clinch River. Based on water quality data collected weekly from April 1979 to January 1980 at White Oak Dan (M. A. Montford, T. W. Oakes, and W. F. Ohnesorge, Oak Ridge National Laboratory, unpublished data) and on average flows for the Clinch River and WOC, the effects on Clinch River water quality, assuming complete mixing, were estimated by Boyle et al. (1982) to be negligible. Even with no mixing, average concentrations at the dam do not represent degraded water quality when compared with EPA criteria for protection of aquatic 1 ife or with background levels in wOC north of Bethel Valley Road (Fig. 1; Boyle et al. 1982).

Finally, a comparison of the blological communities inhabitating WOC below ORNL in 1979-80 (Loar et al. 1981a) and those found during the synoptic survey of 1985 (Sect. 2.1.4) suggests that no significant additional degradation in water quality (nonradiological component) has occurred over the 5-year period. Compared with the earlier survey, the 1985 sampling program provided a greater resolution of stream areas currently impacted by ORNL operations and emphasized the need to prioritize efforts toward identification of the contaminant sources to biota in these areas (e.g., lower Fifth Creek, MB, and WOC below ORNL). Studies of WOC embayment and the Clinch River are included in the work scope of Tasks 2 and 7; further studies to monitor the biological communities of these areas are unnecessary and would only divert efforts from those impacted areas of the watershed that require much greater study.

\subsubsection{Subtask 4a: Benthic Invertebrates}

Analysis of the structure and function of benthic invertebrate communities provides a useful tool for evaluating the ecological effects of effluent discharges on streams (Cairns 1974, Platts et al. 1983). 
Because of their low motility and relatively long life cycles (several weeks to more than 1 year), benthic invertebrates integrate short-ierm changes in the physicochemical environment of streams (e.g..

Hynes 1984). Many benthic speries spend a considerable portion of their life cycle on or in sediments, resulting in potentially long-term exposure to contaminants that accumulate in stream sediments. Because sediment-bound contaminants not evident in solution may be biologically available to produce effects on organisms in contact with the sedimerts, biological monitoring that includes studies of benthic organisms can be considerably more informative than methods that rely solely on water quality analyses.

\subsubsection{White Oak Creek and Tributaries}

Benthic invertebrate populations will be sampled monthly from designated riffle areas at 15 locations in streams in wOC watershed, including 6 sites on WOC, 3 sites on MB, and 2 sites on each of the following tributaries: NWT, First Creek, and Fifth Creek (Fig. 8). Additionally, one site in WOL (WCK 1.1) will be sampled bimonthly. The results obtained during the first year will be used to evaluate the possibility of reducing sampling frequency and the number of sampling locations. In addition to upstream control sites, several reference streams, which are located both within and outside of ORR will be sampled quarterly; the results will be compared with those for the upstream sites on each steam or, where appropriate, with those for downstream sites. Use of additional reference streams with lessfrequent sampling will provide a good comparison of natural seasonal variability in the benthic invertebrate communities occurring in unimpacted streams of this area. To accurately estimate species richness, a variety of microhabitats (e.g., leaf packs, undercut banks, pools, riffles outside the study riffles) will be qualitatively ampled at each site in WOC watershed and in the reference streams in March-April 1987.

Three randomly selected bottom samples will be taken at each site with a Surber sampler $\left(0.09 \mathrm{~m}^{2}\right.$ or $\left.1 \mathrm{ft}^{2}\right)$ fitted with a $363-\mu \mathrm{m}-\mathrm{mesh}$ collection net. The samples will be preserved in 808 ethanol, which 


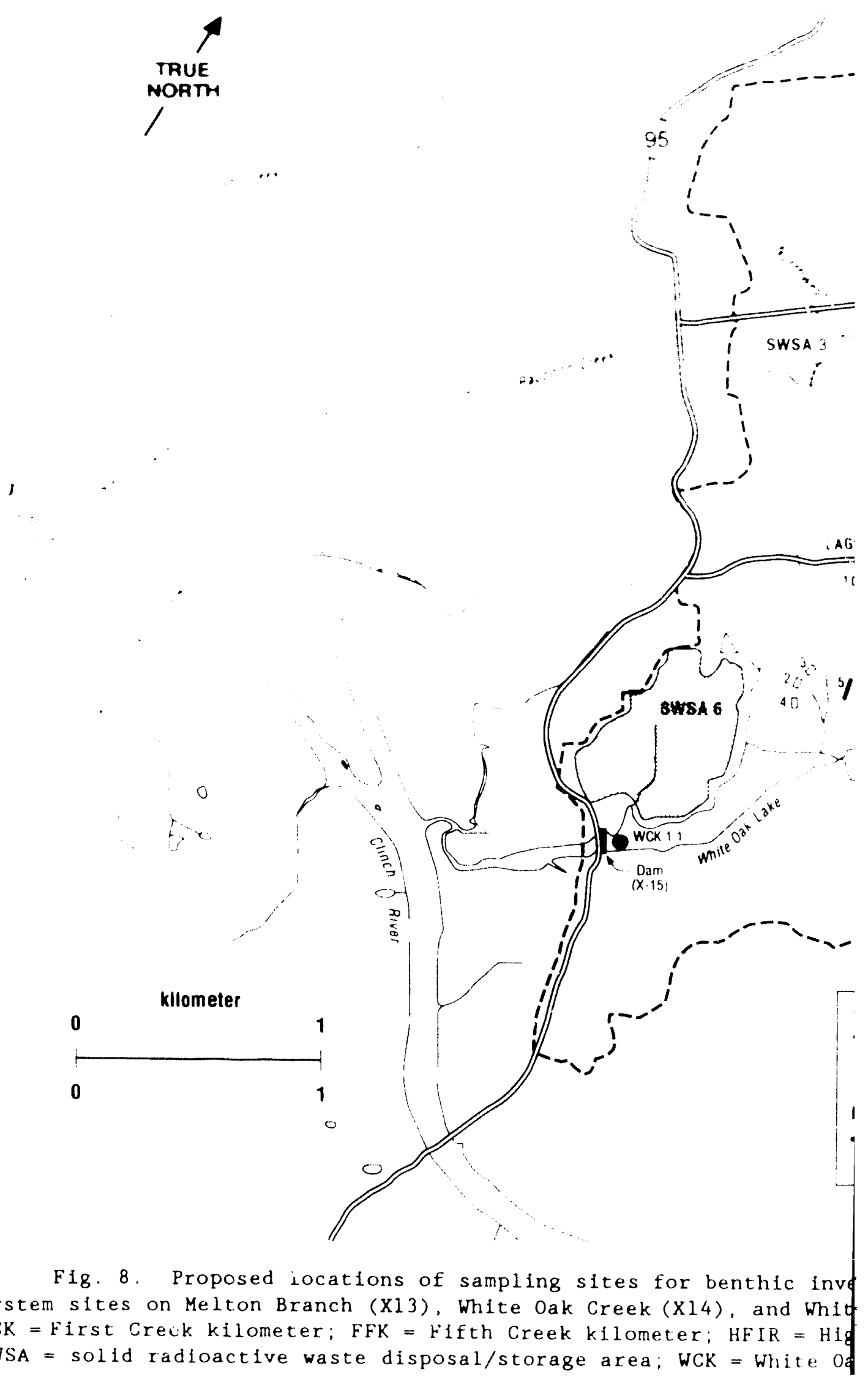


ORN OWE, 91M 14119

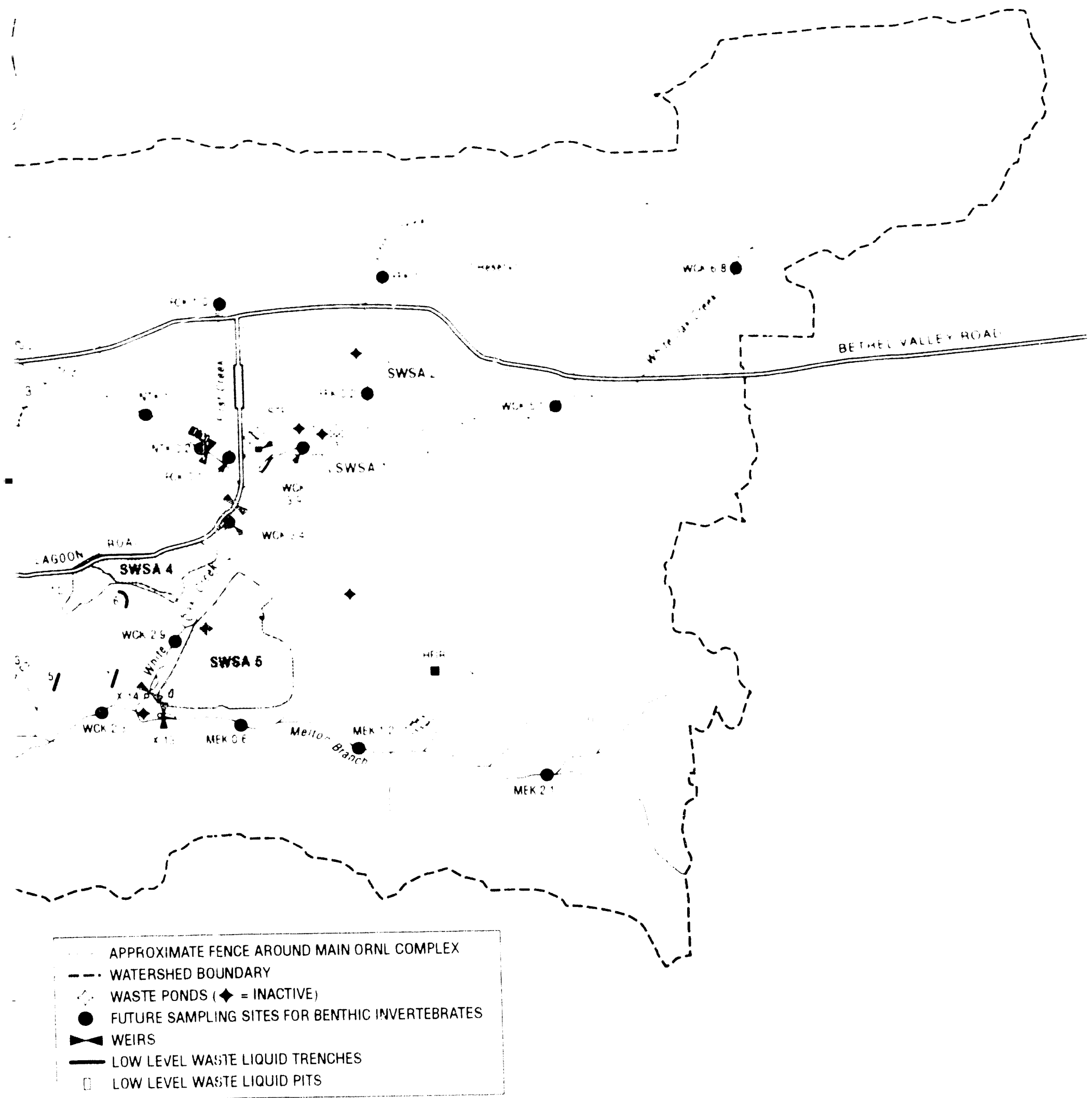

invertebrates and fish in White Uak Creek watersied; Nailuial Pollutant Discharge Filmination 1 White Oak Dam (X15); and the liquid and solid radioactive waste disposal/storage areas.

= High Flux Isotope Reactor: MEK = Melton Branchkilometer; STP = Sewage Treatment Plant: -ite Oak Creek kilometer 
will be replaced with fresh 80 o ethanol within 1 week after collection of the samples. In the laboratory, benthic organisms will be separated from the debris in white enamel pans and identified to the lowest practical taxonomic leve1; oligochaetes will be identified to family. A blotted wet weight of each taxon will be obtained to the nearest $0.1 \mathrm{mg}$. Additionally, one to five target species will be selected for estimating secondary production via direct methods. For these selected species, head width or body length will be measured to the nearest $0.1 \mathrm{~mm}$. Individuals will be sorted into size classes and weighed (blotted wet weight) to the nearest $0.01 \mathrm{mg}$ for each size class.

Nonparametric statistics will be used to compare species richness, density (total number of individuals per $0.09 \mathrm{~m}^{2}$ ), and species diversity $\left(H^{\prime}\right)$ between the stations on WOC, the tributaries, and their controls. Estimates of secondary production for the target species will be obtained directly by the size-frequency method (Hynes 1980, Waters and Hiokenstrom 1980); for the remaining species, secondary production will be estimated indirectly from published data on production:biomass ratios $(P: B)$ (Waters 1977, Kruger and Waters 1983, Benke 1984). Where appropriate, water quality and ambient toxicity data will be used in data interpretations.

\subsubsection{White Oak Lake}

Benthic macroinver cebrates of WOL will be sampled bimonthly during the first year across a transect located $\sim 100 \mathrm{~m}$ above the dam. Recent data on the benthic invertebrates of WOL indicate a relatively simple community dominated by chironomids, with peak densities occurring in

both thi : family and the total community in late spring and early summer an 1 in iate summer (Loar et al. 1981a); thus, bimonthly sampling should provide a good characterization of the benthos. Five samples will be taken across the transect at $-10-\mathrm{m}$ intervals with a hand-operated Ponar dredge having the dimensions $15 \times 15 \times 15 \mathrm{~cm}$. The samples will be placed in a $363-\mu \mathrm{m}$-mesh net and washed in order to reduce the volume of sediment. The samples will then be preserved in 808 ethanol, returned to the laboratory, and processed in the same manner as the samples taken from WOC, including replacement with iresh ethanol and selection and 
analysis of one to five target species for estimating secondary production via direct methods.

Nonparametric statistics will be used to compare species richness, density, and diversity between sampling zones. Estimates of secondary production of target and nontarget species will be obtained by the same methods employed for WOC.

\subsubsection{Subtask 4b: Fishes}

The majority of the studies included in BMAP focus on fish and include studies at all levels of detail from individual tissues to rommunities. Fish communities are composed of species that represent several trophic levels, but the species of greatest significance to man (e.g., bluegill and redbreast sunfish in the WOC drainage) are at or near the end of food chains. Consequently, they integrate the effects of water quality and habitat degradation on lower trophic levels (e.g., benthic invertebrates) that are utilized for food. Because of these trophic interrelationships, the health of fish populations is orten used as an index to water quality (e.g., Weber 1973, Greeson et a1. 1977, Karr 1981). Moreover, statements about the condition of the rish community are better understood by the general public (Karr 1981).

\subsubsection{White Oak Creek and Tributaries}

Fish communities at the 15 sites included in the benthos sampling program (Sect. 3.4.1 and Fig. 8) will be sampled three times (April, August, and December) during the first year to estimate both population size (numbers and biomass per unit area) and production by species. Sampling will be conducted over designated reaches $-50-150 \mathrm{~m}$ in length, depending upon the size of the stream and the density of fish. In addition, qualitative sampling above and/or below each study reach will be conducted in the spring and fall.

All sampling will be conducted by using one or two Smith-Root Model 15A backpack electrofishers. These units utilize self-contained, gasoline-powered generators capable of delivering up to $1200 \mathrm{~V}$ of pulsed

direct current. Population estimates will be based on the removal method (Carle and Strub 1978) with a minimum of three consecutive passes at each site. Fish will be anesthetized with tricaine methanesulfonate 
(MS-222), identified, measured to the nearest $0.1 \mathrm{~cm}$ (total length), weighed to the nearest $0.1 \mathrm{~g}$ (fur fish $<100 \mathrm{~g}$ ) or to the nearest gram (for individuals $>100 \mathrm{~g}$ ), and returned to the stream. For target species (bluegill and redbreast sunfish; Table 3 ), scales will be taken for age determination. The instantaneous growth rate method (Ricker 1946) will be used to calculate annual production, by year class, of the target species. For all other species, production will be estimated by the method of Garman and Waters (1983).

By using the approach and procedures described here, data will be available to estimate paramcters at both the community level (species diversity, production, and abundance) and the population level (length-weight relationship, production, and abundance), as well as for individual age classes of the target species population (instantaneous growth rates and mortality rates, mean condition factor, production, and abundance). However, information on only two parameters, age (from scale analyses) and condition (from length and weight measurements) is available for individuals within the population. To correct this deficiency and to strengthen the correlation between the instream monitoring task, with its focus on communities and populations, and the bioindicator task (Task 3), with its focus on the individual, several additional parameters (e.g., growth and reproductive success; see Fig. 6) will be measured.

Growth rates of individuals in the population, for example, will be estimated by periodic sampling of tagged fish (bluegill and redbreast sunfish). Fish will be collected from sites near large weirs on wOC (just above WC, 3.4 and at WCK 2.6 above the confluence with MB) and on MB (MEK 0.2). Sites in WOL and WOC embayment may also be included, depending upon recapture efficiency and centrarchid abundance, respectively. The control site will be Brushy Fork, a tributary of Poplar Creek. Yearling and older individuals will be collected by electrofishing and then weighed, measured, and tagged. Sampling will be conducted approximately quarterly to minimize the effects of electroshocking on growth. Continuous strip-chart recordings of water temperature will be obtained with a Peabody Ryan Model J90 thermograph at each site. 
Another parameter of individuals in a population is fecundity, or the number of ripening eggs in the female just prior to spawning (Bagenal 1978), which provides a measure of potential reproductive success. Fecundity of either bluegill or redbreast sunfish will be estimated by gravimetric subsampling (Bagenal and Braum 1978) at the same sites selected for the individual growth rate studies. The number of eggs per female will be expressed as a function of fish length and age at each site.

To provide information on trophic interrelationships that can be used to construct community food webs and to evaluate biotic integrity (e.g., Karr et al. 1984), an analysis of the food habits of fishes will be conducted. The evaluation of feeding preferences will be conducted on the same species used in the growth rate and fecundity studies. The quality and quantity of food consumed, including variability in composition as a function of sampling location and season, will be determined to evaluate the nutritional importance of food from various sites within WOC watershed. Stomachs will be flushed by inserting a small plastic tube $(0.5 \mathrm{~cm}$ OD) into the gullet and repeatedly injecting water into the stomach by using a rubber bulb with one-way valves. This nondestructive sampling technique is the same as that used by Loar et al. (1985) and is similar to the procedure described by Seaburg (1956). Taxonomic identification of stomach contents will be made to the lowest practical taxon (genus, if possible). Food quality will be evaluated, using carbon and nitrogen analyses on stomach contents. Additional, but more qualitative, sampling of other species may also be required to establish trophic relationships that are poorly documented in the literature.

\subsubsection{2 uitu Oak Lake}

The size of the fish populations (numbers and biomass) in WOL will be estimated in the summer of 1986, using mark-recapture techniques. Estimates will be obtained for those species composing a significant portion of the total community biomass. Data derived from this population survey will be used to estimate the proportion of the total radioactivity in wOL that is present in fishes. These results and 
similar information obtained on other communities in the lake (e.g., macrophytes, benthic invertebrates) will be used in Task 6 to determine the total amount of radioactivity in the biotic and abiotic (water and sediments) components of the lake ecosystem.

\subsubsection{Subtask 4c: Interpretation of Blotic Changes}

The long-term goal of BMAP is to restore the WOC watershed to a condition suitable for (1) growth and propagation of fish and aquatic life and (2) livestock watering and wildlife (TDPH 1978). Since the criteria for these conditions are not specifically stated, this goal must be based on the condition of the least disturbed streams of a similar type in the surrounding region. An unfortunate fact of nature is that there is considerable variation in the structure of stream communities even under natural, unimpacted conditions. Under pristine conditions, species diversity levels vary greatly from stream to stream and with time and location within a given stream. Thus, any evaluation of the condition of WOC must be based on a thorough understanding of the natural temporal and spatial variability.

Ecological theory may provide some insight into the consequences of the interacting processes at work in both impacted and unimpacted streams. Pristine streams unaffected by human activity are subjected to many types of acute disturbances that may produce mortality, including floods, aroughts that cause the stream to dry up, and seasonal drops in $\mathrm{pH}$. Impacted streams, such as WOC, are subjected to these disturbances plus those resulting from toxic chemicals. Likewise, both types of streams are subject to chronic conditions that may affect growth and reproduction, such as temperature level and variation, nutrient loading, natural $\mathrm{pH}$, and other water quality conditions. In addition to these factors, the growth of organismis in impacted streams may also be affected by the presence of toxic chemicals at levels that do not produce mortality.

The effects of both acute, mortality-causing conditions and chronic conditions that affect growth have been integrated in a general theory that predicts community structure based on the interaction of growth rates and disturbance (Huston 1979). Use of ecological models based on 
this theory can help separate the effect of natural conditions on stream community structure from the impact-induced effects.

The first step in this process will be to use data from control streams to develop a model of the response of stream communities to naturally occurring disturbances and variation in growth conditions. Once this has been done, the effects of natural conditions can be separated from impacts resulting from ORNL operations, and the probable cause of the adverse impact can be determined. With this level of understanding, prediction of the effects of specific types of remedial actions may be possible.

\subsection{ASSESSMENT OF CONTAMINANTS IN THE TERRESTRIAL ENVIRONMENT (TASK 5)}

The objectives of the biological monitoring program for terrestrial organisms are (1) to document what radioactive and organic contaminants are present in the terrestrial environment at ORNL; (2) to examine the potential for mobility and availability of these contaminants to terrestrial biota; and (3) to select the appropriate organisms and monitoring approaches for more-detailed biological monitoring, as needed. The information from early stages of the terrestrial study will be used to evaluate the hazard to wildlife, vegetation, and humans resulting from radionuclides and organics. Critical pathways of contaminant exposure will be identified.

A detailed monitoring program will be developed according to the findings in the initial phases so that attention will be focused on 1:hose contaminants that are toxic, persistent, present in elevated concentrations, and capable of movement through critical pathways to produce adverse ecological or human health effects.

\subsubsection{Subtask 5a: Radionuclides}

The studies summarized in Sect. 2.2.1 indicate that the types and relative amounts of radionuclides in the environment have been well characterized for the primary radioactive disposal sites in the ORNL area. With few exceptions, transfer coefficients for radionuclides to plants and animals, relative to soil and water, are quite low; thus, systematic soil surveys for radionuclides followed by application of 
existing transfer coefficients will be used to provide estimates of contaminant levels in biota. These calculations will be supplemented, as appropriate, with residue analyses of animals and vegetation to verify the scope of potential problems identified on the basis of transfer coefficients.

Departures from this approach of using soil and surface water measurements as the best predictors of radionuclide residues in biota occur under two special circumstances. One is for those radionuclides for which insufficient data are avallable to predict transfer coefficients, and the other is for those radionuclides that demonstrate ready availability to biota plus incorporation into tissues. Tritium falls in the former category; technetium and strontium show the latter characteristics.

Coilectively, the studies of small mammals inhabiting contaminated sites at ORNL indicate that levels of radioactivity are not high enough to cause gross, readily observable, adverse effects on individual animals or to populations inhabiting the ORNL environs. However, the techniques of wildlife biologists and clinicians 20 to 30 years ago were not as sensitive as those available today, and additional releases of radionuclides have occurred since these studies were conducted. The use of sensitive biochemical indicators of toxicant exposure (e.g., DNA damage) can now provide useful information on the radiation exposules of animals inhabiting contaminated sites. Even if exposure is not sufficient to impact these organisms directly, the data will permit assessment of the probability for exposure of humans who venture into contaminated areas.

Despite the relatively minor role of biota in the mass transport of radionuclides, specific taxa may provide an opportunity for evaluating the potential for significant direct human exposire to radionuclides. Both freshwater turtles and waterfowl are sought by people for food. The vagility of both humans and these prey prevents complete proscription of consuming any animal that spends time on contaminated sites at ORNL.

In Iight of these considerations, the terrestrial component of the biomonitoring program for radionuclides emphasizes the following: 
1. Radiological characterization of soils in potentially contaminated yet poorly surveyed areas (e.g., MB), with subsequent application of transfer coefficients for risk analyses of specific radionuclides present. This analysis will provide a means of identifying potential problems and will provide criteria for eliminating specific radionuclides from intensive monitoring efforts.

2. Radioecological studies of relatively abundant radionuclides for which sparse data are available (initially tritium, possibly strontium and technetium).

3. The use of DNA damage as a biochemical indicator of radiation exposure for small-mammal populations at contaminated sites, rather than relying on less sensitive bionomic and clinical measures of radiation exposure.

4. Analysis of waterfowl and turtles as critical biologicai pathways potentially resulting in human exposure to mobile radionuclides that bioaccumulate.

5. Relialce on past studies at ORNL as well as on the known history of contaminant discharges to select those contaminants for monitoring that are likely to be present and problematic and/or have the potential for high. impact if present. No effort is made to undertake exhaustive trace chemical analyses of plants, animi!ls, and soil due to the prohibitive cost and the inefficiency of this approach to ervironmental risk analysis.

6. Field sampling of animals that is highly integrated wi'n studies of organic contaminants to maximize the amount of data obtained from each animal on the concentrations of both organic and radioactive contaminants.

7. The inherent assumption that details of the proposed terrestrial task will be developed on the basis of the data obtained during early scoping and analysis phases of the program. The scoping studies will be used to select chemicals, pathways, organisms, and approaches appropriate for the subsequent phases of the program. This iterative approach to terrestrial monitoring is a result of the need to apply improved methods now available to analyze for 
contaminants in terrestrial biota; however, preliminary data are needed before these methods can be used with assurance that they are both appropriate and applicable. The effort invested early in the scoping phase to obtain preliminary data by using new methods could prove substantially beneficial for the later, more routine monitoring activities.

\subsubsection{Subtask 5a, Part 1: Radiologic Characterization and Risk Analysis of Melton Branch Floodplain and the White Oak Creek Dralnage Area}

A systematic survey of soil and sirface water is needed in the MB floodplain and in areas bordering wOC to determine which radionuclides are present and at what concentrations. Initially, neither plants nor animals will be collected for analysis; instead, existing data on radionuclides in biota, including deer, will be evaluated. After the inventory of radionuclides has been completed, published transfer coefficients for prevalent radionuclides will be used to calculate maximum exposure to biota and to hypothetical human inhabitarts in the entire watershed, including both MB and WOC. Radionuclide dosages to deer and other critical species will also be calculated. These calculations will provide a basis for eliminating specific radionuclides from further study because even their maximum concentrations in the watershed soils would result in a negligible radiation dose to animals and humans relative to natural background. Conversely, these data will be used to identify radionuclides for which biological residue analyses are needed, either because of the inadequacy of radioecological data or because levels of contamination may approach or exceed radiation dose limits.

\subsubsection{Subtask 5a, Part 2: Radioecology of Tritium}

Aralysis of tritium behavior in the terrestrial environment will be carried out at selected sites in the watershed. From 1964 to 1980, more than 137,000 Ci of tritium was released to the Clinch River over White Oak Dam. Recent measurements show concentrations in floodplain soils bordering WOC and $\mathrm{MB}$ as high as $100 \mu \mathrm{Ci} / \mathrm{L}$ water. The magnitude of 
these releases requires a better understanding of the fate of tritium within the terrestrial ecosystems.

An initial survey of groundwater, surface waters, and soil will be conducted in the spring of 1986 in the area surrounding waste disposal areas in order to identify the best sites to measure tritium in soil, vegetation, and air. Exchanges of tritium between vegetation and air and between soil and air will be conducted through the summer and fall of 1986. These data will be used to evaluate the relative ecological and human health import of this low-level beta emicter.

\subsubsection{Subtask 5a, Part 3: Biochemical Indicators of Radiation Exposure}

Data on body burdens of radionuclides in mammals inhabiting the ORNL area will be complemented by quantitation of DNA damage in tissues of live-trapped mammals. DNA damage has been proposed as a useful parameter in screening chemicals shown to produce genotoxicity in mammalian cells. The alkaline elution technique (Erickson et al. 1980, Daniel et al. 1985) has proven to be a powerful and sensitive analytical method for measuring DNA damage, such as single-stranded breaks, DNA-protein cross-lirking, and DNA interstrand cross-linking. The measure of DNA damage has been shown to be a nonspecific biochemical response to exposure from a variety of genotoxic chemicals and physical agents .

Measurement of DNA damage in mammalian cells will be used in a monitoring program for both radionuclides and organic hazardous contaminants (Sect. 3.5.2). By including animals (1) from areas known to be contaminated with elevated amounts of radionuclides but with background levels of organics, (2) from areas high in organics but with background levels of radionuclides, and (3) from areas that have both elevated radionuclides and elevated organics concentrations, a reference data base will be established for rapid determination of the magnitude of exposure for terrestrial animals to chemical contaminants in the environment. The measurements of DNA damage will be complemented by biochemical analyses of blood for evidence of PAH exposure, as described in Subtask 5a, Part 4. 
The initial phases of this study, which are to be completed in 1986, involve analysis of liver tissues from woodchucks (Marmota monax) inhabiting the area around the Equalization Basin, which is a settling pond (Pond 3524) for liquid radioactive waste at ORNL. Approximately $150 \mathrm{Ci}$ of radioactivity is contained in the Equalization Basin; thus, the resident woodchucks, which consume vegetation on the banks and burrow around the basin, undoubtedly receive a substantial exposure to internal and external radiation. The wide distribution and high population densities of woodchucks in the area make them especially promising candidates for a sampling program. The fact that $M$. monax is an herbivore with a life-style involving substantial soil contact and with a long life span laverage life expectancy of from 4 to 6 years (Hamilton 1934, Grizzel 1955)], coupled with the fact that individual woodchucks have rather limited home ranges, commends the animal for biomonitoring.

During the spring of 1986, the Equalization Basin will be surveyed for entrances to woodchuck burrows. These will be flagged, the population density will be estimated, and an appropriate number of traps will be baited with apple. An intensive trapping effort will be conducted, not only to obtain test specimens but also to eliminate woodchucks from the area, because their burrowing activities threaten the integrity of thc retaining wall for the Equalization Basin.

Captured woodchucks will be taken to the laboratory and anesthetized, and $2 \mathrm{~mL}$ of blood will be drawn from the tail for organic analyses. The animals will then be sacrificed, liver samples will be taken, and the carcass will be frozen until whole-body counts can be made. Animals will be aged, sexed, and body parts will be processed for beta and gamma counting. Data on body burdens of radionuclides, DNA damage, and organic residues will be compared with data for animals captured from a reference area (or areas). The results of this initial study of DNA damage in woodchucks will provide an early evaluation of the utility of this approach for monitoring exposure of small mammals to radiation at contaminated sites in the watershed. If the data indicate that this approach is feasible, then studies in 1987 will involve trapping mammals in other areas of contamination and implanting 
dosimeters for quantifying radiation exposure. Soil, vegetation, and water samples will also be collected and analyzed for radionuclides and selected organics.

Overall, this approach has the potential for rapidly providing information on the bioavailability of toxicants to mammals inhabiting a contaminated site and represents a considerable improvement over more conventional ecological and clinical measures of toxicant exposure.

\subsubsection{Subtask 5a, Part 4: Critical Pathway Analysis--Freshwater Turtles}

The role of freshwater turtles in the dispersal of radionuclides from the sediments of wOL to the surrounding terrestrial environment will be examined during 1986 and 1987. Whole-body and specific tissue burdens of radionuclides will be determined. Special emphasis will be given to ${ }^{90} \mathrm{Sr},{ }^{137} \mathrm{Cs},{ }^{60} \mathrm{Co}$, and ${ }^{75} \mathrm{Se}$, because preliminary findings ( $\mathrm{L}$. Meyers-Schöne and B. T. Walton, Oak Ridge National Laboratory, unpublished data) indicate that these radionuclides are found in turtles collected from wOL.

Turtle species will be trapped by using hoop nets, wire-mesh cylindrical funnel traps, and 1 -in.-wire-gage box traps (Tomahawk Company). Preliminary trapping in White Oak Lake (L. Meyers-Schöne, Oak Ridge National Laboratory, unpublished data) showed the yellow-bellied slider (Pseudemys scripta) to be the most abundant small turtle in the lake. Other turtles trapped were the stinkpot (Sternotherus odoratus), snapping turtle (Chelydra serpentina), midland painted turtle (Chrysemys picta marginata), and Eastern spiny softshell (Trionyx spiniferus). The yellow-bellied turtles, stinkpots, and spiny softshelled turtles will be the focus of biomonitoring studies because of their abundance, the relative ease of trapping and handling, and their degree of contact with sediments.

Whole-body counts of gamma-ernitting radionuclides will be obtained. Turtles will then be dissected and sexed; stor $7 \mathrm{ch}$ and intestinal contents will be removed and examined for information on food habits. Body components will be separated into bone, tissue, plastron, carapace, gastrointestinal tract, and miscellaneous internal organs. These 
subsamples will be counted for gamma-emitting radionuclides and then prepared, as appropriate, for counting beta emitters. In addition, fresh liver samples will be taken and prepared for analysis of DNA damage, thus providing an additional means of assessing the bioavailability of radionuclides at a contaminated field site. Data on body burdens of radionuclides and on DNA damage will be evaluated in the context of the radionuclide inventory of WOL (Sect. 3.6.2.2).

This study of radionuclides in turtles will demonstrate whether these animals can in fact be useful organisms to evaluate the bioavailability of radionuclides known to be present in aquatic sediments. A similar approach of using turtles as sentinel animals for the detection of contaminants is currently under investigation at the DOE Savannah River site by Dr. Whit Gibbons, working in collaboration with Dr. John Bickmam of Texas A\&M University (W. Gibbons and J. Bickman, Texas A\&M University, personal communication to L. Meyers-Schöne, Oak Ridge National Laboratory, 1986).

\subsubsection{Subtask 5a, Part 5: Critical Pathway Analysis--Waterfowl}

While there is generally a paucity of data on radionuclide uptake by waterfowl, several studies have been conducted by the DOE laboratories. Investigations have concentrated on the bioaccumulation of radionuclides through food webs and on the distribution of radioisotopes in avian tissues.

Researchers at Battelle Pacific Northwest Laboratories in Richland, Washington, have examined ${ }^{131} \mathrm{I}$ and ${ }^{32} \mathrm{P}$ levels in waterfow 1 on the Hanford waste ponds (Herde and Cline 1949, Herde et al. 1951, Kornberg and Swezea 1962). Cesium-137 concentrations were also measured in various compartments of the aquatic ecosystem (Cushing and Watson 1974). Of the radionuclides analyzed in waterfowl from the Hanford pond studies, ${ }^{131}$ I was found to exceed the chronic maximum permissible concentration set for humans (Herde et a1. 1951).

Bioaccumulation and elimination of gamma-emitting radionuclides have been studied in ducks at the Test Reactor Area radioactive leaching ponds at the Idaho National Engineering Laboratory site. The largest contributors to the internal radiation doses to waterfowl were ${ }^{137} \mathrm{Cs}$, 
${ }^{134} \mathrm{Cs}$, and ${ }^{60} \mathrm{Co}$ (Millard et al. 1978; Halford et al. 1978a, 1978b, 1981, 1982; Halford and Markham 1983). Data from these studies indicate that, although waterfowl can remove radionuclides from contaminated ponds, the levels were insufficient to cause radiation hazard to either birds or hunters consuming them.

Avian radionuclide studies at the DOE Savannah River Plant in South Carolina have focused on the dynamics of ${ }^{137} \mathrm{Cs}$. The body burdens of ${ }^{137} \mathrm{Cs}$ were determined in ducks, coots, and shorebirds (Brisbin et al. 1973, Domby et al. 1977, Fendley et al. 1977, Brisbin and Vargo 1982). Radiocesium levels in these birds did not indicate a hazard to human health from consumption (Brisbin et al. 1973).

WOL is located on the Mississippi Waterfowl Flyway, which is utilized for staging and overwintering areas. Hunting pressure is greatest in this flyway, with 5,561,700 ducks, coots, and geese harvested in 1982 (Carney et al. 1983). Krumholz (1954c) estimated that more than 6500 migratory waterfowl visited wOL during the 1952 migration. Twenty-one waterfowl species were recorded on WOL at that time, with mallards (Anas platyrhynchos) and wood ducks (Aix sponsa) being the most common inhabitants seen on the lake. According to the Tennessee Wildlife Resources Agency, the majority of waterfowl raised in Tennessee are wood ducks and Canada geese (Branta canadensis)

(R. Nichols, Tennessee Wildlife Resources Agency, personal communication to L. Meyers-Schöne, Oak Ridge National Laboratory, 1985).

Breeding ducks are relatively few on WOL. Field observations of waterfowl during mid-May to early June 1985 (L. Meyers-Schöne, Oak Ridge National Laboratory, unpublished data) revealed one goose nest; no duck nests were found. Very few pairs of ducks were seen during this period. Despite the relatively low numbers of breeding ducks, the number of migratory species visiting WOL annually, as well as the presence of a rapidly increasing Canada goose population, indicates a need to examine radionuclide accumulation in waterfowl from the ORNL environs.

A waterfow1 monitoring program will be designed and implemented to estimate probable doses of radionuclides to waterfowl, depending on feeding habits of different species as well as on time spent on the 
site. Radiation dose to resident species will be compared with that of transient migratory species. The monitoring program will involve capture of wild waterfowl and confinement of domesticated species on the site for whole-body counting of radioactivity. It will be implemented and carried out in cooperation with the Environmental and Health Protection Division at ORNL and the Tennessee Wildlife Resources Agency.

\subsubsection{Subtask 5b: Organics}

Data are sparse on the amounts and quantities of hazardous organic chemicals released to the terrestrial environment near ORNL. Likely candidates for waste organics, based on known activities at ORNL as well as common hazardous organics released to the environment elsewhere, include solvents, chlorinated pesticides, PCBs, and aromatic hydrocarbons associated with oils, grease, and coal pile runoff.

Measuring concentrations of organics in soil, plants, and animals in an exhaustive monitoring program would be exceedingly costly. The important question is not whether organic contaminants are present in the ORNL area, but rather whether these substances, which enter the ecosystem in air, soil, and water, are present in chemical forms and concentrations that enable them to move into the biota of the area. If these chemicals are present in plants and animals, the issue then becomes whether they are present at levels that will have an adverse ecological impact or, additionally, whether they could cause significant exposures to humans. Thus, the mobility and biological availability of toxic organic contaminants become the critical parameters for determining whether deleterious impacts on local wildlife, vegetation, or humans will occur.

of the different types of hazardous organics likely to occur in terrestrial systems at ORNL, the solvents can be omitted from a monitoring program directed at detecting effects on terrestrial biota. Solvents are likely to be readily dispersed in soil due to volatilization and leaching. Most solvents are readily metabolized by organisms; do not leave persistent, hazardous residues; and tend to become health problems only when inhaled in confined spaces. The possibility for contamination of groundwater could pose toxicological 
problems, but these are best detected by analysis of groundwater samples and not by residue analyses of terrestrial biota.

The presence and bioavailability of persistent, lipophilic organics, such as PCBs and chlorinated pesticides, can be monitored directly by residue analysis of animal fat samples. Because these persistent, lipophilic chemicals accumulate in fat, analysis of animals is preferred to analysis of soil or water to identify problems of PCB contamination. Biological monitoring provides an integration of animal exposure through time and over the home range of the sampled species (i.e., through space). In addition, residues have the potential for being detected in fatty tissue, due to bioaccumulation, even though they may not be present in detectable concentrations in soil, vegetation, and water.

More problematical is the evaluation of animal exposures to organics that are biologically active yet do not accumulate significantly. This is another situation in which exhaustive chemical analysis of all compartments becomes prohibitively costly. In addition, the mere documentation of the presence of a hazardous organic does not mean that it is biologically available to produce an effect. Such is the situation for PAHs, which can be toxic but usually do not accumulate in organisms. The approach to be used here is that of evaluating resident vertebrates for blood properties indicative of exposure to a common PAH typically present in environmental samples: for example, benzo[a]pyrene (BaP).

\subsubsection{Subtask 5b, Part 1: Blochemical Analyses of Vertebrates for Exposure to Hazardous Organics}

There is a potential health hazard associated with the transfer of organic compounds such as PAHs through terrestrial pathways to humans. Analyses of PAHs in soil and vegetation, coupled with determination of a representative $\mathrm{PAH}$ or its metabolites in small mammals living and feeding in a contaminated area, will be useful in establishing a quantitative analysis of $\mathrm{PAH}$ movement through terrestrial pathways. The PAHs are of concern because these compounds are often stable under 
environmental conditions and include many carcinogens and mutagens (e.g., BaP).

Because PAHs are rapidly metabolized, exposure of animals cannot be readily quantified by measuring body burdens. A highly sensitive technique for measuring BaP metabolites bound to hemoglobin has been developed (Shugart 1985) and $i$ - being tested for its applicability to monitoring programs to establish recent exposures.

The sampling program for organics will be carried out in conjunction with the monitoring of vertebrates for radionuclides. Blood will be taken from live animals to determine PAH exposure through inference based on BaP-adduct formation with hemoglobin. Livers from sacrificed animals will be used for determinations of DNA damage in cells.

By sampling and analyzing animals from a variety of sites representing a spectrum of contamination by both radionuclides and organics, a biochemical data base will be established by which the degree of exposure of vertebrates to radionuclides and hazardous organic chemicals can be inferred.

During the first stage of vertebrate trapping and analyses, chemical and radionuclide residue data will also be obtained for soil and vegetation. In later stages of the sampling program, soil and vegetation analyses will be required only as needed to identify the sources of contamination identified in the biochemical analyses of the animals.

\subsubsection{Subtask 5b, Part 2: Biopsy of Animal Fat for PCBs}

Fat samples will be taken from vertebrates sacrificed as part of the radionuclide and hazardous organics trapping activities. Fat samples will be analyzed for PCBs and chlorinated hydrocarbon pesticides. 


\subsection{RADIOECOLOGY OF WHITE OAK LAKE AND WHITE OAK CREEK (TASK 6)}

\subsubsection{Introduction}

WOL, which was impounded in 1943, serves as a final settling basin for radioactive effluents from ORNL before they are released over the dam at WCK 1.0. The radioactive effluents are continuously monitored as they flow over White Oak Dam. The gates at the dam are maintained at an elevation that allows water to be retained in the lake for a long period of time, thus permitting the radioactive decay of short-lived radionuclides and the settling of suspended solids. The size of the lake has varied from -2.4 to -16.2 ha, depending upon the elevation of the gate at the dam. In 1955 the lake was drained because it had come into equilibrium with WOC in terms of its ability to dilute and contain radioactive material. Since 1955, the lake has fluctuated in size from 2.4 to -10.1 ha for various reasons. To evaluate the integrity of the dam, the gates were lowered in 1979 to an elevation of $742 \mathrm{ft}$ (MSL), which resulted in a standing pond of 5.2 ha. Subsequently, a new and larger discharge structure was installed. Detailed descriptions of these activities can be found in Loar et al. (1981a), Oakes et al. (1982a), and Sherwood and Loar (1987).

\subsubsection{Radionuclides in White Oak Lake and White Oak Creek Watershed}

The first survey of radioactive releases into the wOC watershed was reported by Cheka and Morgan (1947). The radionuclide content in rOL sediment was estimated for 1950, 1951, and 1952 by Abee (1953). A summary of these results can be found in Oakes et al. (1982a).

The lake was drained in 1955, and Lee and Auerbach (1959) me asured the radiation field above the lake bed. The air dose, which ranged from 0 to $60 \mathrm{mR} / \mathrm{h}$ at $1 \mathrm{~m}$ above the surface of the lake bed, was related to the pattern of sediment deposition. During this time a number of terrestrial radipecological investigations were conducted on the revegetated lake bed (see review in Sect. 2.2.1).

In 1962 extensive core sampling was conducted in WOL to determine the vertical and lateral distribution of radionuclides in the lake bed (Lomenick and Gardiner 1965). Based on an analysis of 250 strategically 
located samples, the total estimated budget for the lake bed was $1952 \mathrm{Ci}$. More than half of the activity was located in the top $15-\mathrm{cm}$ layer of sediment. In $1962,{ }^{106} \mathrm{Ru}$ accounted for over 508 of the activity; ${ }^{137} \mathrm{Cs}$ and ${ }^{60} \mathrm{Co}$ were the second and third most-abundant radionuclides in the lake sediment. Most of the ${ }^{137} \mathrm{Cs}$ in the lake bed was associated with the lacustrine sediment, while the ${ }^{60} \mathrm{Co}$ was distributed throughout the lake ecosystem. Small quantities of ${ }^{90} \mathrm{Sr}$ were found throughout the lake, but in 1962 it accounted for less than 18 of the total activity in the sediment.

For the years after 1962, only limited data are available on radionuclide concentrations in WOL sediment, and these are from experimental studies. Samples were not taken for the purpose of determining an inventory of radionuclides in the sediments until 1979 , when 12 core samples were taken from the lower end of the lake (Oakes et a1. 1982a). Based on an estimated sediment volume for the lake and on the radionuclide concentrations in these core samples, it was estimated that the total activity in the lake was $644 \mathrm{Ci}$ : $591 \mathrm{Ci}{ }^{137} \mathrm{Cs}, 33 \mathrm{Ci}$ ${ }^{60} \mathrm{Co}$, and $20 \mathrm{Ci}{ }^{90} \mathrm{Sr}$. Other radionuclides are known to occur in wOL sediment, but they occur only in small quantities. The concentrations of transuranic elements in sediments were reported by Eyman and Irabalka (1980). Some core samples were collected in 1985 and analyzed for ${ }^{137} \mathrm{Cs}$ and ${ }^{60} \mathrm{Co}$. A summary of the radionuclides in wol sediment can be found in Oakes et al. (1982a) and Sherwood and Loar (1987).

Studies of the radioecology of wol are summarized briefly in Sect. 2.1.1. This summary includes information on radionuclide concentrations in fish and the effects of radiation on fish and other aquatic biota in WOL.

\subsubsection{Objectives}

The purpose of the radioecological monitoring of wOL is to determine whether potential exposure pathways to man exist that could result in radiation doses to individuals or populations that approach or exceed regulatory standards that may be applied to WOL. The identification of potential exposure pathways would be for current 
conditions, for possible accidental conditions, or for conditions resulting from future remedial actions.

The proposed radioecological monitoring program and field studies described in Task 6 will provide data for identifying potential pathways for human exposure for the following scenarios: (1) the lake is maintained under present conditions, and the exposure pathway is to individuals who consume fish, waterfowl, turtles, deer, and small game animals that live in WOL or its environs; (2) the public is allowed free access to the lake and its environs, and exposure pathways are from contaminated food and water taken directly from the lake sediments that could be used to grow agricultural products and from direct contact with the contaminated sediments; ( 3 ) the lake is maintained under present conditions with no additional input of radionuclides, but woC bypasses the lake; (4) the lake is drained and capped and a canal constructed around the lake; and (5) the lake is drained and excavated.

\subsubsection{Description of Subtasks}

\subsubsection{Subtask 6a: Radionuclide Screening}

Before an analysis of the potential for human or environmental exposure can be initiated, those contaminants on which such an analysis will be based must be identified (EPA 1985a). The purpose of this subtask is to conduct a screening exercise, based on available data, for the different scenarios to identify potential critical pathways for human exposure and to ideniify problem radionuclides. Available data will be used for the different parameter values in the screening exercise. The screening will identify potential problem areas that need additional monitoring and problem radionuclides that will need additional study. Based on these results, monitoring p'ograms will be developed and field studies designed to obtain the required data.

\subsubsection{Subtask 6b: Current Radioecological Status of White Oak Lake}

The present radioecological status of woL will be determined and compared with previous conditions: those in 1950, 1960, and 1970. The current concentration and quantity of radionuclides in fish, 
invertebrates, aquatic plants, and sediments will be established. If sufficient data are not presently available to establish the status of the lake ecosystem, monitoring programs and field studies will be carried out to obtain these data. Such baseline data are needed to establish the current radioecological status of the lake and its environs in order to assess the effectiveness of future remedial actions.

An inventory of the quantity, concentration, and distribution of radionuclides in the sediment of wOL will be established. The last inventory was taken in 1979, and it was a cursory one that included only three radionuclides: ${ }^{137} \mathrm{Cs},{ }^{60} \mathrm{Co}$, and ${ }^{90} \mathrm{Sr}$ (Oakes et al. 1982a). A more detailed inventory is needed that would include all radionuclides (fission products and transuranic elements) that have been released into the lake and are still detectable. The inventory would be based on a limited series of core samples that are strategically located based on data from previous sampling programs (see Sherwood and Loar 1987). Information on the volume and distribution of the radioactive sediments is needed, in addition to data on radionuclide concentrations, to provide input for cost-benefit analyses of possible remedial actions. Mass spectrometric analyses of selected subsets of sediment samples will also be performed to allow identification and quantification of actinides that are not separable by alpha spectrometry (e.g., ${ }^{233,234} \mathrm{U}$ ).

The size of the fish populations in wOL will be established (Sect. 3.4.2), and the concentrations of the major radionuclides in bluegill, carp, shad, and largemouth bass will be determined. Fish will be collected and analyzed to determine the average concentration of the principal radionuclides. The total biomass and concertration of radionuclides in the macrophyte and benthic invertebrate communities will also be established. In addition, the concentration of radionuclides in fish from wOC above the lake will be determined. This effort will be coordinated with the sampling for nonradiological contaminants described in Task 2 (Sect. 3.2.1); wherever possible, the same fish will be used for both types of analyses. 


\subsubsection{Subtask 6c: Remobilization of Radionuclides from Sediments}

The environmental factors that influence the remobilization of radionuclides and other contaminants from the sediments of WOL will be investigated in Subtask $6 \mathrm{c}$. Sediments are often referred to as sinks for many of the contaminants that enter aquatic ecosystems; however, they may serve as a secondary, or under certain conditions, a primary source of contaminants to aquatic food chains. After ar extended period of continuous discharge of radioactive effluents, concentrations of radionuclides may be several orders of magnitude higher in sediments than in the aqueous phase of freshwater systems. In WOL, the contribution of remobilized radionuclides to aquatic food chains is unknown. Also, the contribution of radionuclides from the sediments, either in the form of suspended matter or in the dissolved form, to the quantity of radioactivity passing over the dam is unknown. In scenarios 1,2 , or 3 (Sect. 3.6.1), in which the lake remains under present conditions or the input of radionuclides to wOL is discontinued but a lake environment is maintained, it will be necessary to know (1) the potential for radionuclides in the sediments to accumulate in aquatic food chains and (2) the potential for release of radioactivity over the dam from sediment remobilization.

For effective and efficient remedial action, information is needed on the biological, chemical, and physical factors that affect the remobilization of radionuclides from the sediments of WOL. Studies will be designed to determine the contribution of remobilized radionuclides from sediment to (1) aquatic food chains in wOL and (2) the quantity of radionuclides released over the dam. Field and laboratory studies will also be designed to determine the environmental factors that influence the remobilization of radionuclides from wOL sediments and their subsequent accumulation in aquatic food chains. 


\subsection{CONTAMINANT TRANSPORT, DISTRIBUTION, AND FATE IN THE WHITE OAK CREEK EMBAYMENT-CLINCH RIVER-WATTS BAR RESERVOIR SYSTEM (TASK 7)}

\subsubsection{Introduction}

Contaminants from ORNL operations are released from wOL and transported downstream into WOC embayment, into the Clinch River at CRK 33.5 ( $3.7 \mathrm{~km}$ below Melton Hill Dam), and ultimately into Watts Bar Reservoir. In this task, coordinated ecological and biogeochemical studies will be conducted to determine the transport, distribution, and ecological fate of contaminants introduced into the WOC embayment-Clinch River-Watts Bar Reservoir system as a result of waste disposal activities at ORNL. These studies will be closely coordinated with and complementary to other biological monitoring tasks included in BMAP. Task 7 will focus on (1) assessing through scoping efforts the extent of contamination of the aquatic environment downstream of WOL;

(2) identifying and quantifying the physical, chemical, and biological processes governing the transport, distribution, and ecological fate of contaminants in the embayment-river-reservoir system; and

(3) establishing quantitative baseline data on contaminant distribution in the river-reservoir sediments and on the contaminant burden of benthic organisms that will permit a direct assessment of the effectiveness of remedial actions at ORNL.

\subsubsection{Background}

Readily soluble contaminants (e.g., ${ }^{3} \mathrm{H},{ }^{90} \mathrm{Sr}$, and some metals) released from ORNL tend to remain in solution, are rapidly diluted in the Clinch River and Watts Bar Reservoir, and, for the most part, flush through the system (Nelson 1962, Cowser et al. 1966). However, these dissolved contaminants are readily available for biological uptake, and following large releases, they can pose a threat to public water supplies. For such soluble materials, the extent of the contamination of downstream systems depends primarily on their rates of dilution, the residence time of water in various portions of the system, and the degree of contaminant retention by biota. 
In contrast, many radionuclides $\left({ }^{60} \mathrm{Co},{ }^{137} \mathrm{Cs},{ }^{239} \mathrm{Pu},{ }^{241} \mathrm{Am},{ }^{244} \mathrm{Cm}\right)$, synthetic organic compounds (PCBs, PAHs), and heavy metals ( $\mathrm{Pb}, \mathrm{Hg}, \mathrm{Zn}$, $\mathrm{Cd}, \mathrm{Cu}$ ) are particle reactive and rapidly sorb to inorganic (silts, clays) and organic (planktcnic algae and bacteria, detritus) suspended particles. Depending on the concentrations of suspended particles available for contaminant sorption (as affected by biological particle production), the contaminant sorption kinetics (as influenced by complexation with natural dissolved organic matter), and the settling rate of particles from the water column, these particle-reactive contaminants are removed from the water column by particle settling and accumulate in bo:tom sediments.

Sedimentation dors ot necessarily represent a permanent sink for particle-associated contaminants, however. Particularly in river-reservoir systems, recently deposited material may remain physically, chemically, and biologically dynamic for some time (Golcman and Kimmel 1978). Sediment resuspension can raintroduce particle-associated contaminants to the water column, where they again berome available to filter-feeding organisms. Resuspension and redeposition also result in the transport of fine sediment particles downstream and $f$ :om shallower to deeper portions of basins (e.g., Davis 1968, 1973; Kimmel 1978) and thereby can influence the relative exposure and availability of particle-associated contaminants to various components of the aquatic biota. Contaminants can also be released from sediments by biological actions or by changes in the chemical environment. As organic matter decomposes, associated contaminants may be reduced or complexed into more-soluble forms and released from rarticles. With changes in environmental Eh-pH conditions, some contaminants (such as ${ }^{60} \mathrm{Co}$ ) may be released from sediments in association with the redox cycling of iron and manganese (Cerling ard Turner 1982). Ultimately, the dynamics of the particle-associated contaminant pool control (1) the extent of contaminant bioavailability, food web contamination, and potential pathways to man and (2) the recovery rate of aquatic and biotic pools in contaminated environments fol ${ }^{\prime}$ ving remedial actions to reduce contaminant lcadings. 
Previous surveys of radionuclide concentrations in $\mathrm{Clinch}$ River sediments indicated that only 208 of the ${ }^{137} \mathrm{Cs}$ (and less than 28 of the total radioactivity) discharged from wol prior to 1962 could be accounted for in the Clinch River (Parker et al. 1966, Pickering et al. 1966, Carrigan 1969, Oakes et al. 1982b). One of the major conclusions of these earlier studies was that contaminants released from ORNL did not accumulate in the sediments or biota of the Clinch River, but were transported downstream into Watts Bar and Chickamauga reservoirs. Because these earlier studies were restricted primarily to the Clinch River, there has been no attempt to quantify the extent of contaminant accumulation within the downstream Tennessee River Reservoir system.

Reservoirs are known to be efficient traps for river-borne particles and particle-associated contaminants (Dendy et al. 1973, Kimmel and Groeger 1986). Recent analysis of sediment cores obtained from Watts Bar and Chickamauga reservoirs has shown that (1) the vertical profile of ${ }^{137} \mathrm{Cs}$ in the reservoir sediments correlates well with the historical record of ${ }^{137} \mathrm{Cs}$ releases from ORNL (Fig. 9) and (2) the sediments of Watts Bar Reservoir likely contain a large fraction of the ${ }^{137} \mathrm{Cs}$ and other particle-associated contaminants released from ORNL and the other Oak Ridge facilities during the past 40 years (Turner et al. 1985). On one hand, the accumulation of ORNL-derived contaminants in the sediments of Watts Bar Reservoir represents a long-term environmental problem; on the other hand, the reservoir sediments constitute a historical record of contaminant releases that, when properly documented, will provide a quantitative baseline for determining the effectiveness of the remedial action programs now being initiated at ORNL.

\subsubsection{Objectives and Approach}

The extensive survey of the aquatic ecology of the wOC watershed and the Clinch River below Melton Hill Dam conducted by Loar et al. (1981a) provides an excellent information base for assessing the effects of ORNL contaminant releases and remedial actions on the structure of the biotic communities occurring in the WOC embayment and 

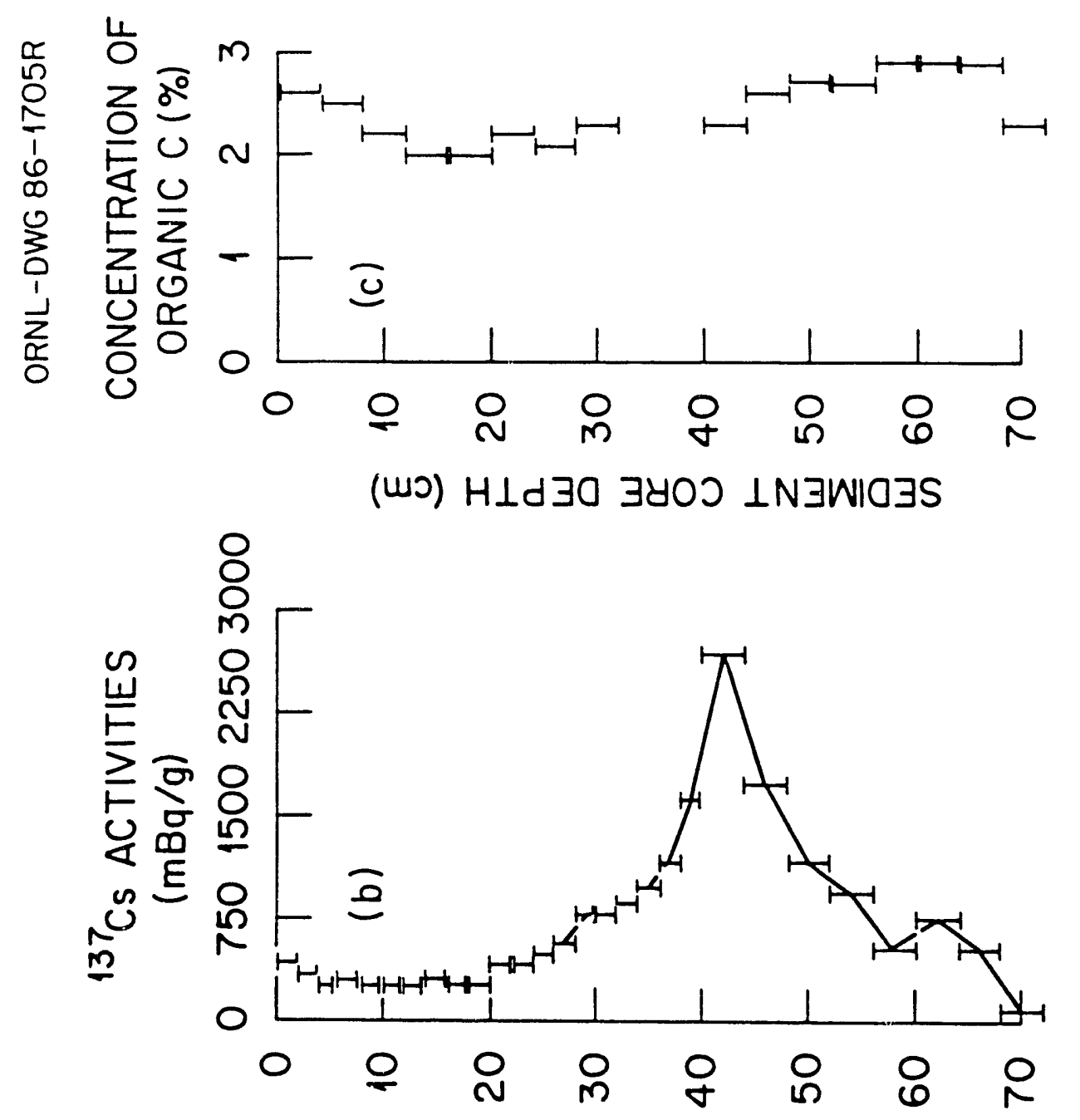

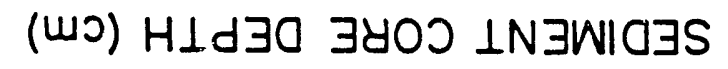
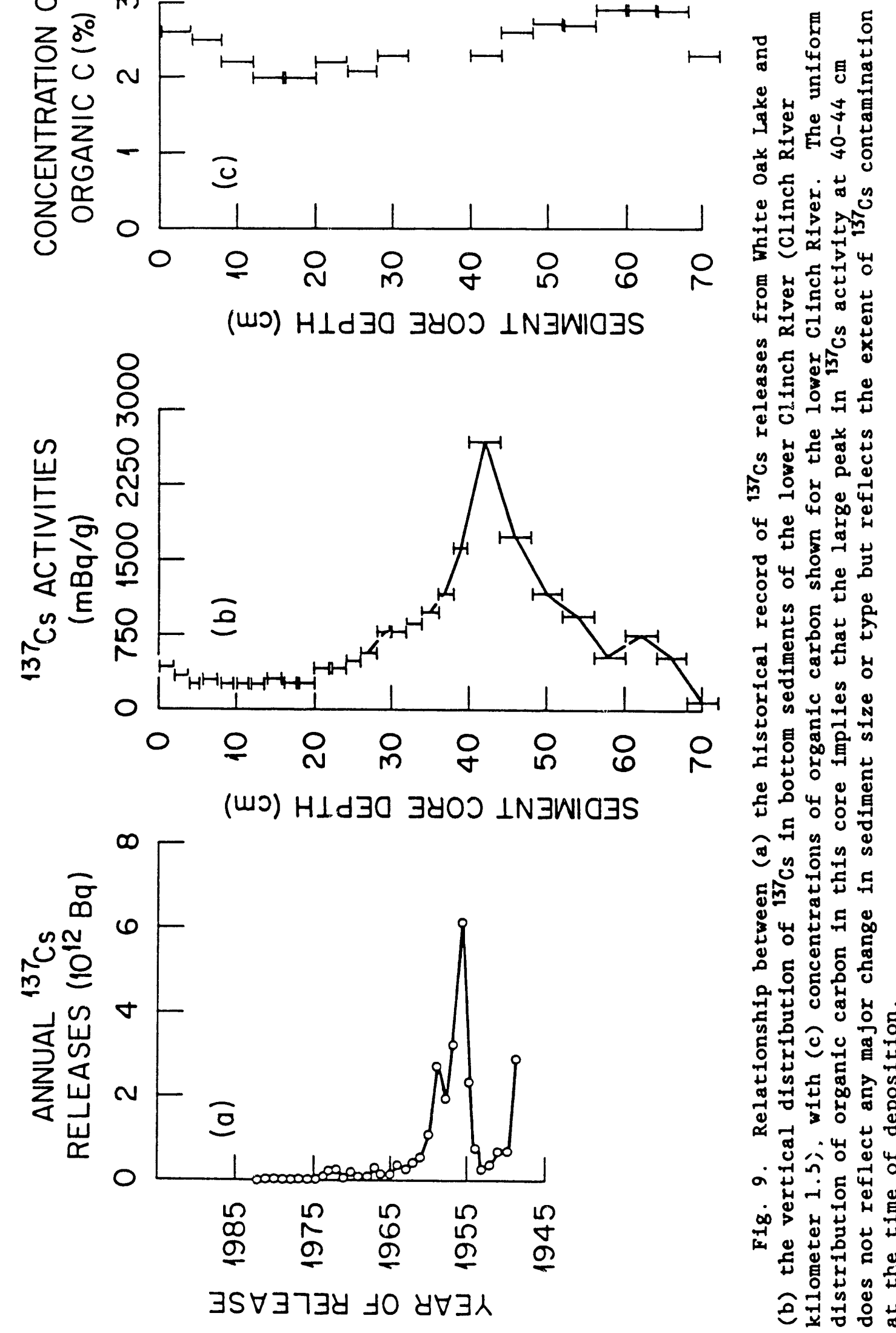

等

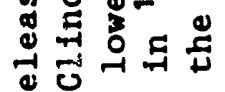

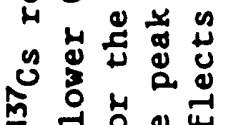

出

山ै

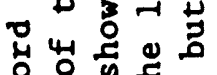

号的

古艺

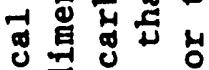

岀过 $0 \begin{gathered}0 \\ 0\end{gathered}$

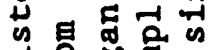

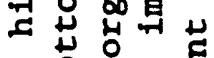

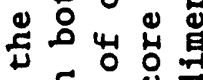

政

क्ष

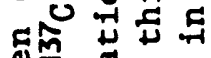

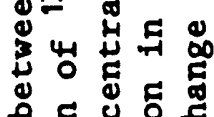

동ㅇํㅇ 융

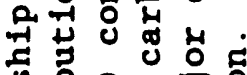

ติ

少

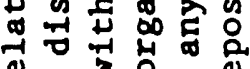

व 1000

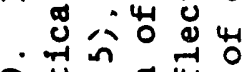

a㔖?

๑

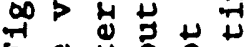

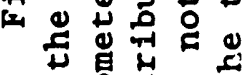

年

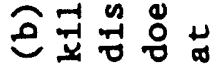


in the Clinch River upstream and downstream from the mouth of WOC. The existence of this baseline of ecological data allows efforts in this task to focus on (1) documentation of the extent of the contamination of the embayment-river-reservoir system; (2) quantification of the physical, biological, and geochemical processes controlling contaminant transport, distribution, bioavailability, and fate; and (3) prediction and assessment of the effectiveness of ORNL remedial action measures to reduce contaminant releases.

More specifically, the primary objectives of Task 7 are

1. to review, integrate, and synthesize previous information and data on the ecological fate of radionuclides and other contaminants discharged from WOL to the WOC embayment-Clinch River-Watts Bar Reservoir system;

2. to determine the extent of and the spatial distribution of contaminant accumulation in the sediments and in selected biota of the embayment-river-reservoir system;

3. to identify and quantify the hydrodynamic, biological, and geochemical factors that determine the transport, distribution, and accumulation of ORNL-derived contaminants in the WOC embayment, the Clinch River, and Watts Bar Reservoir;

4. to predict the effect of ORNL remedial actions by using simulation models that incorporate the hydrodynamic, biological, and geochemical factors to be investigated in pursuing objective 3 ; and

5. to establish a baseline of data on contaminant distribution in the river-reservoir sediments and on the contaminant burden of river-reservoir organisms that will permit a direct assessment of the effectiveness of remedial actions at ORNL.

To accomplish these objectives, four subtasks (Fig. 10) are proposed, which include an interdisciplinary combination of simulation modeling, field measurements and sampling, and laboratory experimentation and analysis.

A key component of this investigative approach is the use of natural and man-made radionuclides as biogeochemical tracers of 


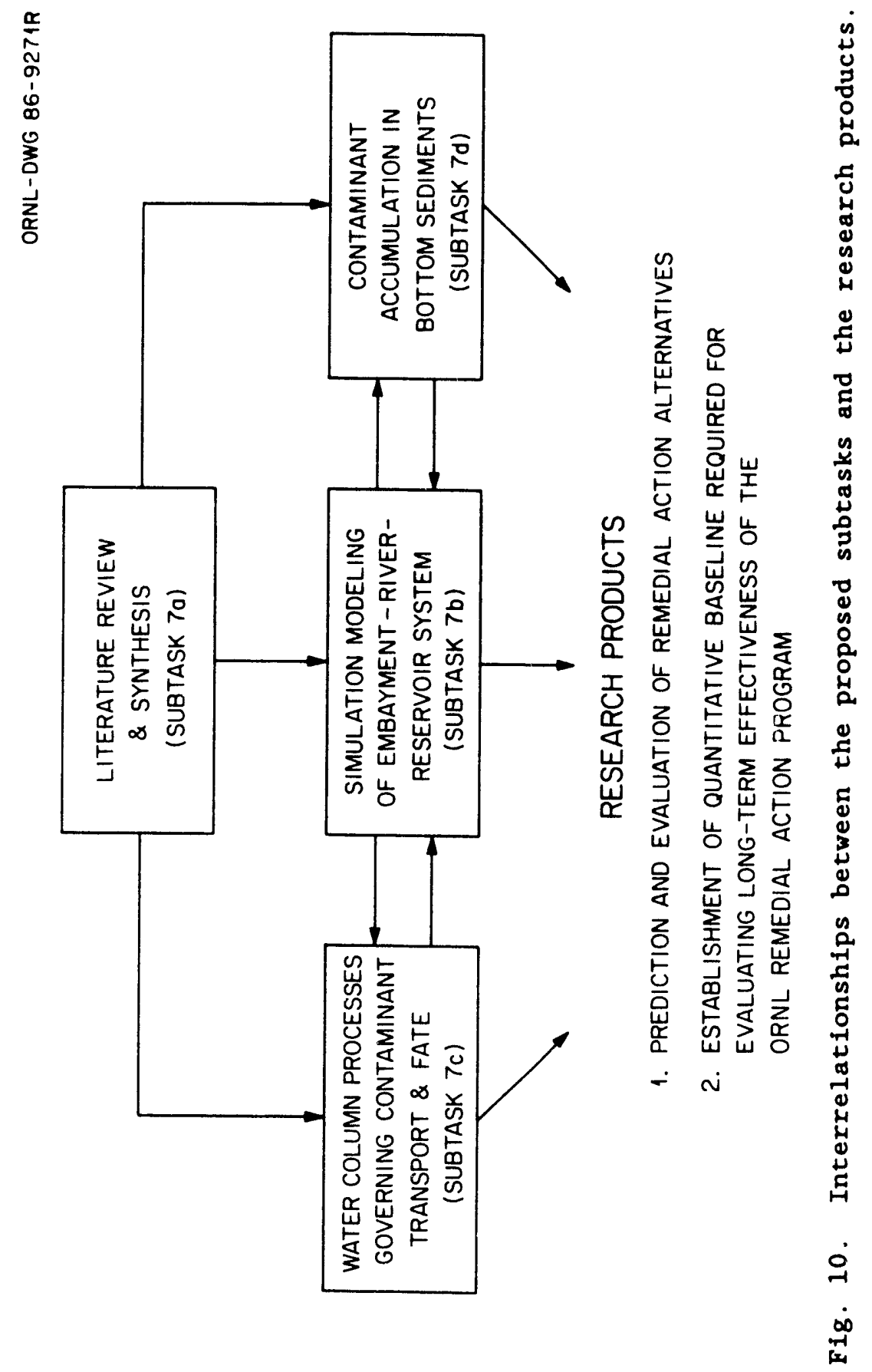


contaminants in the environment. In addition to providing site-specific data on the distributions and ecological fate of a variety of radionuclides $\left({ }^{137} \mathrm{Cs},{ }^{90} \mathrm{Sr},{ }^{60} \mathrm{Co},{ }^{241} \mathrm{Am},{ }^{238} \mathrm{Pu}\right.$, and $\left.{ }^{244} \mathrm{Cm}\right)$ released from ORNL into the embayment-river-reservoir system, ${ }^{137} \mathrm{Cs}$ and naturally occurring 'Be will be used as surrogate tracers of other particle-associated contaminants (such as PCBs, PAHs, and heavy metals). Cesium-137 and 'Be can be readily measured in the laboratory by nondestructive, high-resolution gamma spectrometry. Thus, the distributions of these two nuclides will be used to (1) specifically identify areas of contaminant accumulation and (2) select sediment cores that provide an intact historical record of contaminant deposition. This "screening" of samples by gamma spectrometry will provide a cost-effective way to select areas, samples, and organisms for other more expensive and time-consuming chemical analyses.

\subsubsection{Description of Subtasks}

\subsubsection{Subtask 7a: Literature Review and Synthesis}

The available information on the fate of radionuclides and other contaminants discharged from WOL to the embayment-river-reservoir system will be reviewed, integrated, and synthesized. This review will include the extensive investigations conducted in the early 1960 s by P. H. Carrigan, K. E. Cowser, V. I. Knopf, R. J. Morton, D. J. Nelson, F. L. Parker, R. J. Pickering, E. G. Struxness, and others on radionuclide transport, biological uptake, and accumulation. Additionally, the information reported more recently by Loar et a1. (1981a), Oakes et al. (1982b), Turner et al. (1985), and Ashwood et al. (1986) will be reviewed. The synthesis of this extensive information base is critical for (1) characterizing the aquatic environment adjacent to and downstream from the ORNL facilities, (2) planning the sampling program in an efficient and effective manner, and (3) adequately assessing regulatory compliance. 


\subsubsection{Subtask 7b: Simulation Modeling of the Embayment-River- Reservolr System}

The transport, distribution, bioavailability, and ecological fate of contaminants discharged from wOL (or from a discharge canal, if WOL is bypassed) will be strongly influenced by the hydrodynamic regime and by suspended-particle dynamics. The embayment-river-reservoir system is highly dynamic, as hydropower and flood-control operations at the Melton Hill and Watts Bar dams result in both daily and seasonal variations in flow velocity and direction, water column mixing, suspended-particle transport, water residence times, and water levels. Similarly, the transport, bioavailability, and fate of contaminants that become associated with suspended particles will be affected by biological particle production, complexation of contaminants with dissolved organic matter in the water column, contaminant sorption kinetics, particle sedimentation, resuspension, and redistribution.

Linked simulation models of the embayment, river, and reservoir (Fig. 11) will be used throughout the investigation. Initially, simple, two-dimensional flow models will be constructed, based on the morphology of embayment, river, and reservoir portions of the system and using WOL and Melton Hill Dam discharge data as input variables. These simple models will be employed to derive initial estimates of the influence of the hydrodynamic regime on the transport, bioavailability, contaminant-particle interactions, particle deposition, and extent of retention of contaminants in various portions of the system.

Information derived from field measurements of water column dynamics, suspended-particle concentrations, biological particle production, sorption kinetics and water column removal rates for ${ }^{7} \mathrm{Be}$, sediment deposition rates, and contaminant concentrations in sediments and biota (see descriptions of Subtasks $7 \mathrm{c}$ and $7 \mathrm{~d}$ in Sects. 3.7.4.3 and 3.7.4.4) will be incorporated into expanded versions of these flow models to permit integration of data on physical, chemical, and biological processes controlling contaminant transport and distribution in the embayment-river-reservoir system. Additionally, both simple and morecomplex versions of these simulation models will be used to predict and evaluate the relative effectiveness of remedial action alternatives. 


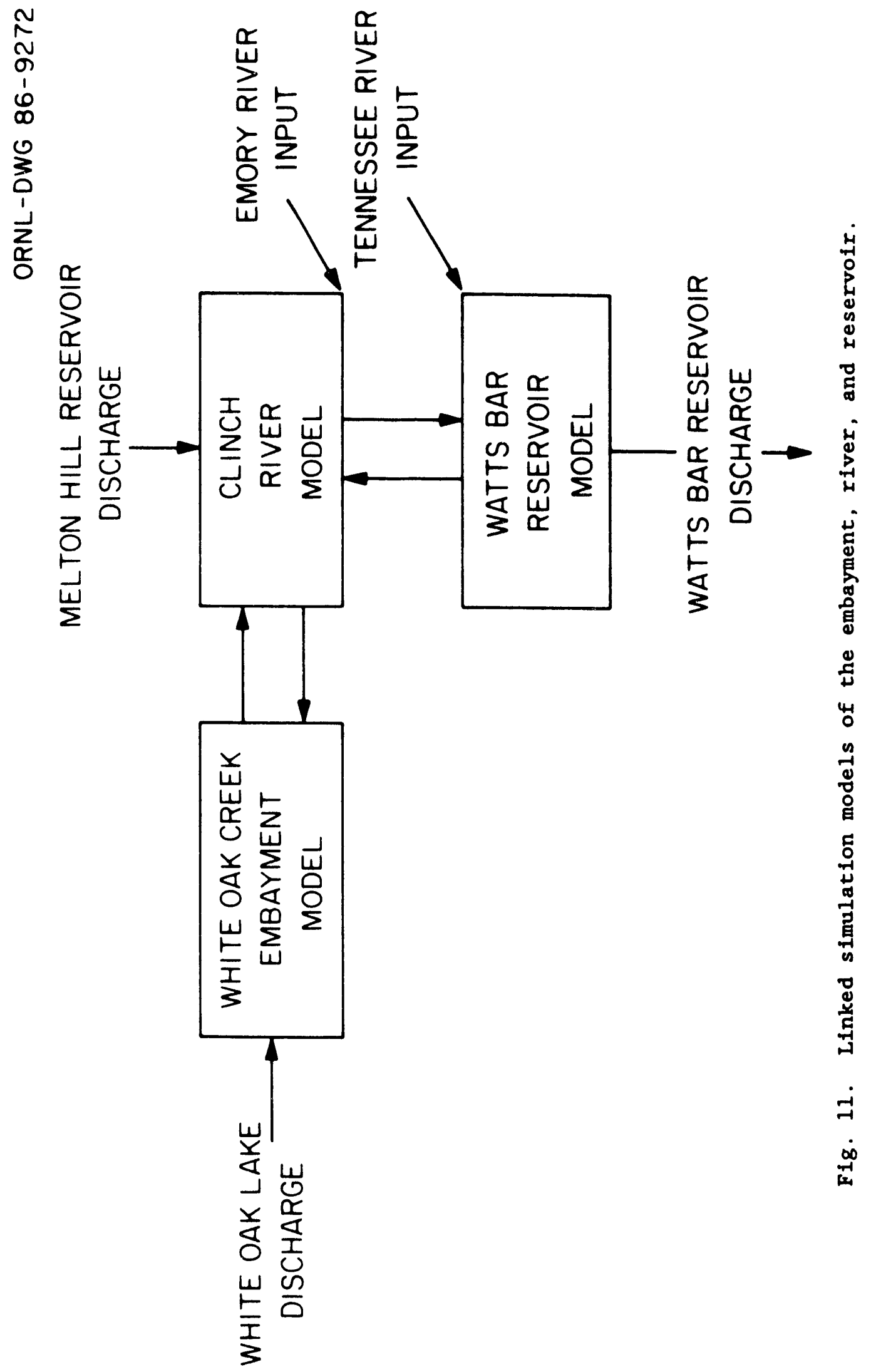




\subsubsection{Subtask 7c: Water Column Processes Governing Contaminant Transport and Fate}

Subtask 7c, Part 1: Exposure of blota to soluble contaminants Strontium-90 will be used as an analogue of a contaminant that remains in solution when discharged into the embayment-river-reservoir system. Bivalve molluscs bioconcentrate ${ }^{90} \mathrm{Sr}$ (by factors of $10^{3}$ to $10^{4}$ ) in their shells (Nelson 1962). Measurements of ${ }^{90} \mathrm{Sr}$ concentrations in whole clam shells will be used as a biological indicator of long-term exposure of the aquatic biota to such soluble contaminants. Size classes of shells of the small, short-1ived (4-6 years) Asiatic clam (Corbicula fluminea) will be selected to minimize the duration of contaminant exposure represented by our measurements. Corbicula fluminea is an exotic clam that is abundant and ubiquitous throughout the embayment-river-reservoir system (Mattice and Wright 1985), and, because of its sedentary nature, ${ }^{90} \mathrm{Sr}$ concentrations in Corbicula shells obtained from various locations throughout the embayment-river-reservoir system should reflect relative levels of ${ }^{90} \mathrm{Sr}$ exposure. Nelson (1962) reported that ${ }^{90} \mathrm{Sr}$ levels in clam shells in the Tennessee River corresponded to exposure levels estimated by a simple dilution model.

A preliminary, limited set of Corbicula samples will be collected and analyzed along the longitudinal axis of the embayment-riverreservoir system to evaluate the utility of this method as an indicator of ${ }^{90} \mathrm{Sr}$ releases from ORNL. If ${ }^{90} \mathrm{Sr}$ concentrations in clam shells correspond to those expected from dilution, additional samples will be collected to better document the ${ }^{90} \mathrm{Sr}$ distribution and to conduct analyses of soft clam tissue for other contaminants (e.g., PCBs, PAHs).

Large-volume sediment cores will also be collected (with a box corer) at selected sampling stations, and clam shells taken from different vertical sections of the core will be analyzed to establish a historical record of ${ }^{90} \mathrm{Sr}$ exposure. Sediment subsamples will be analyzed for ${ }^{210} \mathrm{~Pb}$ and ${ }^{137} \mathrm{Cs}$ to provide a sediment chronology. Such a vertical profile of ${ }^{90} \mathrm{Sr}$ exposure levels will provide a quantifiable benchmark for future assessments of the effectiveness of remedial actions at ORNL. 
Subtask 7c, Part 2: Suspended-particle dynamics, sorption kinetics, and contaminant removal rates

The hydrodynamics and limnology of the WOC embayment are strongly influenced by hydropower operations at the Melton Hill Dam (Loar et a1. 1981a) located just $3.7 \mathrm{~km}$ upstream. Because the Norris and Melton Hill reservoirs (located on the upper $\mathrm{Clinch}$ River) function as efficient traps for suspended particles, the water discharged from the Melton Hill Dam usually contains low concentrations of suspended particles. Therefore, in the Clinch River and the Watts Bar Reservoir, the photosynthetic production of organic matter by planktonic algae will be an important source of suspended particles available for contaminant sorption and of dissolved organic compounds capable of complexing radionuclides and other contaminants. Recent research indicates that phytoplankton productivity plays an important role in contaminant removal by particle settling (Talbot and Andren 1984).

Recent limnological studies of the Norris-Melton Hill-Watts Bar reservoir series (Elser and Kimmel 1985) have shown that patterns of phytoplankton production are controlled by the combination of nutrient availability, light availability as influenced by water column mixing, and the relationship of algal growth rates and water residence time in various parts of the regulated river system. Because of the factors affecting phytoplankton particle production and the rapid downstream transport of water through the river segment between Melton Hill Dam and upper Watts Bar Reservoir, it is hypothesized that most contaminant sorption, biological uptake of contaminants by planktonic biota, and removal of particle-associated contaminants from the water column by settling will occur primarily in three areas: (1) WOC embayment, (2) marginal embayments downstream from the mouth of WOC, and (3) the upper portion of Watts Bar Reservoir.

Field measurements will be made to quantify the flow regime, thermal stratification and relative water column stability, suspendedparticle concentrations, and phytoplankton biomass and distribution at stations in WOC embayment, in the Clinch River, and in Watts Bar Reservoir. Selection of sampling stations will be guided by the results of the initial flow-modeling efforts. Measurements will be 
conducted on a seasonal basis and during a variety of flow conditions (e.g., during low-flow vs peaking-power releases from the Melton Hill Dam) in order to document a range of flow velocities, mixing regimes, levels of biological activity, particle production rates, and suspendedparticle concentrations.

In conjunction with quantification of these environmental variables, aqueous-particulate phase partitioning of ${ }^{137} \mathrm{Cs},{ }^{60} \mathrm{Co},{ }^{7} \mathrm{Be}$, ${ }^{210} \mathrm{~Pb}$, and ${ }^{90} \mathrm{Sr}$ will be determined at sampling stations in wOC embayment, in marginal embayments downstream from the mouth of WOC, and along the longitudinal axis of the river-reservoir system. In accordance with the previously stated hypothesis concerning contaminants, a shift would be expected from dissolved to particulate partitioning of radionuclides in the embayments and in the reservoir in correspondence with increased phytoplarkton production and suspended-particle concentrations.

Because of relatively low concentrations of radionuclides in water columns in most of the Clinch River-Watts Bar Reservoir system, continuous-flow centrifugation will be used to remove the suspended particulate matter from large-volume (1000-L) water samples.

Aqueous-phase radionuclides will be concentrated by coprecipitation or sorption by ammonium molybdophosphate (for ${ }^{137} \mathrm{Cs}$ ), by $\mathrm{Fe}(\mathrm{OH})_{3}$ (for ${ }^{60} \mathrm{Co}$, ${ }^{7} \mathrm{Be}$, and ${ }^{210} \mathrm{~Pb}$ ), and by $\mathrm{BaSO}_{4}$ (for ${ }^{90} \mathrm{Sr}$ ). Particulate- and aqueous-phase samples will be analyzed in our laboratory for ${ }^{137} \mathrm{Cs},{ }^{60} \mathrm{Co},{ }^{7} \mathrm{Be}$, and ${ }^{210} \mathrm{~Pb}$ by gamma spectrometry through the use of low-background, high-resolution, germanium detectors equipped with a Nuclear Data Model 6700 multichannel microprocessor system. Strontium-90 will be analyzed by low-background, gas-proportional beta-counting. Selected samples will also be analyzed for uranium isotopes, plutonium isotopes, ${ }^{99} \mathrm{Tc}$, PCBs, PAHs, and trace metals.

Complexation of radionuclides and other contaminants by dissolved organic matter (DOM) also influences aqueous-particulate partitioning and, thereby, can affect the bioavailability and transport of contaminants (Means et al. 1978; Olsen et al. 1983; McCarthy and Jimenez 1985a, 1985b; McCarthy et al. 1985). DOM in natural waters derives primarily from the decomposition of terrestrial vegetation and from extracellular products of phytoplankton photosynthesis and usually 
constitutes about 908 of the total organic matter pool in the water column. In controlled laboratory experiments, the effect of various DOM concentrations on (1) the sorption of ${ }^{137} \mathrm{Cs},{ }^{99} \mathrm{Sr},{ }^{60} \mathrm{Co}$, and radiolabeled PCBs and PAHs to suspended particles and (2) the uptake of these contaminants by aquatic organisms (e.g., Dophnia, Corbicula, chironomids, bluegill sunfish) representative of the embayment-river-reservoir system will be determined. Experimental techniques and procedures for this work have been developed and are now being applied in biological monitoring studies of East Fork Poplar Creek (see Loar et al. 1989 for more detail), but have not previously been applied to examine radionuclide partitioning and biological uptake. Experimental results will be incorporated into our contaminant transport and fate model as an essential link between field measurements of DOM and suspended-particle concentrations and estimates of in situ contaminant sorption kinetics, removal rates, and bioaccumulation.

Sorption to su pended particles and removal fron the water column by particle settling are perhaps the most important processes affecting the transport, distribution, and biological availability of particle-reactive contaminants in aquatic ecosystems. Naturally occurring ${ }^{7} \mathrm{Be}$ will be used as a geochemical tracer to quantify the removal behavior of particle-associated contaminants in various portions of the embayment-river-reservoir system. Beryllium-7 (53.3-d half-life) is produced by cosmic-ray spallation of nitrogen and oxygen in the atmosphere. It is deposited on the earth's surface as a dissolved constituent of rainwater and is rapidly sorbed by aboveground vegetation or soils in terrestrial systems and by suspended particulate matter in aquatic systems. Beryllium-7 has a particle-to-water distribution coefficient $\left(4 \times 10^{4}\right)$ that is typical of other particle-reactive contaminants such as ${ }^{137} \mathrm{Cs},{ }^{60} \mathrm{Co},{ }^{241} \mathrm{Am},{ }^{244} \mathrm{Cm},{ }^{239} \mathrm{Pu}, \mathrm{PCBs}, \mathrm{PAHs}, \mathrm{Pb}, \mathrm{Hg}$, $\mathrm{Zn}, \mathrm{Cd}$, and $\mathrm{Cu}$. Because of its continuous production in the atmosphere, its measurable flux to the earth's surface, its short half-life, and its particle-reactive nature, 'Be represents a powerful new tool for examining the short-term biogeochemical dynamics of particle-reactive materials in aquatic ecosystems (01sen et al. 1986). 
The sorption kinetics and the water column residence time of ${ }^{7} \mathrm{Be}$ will be quantified in various portions of the embayment-river-reservoir system by (1) collecting time series of large-volume water samples following major inputs ố ${ }^{7} \mathrm{Be}$ by natural precipitation events; (2) measuring the distribution of 'Be in dissolved and particulate phases by continuous-flow centrifugation and high-resolution gamma spectrometry, as described previously; and (3) calculating the rates at which the dissolved ${ }^{7} \mathrm{Be}$ input is sorbed to suspended particulate matter and then removed from the water column by particle settling. Because many of the contaminants released into the embayment-river-reservoir system from ORNL are particle reactive, quantitative data on the sorption kinetics and removal rates of ${ }^{7}$ Be will be directly applicable for predicting the transport, water column residence time, and biological availability of these contaminants.

Results derived from this subtask will be integrated into the contaminant transport and fate model (Subtask $7 \mathrm{~b}$ ) for application in (1) predicting the consequences of remedial action alternatives and (2) assessing the long-term effectiveness of the ORNL Remedial Action Program.

\subsubsection{Subtask 7d: Contaminant Accumulation in Bottom Sediments}

The vertical distribution of ${ }^{137} \mathrm{Cs}$ in sediment cores collected from long-term contaminant accumulation sites in upper Watts Bar Reservoir is strongly correlated with the historical record of ${ }^{137} \mathrm{Cs}$ discharges from WOL (Fig. 9). The discharge histories of other particle-reactive contaminants released from ORNL are also recorded in the sediments of undisturbed long-term accumulation sites; these histories can be documented with other sediment core data to be obtained in this subtask.

The distribution of ${ }^{137} \mathrm{Cs}$, which is strongly particle reactive (Lomenick and Tamura 1965), can be used as a cost-effective tracer (1) to identify and distinguish areas of contaminant-particle accumulation and areas of erosion (no net accumulation) in the embayment-river-reservoir system and (2) to screen sediment samples prior to other, more costly, contaminant analyses. As part of an initial scoping effort for this subtask, sediment cores will be 
collected from selected sites throughout the river-reservoir system (including wOC embayment and marginal embayments downstream) with an inexpensive vibrocore system that has been used routinely to sample river, reservoir, and estuary sediments in other ORNL projects. Results from the flow models will guide the initial selection of sediment coring stations. Cores will be sectioned in 2 - to $4-\mathrm{cm}$ intervals, sealed in $90-\mathrm{cm}^{3}$ aluminum cans, and the ${ }^{137} \mathrm{Cs}$ activity quantified for each core segment by high-resolution gamma spectrometry in the laboratory. Lead-210 activity ir. these samples can also be determined to independently establish an accurate sediment chronology.

In conjunction with the sediment coring, dredge samples of benthic organisms will be collected at each sediment-coring site to permit an assessment of contaminant bioaccumulation. Significantly higher contaminant body burdens can be expected in benthic organisms collected from areas of high contaminant accumulation than in benthos from relatively uncontaminated sites. These analyses, in combination with bioaccumulation data on organisms from MB, WOC, and WOL (Tasks 2 and 6 , as described in Sects. 3.2 and 3.6, respectively), will contribute to a comprehensive record of the extent of the spatial distribution of contamination of the benthic biota downstream from ORNL discharge points.

By using ${ }^{137} \mathrm{Cs}$ distributions to select sediment cores and samples of benthic organisms for additional contaminant analyses, an initial inventory of contaminant accumulation in the sediments and in benthic organisms can be conducted in a cost-effective and efficient manner. This initial sampling effort will provide a scoping of the spatial extent of river-reservoir radiological contamination and will permit identification of specific areas in which additional sampling and detailed chemical analyses are required. Ultimately, both the historical sediment record (the vertical distribution of contaminants) and data on the spatial distribution of the contamination will be used to improve contaminant budgets for the river-reservoir system and to quantify the extent to which operations at the Oak Ridge facilities have contaminated the downstream aquatic environment. These results will 
establish a quantitative scientific baseline of information required for evaluating the long-term effectiveness of the Remedial Action Program.

\subsubsection{Summary}

Task 7 consists of an interdisciplinary combination of simulation modeling, field measurements and sampling of the water column and sediments, and laboratory experimentation and analyses to determine the transport, distribution, and ecological fate of contaminants introduced into the WOC-Clinch River-Watts Bar Reservoir system as a result of waste disposal activities at ORNL. The distributions of selected radionuclides will be measured in the water and in suspended particulate matter, sediments, and biota of the embayment-river-reservoir system. These radionuclide measurements will be performed in the laboratory by nondestructive, high-resolution gamma spectrometry and will provide

1. site-specific data on the distribution, bioaccumulation, and ecological fate of a vaxiety of radioactive contaminants discharged from ORNL;

2. a means of estimating water-particulate phase partitioning, sorption kinetics, water colimn residence times, and areas of accumulation for other particle-reactive contaminants; and

3. a cost-effective basis for selecting areas, samples, and organisms for more-costly chemical analysis for PCBs, PAHs, and heavy metals.

Linked flow models of the embayment, river, and reservoir will be developed to guide the initial sampling design and to permit preliminary predictions of contaminant transport and fate. The models will be continuously refined by incorporating field and laboratory results and will be used to ( 1 ) examine the interrelationships between variable physical, chemical, and biological conditions and contaminant transport, bioavailability, and fate; (2) provide guidance for additional sampling and analysis; and (3) predict the effects of alternative remedial action measures. In an initiai scoping effort, sediment cores and bentric organisms will be collected and analyzed to better document the historical record of contaminant-particle accumulation and to determine. 
the spatial extent of the contamination problem in the embayment-river-reservoir system. Ultimately, these efforts will result in a quantitative baseline of information necessary for assessing the long-term effectiveness of the ORNL Remedial Action Program. 


\section{ABATEMENT PROGRAM}

As specified in the ORNL NPDES permit," an abatement program will be developed if the results of the biological monitoring indicate that stream use classifications are not being met, or more specifically, as potential problems are identified through biological monitoring. DEM will closely monitor all data, as provided by ESD, and will take immediate action as problems are identified. It will be the responsibility of ESD to provide to DEM (1) results of the routine monthly ambient toxicity tests (Sect. 3.1.2) as soon as possible after the tests are completed, (2) monthly progress reports that describe accomplishments of the seven tasks included in BMAP, and (3) comprehensive annual reports of all results obtained from BMAP during the preceding year. Problems identified and verified during the course of routine biological monitoring will be reported to DEM immediately. Once these reports and communications are received, DEM will review them with staff of the Environmental Restoration and Facilities Upgrade (ERFU) Program to determine the appropriate action to be taken. DEM will be responsible for actions taken, with concurrence from ERFU. These actions will take place throughout the life of the permit and BMAP.

The steps taken will include

1. problem/potential problem identified by ESD,

2. information communicated to DEM,

3. discussions between DEM and ERFU,

4. information obtained on possible causes of the problem,

5. appropriate ORNL staff informed and consulted,

6. source of problem identified,

\footnotetext{
"During the 1ife of the permit, water quality of White Oak Creek and Melton Branch shall be studied in accordance rith the Biological Monitoring Plan and Abatement Program (Part III.H.). If the stream use classifications are not being met by the conclusion of the evaluation period for the last facility constructed, the permittee shall determine the modifications that are necessary to attain the stream use classification."
} 
7. plans made for abatement with approval of both DEM and ERFU,

8. action taken, and

9. elimination of problem verified through biological monitoring.

In order to provide a comprehensive program and maintain/attain stream use classifications, this abatement program will also incorporate information gathered in the Mercury Assessment Plan, PCB Monitoring Plan, and the Toxicity Control and Monitoring Plan--Toxicity Control Plan. 


\section{REFERENCES}

Abee, H. H. 1953. Radioactivity in the mud of White Oak Lake. ORNL-1580. Oak Ridge National Laboratory, Oak Ridge, Tennessee.

Adams, S. M., and R. B. McLean. 1985. Estimation of largemouth bass, Micropterus salmoides Lacepede, growth using the liver-somatic index and physiological variables. J. Fish Biol. 26:111-126.

Adams, S. M., C. A. Burtis, and J. J. Beauchamp. 1985a. Integrated and individual biochemical responses of rainbow trout (Salmo gairdneri) to varying durations of acidification stress. Comp. Biochem. Physio1. 82C:301-310.

Adams, S. M., J. E. Breck, and R. B. McLean. 1985b. Cumulative stress-induced mortality of gizzard shad in a southeastern U.S. reservoir. Environ. Biol. Fishes 13:103-112.

Addison, R. F. 1981. Hepatic mixed function oxidase (MFO) induction in salmoids by polychlorinated biphenyls (PCB) and related compounds. IN Proceedings of a Fish Health Workshop, Great Lakes Fishery Commission, Geneva Park, Ontario, Canada.

Allison, A. C. 1979. Macrophages and their products in immunoregulation (As effectors cells and as targets for adjuvants). pp. 181-186. IN G. H. Werner and F. Floch (eds.), The Pharmacology of Immunoregulation. Academic Press, New York.

Anderson, R. O., and S. J. Gutreuter. 1983. Length, weight, and associated structural indices. pp. 283-300. IN L. A. Nielson and D. L. Johnson (eds.), Fisheries Techniques. Southern Printing Company, Blacksburg, Virginia.

Anderson, S. H., L. K. Mann, and H. H. Shugart. 1977. The effect of transmission line corridors on bird populations. Am. Midl. Nat. $97(1): 216-221$.

Ashwood, T. L., C. R. 01sen, I. L. Larsen, and P. D. Lowry. 1986. Sediment contamination in streams surrounding the Oak Ridge Gaseous Diffusion Plant. ORNL/TM-9791. Oak Ridge National Laboratory, Oak Ridge, Tennessee. 
Auerbach, S. I. 1957. Ecological research. pp. 10-39. IN Health Physics Division Annual Progress Report for Period Ending July 31, 1957. ORNL-2384. Oak Ridge National Laboratory, Oak Ridge, Tennessee.

Auerbach, S. I. 1958. Ecological research. pp. 27-52. IN Health Physics Division Annual Progress Report for Period Ending July 31, 1958. ORNL-2590. Oak Ridge National Laboratory, Oak Ridge, Tennessee.

Auerbach, S. I. 1959. Ecological research. pp. 18-54. IN Health Physics Division Annual Progress Report for Period Ending July 31, 1959. ORNL-2806. Oak Ridge National Laboratory, Oak Ridge, Tennessee.

Auerbach, S. I. 1960. Ecological research. pp. 147-166. IN Health Physics Division Annual Progress Report for Period Ending July 31, 1960. ORNL-2994. Oak Ridge National Laboratory, Oak Ridge, Tennessee.

Buerbach, S. I. 1961. White Oak Lake bed studies. pp. 81-105.

IN Health Physics Division Annual Progress Report for Period Ending July 31, 1961. ORNL-3189. Oak Ridge National Laboratory, Oak Ridge, Tennessee.

Auerbach, S. I. 1962. Radiation ecology. pp. 47-72. IN Health Physics Division Annual Progress Report for Period Ending July 31, 1962. ORNL-3347. Oak Ridge National Laboratory, Oak Ridge, Tennessee.

Auerbach, S. I. 1963. Radiation ecology. pp. 81-115. IN Health Physics Division Annual Progress Report for Period Ending June 30, 1963. ORNL-3492. Oak Ridge National Laboratory, Oak Ridge, Tennessee.

Auerbach, S. I. 1974. Environmental Sciences Division Annual Progress Report for Period Ending September 30, 1973. ORNL-4935.

Oak Ridge National Laboratory, Oak Ridge, Tennessee. 
Auerbach, S. I., and D. A. Crossley, Jr. 1958. Strontium-90 and cesium-137 uptake by vegetation under natural conditions. pp. 494-499. IN Proceedings of the 2nd International Conference on Peaceful Uses of Atomic Energy, Geneva, Vo1. 18. Pergamon Press, London.

Auerbach, S. I., and J. S. 01son. 1963. Biological and environmental behavior of ruthenium and rhodium. pp. 509-519. IN V. Schultz and A. W. Klement, Jr. (eds.), Radioecology: Proceedings of the First National Symposium on Radioecology, held at Colorado State University, Fort Collins, Colorado, September 10-15, 1961. Reinhold Publishing Corp., New York.

Bagena1, T. B. 1978. Aspects of fish fecundity. pp. 75-101.

IN S. D. Gerking (ed.), Ecology of Freshwater Fish Production. John Wiley and Sons, New York.

Bagenal, T. B., and E. Braum. 1978. Eggs and early life history. pp. 165-201. IN T. Bagenal (ed.), Methods for Assessment of Fish Production in Fresh Waters, 3rd ed. IBP Handbook No. 3. Blackwell Scientific Publications, Oxford, England.

Benke, A. C. 1984. Secondary production of aquatic insects. pp. 289-322. IN V. H. Resh and D. M. Rosenberg (eds.), The Ecology of Aquatic Insects. Praeger Publishers, New York.

Blaylock, B. G. 1965. Chromosomal aberrations in natural populations of Chironomus tentans exposed to chronic low-level radiation. Evolution 19(3):421-429.

Blaylock, B. G. 1966. Chromosomal polymorphism in irradiated natural populations of Chironomus. Genetics 53(1):131-136.

Blaylock, B. G. 1969. The fecundity of Gambusia affinis populations exposed to chronic environmental radiation. Radiat. Res. $37: 108-117$.

Blaylock, B. G., and M. L. Frank. 1979. Distribution of tritium in a chronically contaminated lake. pp. 247-256. IN Behavior of Tritium in the Environment. IAEA-SM-232/74. International Atomic Energy Agency, Vienna. 
Blaylock, B. G., and J. R. Trabalka. 1978. Evaluating the effects of ionizing radiation on aquatic organisms. pp. 103-152. IN Advances in Radiation Biology, Vo1. 7. Academic Press, New York.

Bondietti, E. A., and C. T. Garten. 1986. Speciation of ${ }^{99} \mathrm{Tc}$ and ${ }^{60} \mathrm{Co}$ : Correlation of laboratory and field observations. pp. 79-92.

IN R. A. Bulman and J. R. Cooper (eds.), Speciation of Fission and Activation Products in the Environment. Elsevier Applied Science Publishers, New York.

Bondietti, E. A., and F. H. Sweeton. 1977. Transuranic speciation in the environment. pp. 449-476. IN M. G. White and P. B. Dunaway (eds.), Transuranics in Natural Environments. NVO-178. National Technical Information Service, Springfield, Virginia.

Bondietti, E. A., S. A. Reynolds, and M. H. Shanks. 1976. Interaction of plutonium with complexing substances in soils and natural waters. pp. 273-287. IN Transuranium Nuclides in the Environment: Proceedings of the Symposium on Transuranium Nuclides in the Environment, San Francisco, November 17-21, 1975. International Atomic Energy Agency, Vienna.

Bott, T. L. 1983. Primary productivity in streams. IN J. R. Barnes and G. W. Minshall (eds.), Stream Ecology: Application and Testing of General Ecological Theory. Plenum Press, New York.

Boyle, J. W., R. Blumberg, S. J. Cotter, G. S. Hill, C. R. Kerley, R. H. Ketelle, R. L. Kroodsma, D. W. Lee, R. C. Martin, R. D. Roop, D. N. Secora, W. P. Staub, and R. E. Thoma. 1982. Environmental analysis of the operation of the Oak Ridge National Laboratory (X-10 Site). ORNL-5870. Oak Ridge National Laboratory, Oak Ridge, Tennessee.

Bradburn, D. M., and E. H. Rosenbalm. 1984. Resource Management Plan for the U.S. Department of Energy Oak Ridge Reservation, Vo1. 6: Appendix F: Forest Management. ORNL-6026/V6. Oak Ridge National Laboratory, Oak Ridge, Tennessee.

Brisbin, I. L., Jr., and M. J. Vargo. 1982. Four-year declines in radiocesium concentrations of American coots inhabiting a nuclear reactor cooling reservoir. Health Phys. 43(2):266-269. 
Brisbin, I. L., Jr., R. A. Griger, and M. H. Smith. 1973. Accumulation and redistribution of radiocesium by migratory waterfowl inhabiting a reactor cooling reservoir. pp. 373-383. IN Environmental Behavior of Radionuclides Released in the Nuclear Industry: Proceedings of a Symposium, Aix-en-Provence, France, May 14-18, 1973. International Atomic Energy Agency, Vienna. Bromage, N. R., C. Whitehead, and B. Breton. 1982. Relationships between serum levels of gonadotrophin, oestradiol.17B, and vitellogenin in the control of ovarian development in the rainbow trout. Gen. Comp. Endocrinol. 47:366-376.

Buikema, A. L., B. R. Niederlehner, and J. Cairns. 1982. Biological monitoring: Part IV--Toxicity testing. Water Res. 16:239-262.

Cairns, J. 1974. Indicator species vs the concept of community structure as an index of pollution. Water Resour. Bu1l. 10:338-347.

Caldwel1, R. S. 1974. Osmotic and ionic regulation in decapod crustacea exposed to methoxychlor. pp. 197-223. IN F. J. Vernberg and W. B. Vernberg (eds.), Pollution and Physiology of Marine Organisms. Academic Press, New York.

Callahan, M. A., M. W. Slimak, N. W. Gabel, I. P. May, C. F. Cowler, J. F. Freed, P. Jennings, R. I. Durfee, F. C. Whitmore, B. Maestri, W. R. Mabey, B. R. Holt, and C. Gould. 1979. Water related fate of 129 priority pollutants, Vol. II: Halogenated aliphatic hydrocarbons, halogenated esters, monocyclic aromatics, phthalate esters, polycyclic aromatic hydrocarbons, nitrosamines, and miscellaneous compounds. EPA-440/4-79-029b. U.S. Environmenta1 Protection Agency, Washington, D.C.

Carle, F. L., and M. R. Strub. 1978. A new method for estimating population size from removal data. Biometrics 34:621-630.

Carney, S. M., M. F. Sorensen, and E. M. Martin. 1983. Waterfowl harvest and hunter activity in the United States during the 1982 hunting season. Administrative Report, June 21, 1983. Office of Migratory Bird Management, U.S. Fish and Wildlife Service, Laure1, Maryland.

Carter, L. 1962. Bioassay of trade wastes. Nature 196:1304. 
Carrigan, R. J., Jr. 1969. Inventory of radionuclides in bottom sediment of the Clinch River in Eastern Tennessee. U.S. Geological Survey Professional Paper 433-I. U.S. Government Printing Office, Washington, D.C.

Cerling T. E., and R. R. Turner. 1982. Formation of freshwater Fe-Mn coatings on gravel and the behavior of ${ }^{60} \mathrm{Co},{ }^{90} \mathrm{Sr}$, and ${ }^{137} \mathrm{Cs}$ in a small watershed. Geochim. Cosmochim. Acta 46:1333-12+3.

Chambers, J.E. 1979. Introduction of microsomal mixed function oxidase system components in striped mullet by short-term exposure to crude oil. Toxicol. Lett. 4:227-230.

Cheka, J. S., and K. Z. Morgan. 1947. Radioactive fission product contamination in mud of White Oak drainage system. Report No. MON. H-258. U.S. Atomic Energy Commission, Oak Ridge, Tennessee.

Childs, H. E., Jr., and G. E. Cosgrove. 1966. A study of pathological conditions in wild rodents in radioactive areas. Am. Midl.

Nat. $76: 309-324$.

Cooley, J. L. 1973. Effects of chronic environmental radiation on a natural population of the aquatic snail Physa heterostropha. Radiat. Res. 549(1):130-140.

Cowser, K. E., D. G. Jacobs, T. Tamura, H. J. Wyrick, W. De Laguna, T. F. Lomenick, R. L. Bradshaw, and R. M. Richardson. 1960. Disposal of ORNL wastes. pp. 15-21. IN Health Physics Division Annual Progress Report for Period Ending July 31, 1960. ORNL-2994. Oak Ridge National Laboratory, Oak Ridge, Tennessee.

Cowser, K. E., W. S. Syner, C. P. McCammon, C. P. Straub, O. W. Kochtitzky, R. L. Hervin, E. G. Struxness, and R. J. Morton. 1966. Evaluation of radiation dose to man from radionuclides released to the Clinch River. pp. 639-671. IN Disposal of Radioactive Wastes into Seas, Oceans, and Surface Waters: Proceedings of a Symposium, Vienna, May 16-20, 1966. International Atomic Energy Agency, Vienna. 
Crossley, D. A., Jr. 1963. Movement and accumulation of radiostrontium and radiocesium in insects. pp. 103-105. IN V. Schultz and A. W. Klement, Jr. (eds.), Radioecology: Proceedings of the First National Symposium on Radioecology, held at Colorado State University, Fort Collins, Colorado, September 10-15, 1961. Reinhold Publishing Corp., New York.

Crossley, D. A., Jr. 1969. Comparative movement of ${ }^{106} \mathrm{Ru},{ }^{60} \mathrm{Co}$, and ${ }^{137} \mathrm{Cs}$ in arthropod food chains. pp. 687-695. IN D. J. Nelson and F. C. Evans (eds.), Symposium on Radioecology: Proceedings of the Second National Symposiun, Ann Arbor, Michigan, May 15-17, 1967. CONF-670503. National Technical Information Service, Springfield, Virginia.

Crossley, D. A., Jr., and H. F. Howden. 1961. Insect-vegetation relationships in an area contaminated by radioactive wastes. Ecology $42: 302-317$.

Crossley, D. A., Jr., and M. E. Pryor. 1960. The uptake and elimination of cesium-137 by a grasshopper--Romalea microptera. Health Phys. 4:16-20.

Cushing, C. E., and D. G. Watson. 1974. Aquatic studies of Gable Mountain Pond. BNWL-1884. U.S. Atomic Energy Commission, Richland, Washington.

Dahlman, R. C., and P. Van Voris. 1976. Cycling of Cs-137 in soil and vegetation of a flood plain 30 years after initial contamination. pp. 291-298. IN C. E. Cushing, Jr. (ed.), Radioecology and Energy Resources. Dowden, Hutchinson, and Ross, Inc., Stroudsburg, Pennsylvania.

Dahlman, R. C., J. T. Kitchings, and J. W. Elwood. 1977. Land and water resources for environmental research on the Oak Ridge Reservation. ORNL/TM-5352. Oak Ridge National Laboratory, Oak Ridge, Tennessee. 
Dahlman, R. C., C. T. Garten, Jr., and R. E. Hakonson. 1980.

Comparative distribution of plutonium in contaminated ecosystems at Oak Ridge, Tennessee, and Los Alamos, New Mexico. pp. 371-380.

IN W. C. Hanson (ed.), Transuranic Elements in the Environment. DOE/TIC-22800. National Technical Information Center, Springfield, Virginia.

Daniel, F. B., D. L. Haas, and S. M. Pyle. 1985. Quantitation of chemically induced DNA strand breaks in human cells via an alkaline unwinding assay. Anal. Biochem. 144:390-402.

Davis, M. B. 1968. Pollen grains in lake sediments: Redeposition caused by seasonal water circulation. Science 162:796-799.

Davis, M. B. 1973. Redeposition of pollen grains in lake sediments. Limnol. Oceanogr. 18:44-52.

Delahunty, G. and V. L. deVlaming. 1980. Seasonal relationships of ovary weight, liver weight and fat stores with body weight in the goldfish, Carassins auratus (L.). J. Fish. Biol. 16:5-13.

Dendy, F. E., W. A. Champion, and R. B. Wilson. 1973. Reservoirs sedimentation surveys in the United States. pp. 349-357.

IN Man-made Lakes: Their Problems and Environmental Effects. Geophysical Monograph Series, Vol. 17. American Geophysical Union, Washington, D.C.

DeSelm, H. R., and R. E. Shanks. 1963. Accumulation and cycling of organic matter and chemical constituents during early vegetational succession on a radioactive waste disposal area. pp. 83-96.

IN V. Schultz and A. W. Klement, Jr. (eds.), Radioecology:

Proceedings of the First National Symposium on Radioecology, held at Colorado State University, Fort Collins, Colorado, September 10-15, 1961. Reinhold Publishing Corp., New York.

DOE (U.S. Department of Energy). 1980. Oak Ridge Reservation Land-Use Plan. ORO-748, Rev. 1. Oak Ridge Operations Land-Use Committee, U.S. Department of Energy, Technical Information Center, Oak Ridge, Tennessee.

Domby, A. H., D. Paine, and R. W. McFarlane. 1977. Radiocesium dynamics in herons inhabiting a contaminated reservoir system. Health Phys. 33:523-532. 
Drummond, R. A., and R. W. Carlson. 1977. Procedures for measuring cough (gil1 purge) rates of fish. EPA-600/3-77-133. U.S. Environmental Protection Agency, Duluth, Minnesota.

Dunaway, P. B., and S. V. Kaye. 1963. Effects of ionizing radiation on mammal populations on the White Oak Lake bed. pp. 333-338.

IN V. Schultz and A. W. Klement, Jr. (eds), Radioecology: Proceedings of the First National Symposium on Radioecology, held at Colorado State University, Fort Collins, Colorado, September 10-15, 1961. Reinhold Publishing Corp., New York.

Dunaway, P. B., and S. V. Kaye. 1964. Weights of cotton rats in relation to season, breeding condition, and environmental radioactive contamination. Am. Midl. Nat. 71:141-155.

Eddy, F. B. 1981. Effects of stress on osmotic and ionic regulation in fish. pp. 77-102. IN A. D. Pickering (ed.), Stress and Fish. Academic Press, New York.

Edgar, D. E. 1978. An analysis of infrequent hydrologic events with regard to existing streamflow monitoring capabilities in White Oak Creek watershed. ORNL/TM-6542. Oak Ridge National Laboratory, Oak Ridge, Tennessee.

Elser, J. J., and B. L. Kimmel. 1985. Nutrient availability for rhytoplankton production in a multiple-impoundment series. Can. J. Fish. Aquat. Sci. 42:1359-1370.

EPA (U.S. Environmental Protection Agency). 1971. Histochemical and cytophotometric assay of acid stress in freshwater fish. Water Pollution Control Research Series. EPA-18050-DXJ-05/71. Pennsylvania State University, University Park.

EPA (U.S. Environmental Protection Agency). 1976. Assays of toxic pollutants by fish blood. EPA-600/3-76-069. U.S. Environmental Protection Agency, Narragansett, Rhode Island.

EPA (U.S. Environmental Protection Agency). 1977. Toxic effects of water soluble pollutants on freshwater fish. EPA-600/3-77-057. U.S. Environmental Protection Agency, Duluth, Minnesota. 
EPA (U.S. Environmental Protection Agency). 1979. Assessment of clinical procedures to evaluate 1 iver intoxication in fish. EPA-600/3-79-088. U.S. Environmental Protection Agency, Duluth, Minnesota.

EPA (U.S. Environmental Protection Agency). 1985a. Guidance on remedial investigations under CERCLA. EPA/540/G-85/002.

U.S. Environmental Protection Agency, Washington, D.C.

EPA (U.S. Environmental Protection Agency). 1985b. Technical support document for water quality-based toxics control.

U.S. Environmental Protection Agency, Office of Water, Washington, D.C.

EPA (U.S. Environmental Protection Agency). 1986. Authorization to discharge under the National Pollutant Discharge Elimination System and Fact Sheet. Permit No. TN0002941. Oak Ridge National Laboratory $(\mathrm{X}-10)$, Oak Ridge, Roane/Anderson Counties, Tennessee. U.S. Environmental Protection Agency, Atlanta.

Erickson, L. C., R. Osieka, N. A. Sharkey, and K. W. Kohn. 1980. Measurement of DNA damage in unlabeled mammalian cells analyzed by alkaline elution and a fluorometric DNA assay. Anal.

Biochem. 106:169-174.

Exxon Nuclear Co., Inc. 1976. Nuclear Fuel Recovery and Recycling Center Environmental Report, Vols. I and II. Docket No. 50-564, December 16, 1976.

Eyman, L. D., and J. R. Trabalka. 1980. Patterns of transuranic uptake by aquatic organisms: Consequences and implications. pp. 612-623. IN W. C. Hanson (ed.), Transuranic Elements in the Environment. National Technical Information Service, Springfield, Virginia.

Fausch, K. D., J. R. Karr, and P. R. Yant. 1984. Regional application of an index of biotic integrity based on stream fish communities. Trans. Am. Fish. Soc. 113:39-55.

Fendley, T. T., M. N. Manlove, and I. L. Brisbin, Jr. 1977. The accumulation and elimination of radiocesium by naturally contaminated wood ducks. Health Phys. 32:415-422. 
Freeman, H. C., and D. R. Idler. 1973. Effects of corticosteroids on liver transaminases in two salmoids, the rainbow trout (Salmo gairdneri) and the brook trout (Salvelinus fontinalis). Gen. Comp. Endocrinol. 20:69-75.

Freeman, H. C., G. B. Sangalang, and J. F. Uthe. 1981. The effects of pollutants on steroid hormone metabolism in fish. pp. 332. IN A. D. Pickering (ed.), Stress and Fish. Academic Press, New York.

Garman, G. C., and T. F. Waters. 1983. Use of the size-frequency (Hynes) method to estimate annual production of a stream fish population. Can. J. Fish. Aquat. Sci. 40:2030-2034.

Gluth, G., and W. Hanke. 1984. A comparison of physiological changes in carp, Cyprinus carpio, induced by several pollutants at sublethal concentration--II. The dependency on the temperature. Comp. Biochem. Physio1. 79C:39-45.

Goldman, C. R., and B. L. Kimme1. 1978. Biological processes associated with suspended sediment and detritus in lakes and reservoirs. pp. 19-44. IN J. Cairns, E. F. Benfield, and J. R. Webster (eds.), Current Perspectives on River-Reservoir Ecosystems. North Am. Benthol. Soc. Publ. 1.

Greeson, P. E., T. A. Ehlke, G. A. Irwin, B. W. Lium, and K. V. Slack. 1977. Methods for collection and analysis of aquatic biological and microbiological samples. Book 5, Chap. A4. IN Techniques of Water-Resources Investigations of the United States Geological Survey. U.S. Government Printing Office, Washington, D.C.

Gregory, S. V. 1983. Plant-herbivore interactions in stream systems. IN J. R. Barnes and G. W. Minshall (eds.), Stream Ecology: Application and Testing of General Ecological Theory. Plenum Press, New York.

Grigal, D. F., and R. A. Goldstein. 1971. An integrated ordinationclassification analysis of an intensively sampled oak-hickory forest. J. Ecol. 59:481-492.

Grizzel, R. A., Jr. 1955. A study of the southern woodchuck, Marmota monax. Am. Midl. Nat. 53:257-293. 
Halford, D. K., and O. D. Markham. 1983. Biological elimination rates of racioisotopes by mallards contaminated at a liquid radioactive waste disposal area. Healch Phys. 45(3):745-756.

Halford, D. K., J. B. Millard, and O. D. Markham. 1978a. Radionuclide concentrations in wild waterfowl using the test reactor area radioactive leaching pond. pp. 47-55. IN 0. D. Markham (ed.), Ecological Studies on the Idaho National Engineering Laboratory Site. IDO-12087. U.S. Department of Energy, Idaho Falls, Idaho.

Halford, D. K., J. B. Millard, and R. G. Schreckhise. 1978b. Retention of activation and fission radionuclides by mallards from the test reactor area radioactive leaching pond. pp. 56-63. IN 0. D. Markham (ed.), Ecological Studies on the Idaho National Engineering Laboratory Site. IDO-12087. U.S. Department of Energy, Idaho Falls, Idaho.

Halford, D. K., J. B. Millard, and O. D. Markham. 1981. Radionuclide concentrations in waterfowl using a liquid radioactive waste disposal area and the potential radiation dose to man. Health Phys. 40:173-181.

Halford, D. K., O. D. Markham, and R. L. Dickson. 1982. Radiation doses to waterfowl using a liquid radioactive waste disposal area. J. Wild1. Manage. 46(4):905-914.

Hamilton, W. J. 1934. The life history of the rufescent woodchuck, Marmota monax refescens. Ann. Carnegie Mus. 23:85-178.

Harrison, F. L., and J. R. Lam. 1985. Partitioning of copper among copper-binding proteins in the mussel Mytilus edulis exposed to soluble copper. Mar. Environ. Res. 16:151-163.

Heidinger, R. C., and S. D. Crawford. 1977. Effect of temperature and feeding rate on the liver-somatic index of largemouth bass (Micropterus salmoides). J. Fish. Res. Board Can. 29:531-534.

Herde, K. E., and J. F. Cline. 1949. Radioactivity in Pekin ducks on the Columbia River. HW-12079. U.S. Atomic Energy Commission, Rich1.and, Washington.

Herde, K. E., R. L. Browning, and W. C. Hanson. 1951. Activity densities in waterfowl of the Hanford Reservation and environs. HW-18645. U.S. Atomic Energy Commission, Richland, Washington. 
Hinton, D. E., and J.A. Couch. 1985. Pathobiological measures of marine pollution effects. pp. 7-32. IN H. H. White (ed.), Concepts in Marine Pollution Measurements. Maryland Sea Grant College, College Park.

Hinton, D. E., D. E. Kendall, and B. B. Silver. 1973. Use of histologic and histochemical assessments in the prognosis of the effects of aquatic pollutants. pp. 194-208. IN J. Cairns and K. L. Dickson (eds.), Biological Methods for the Assessment of Water Quality. ASTM Spec. Tech. Pub. 528. American Society for Testing and Materials, Philadelphia.

Hoffman, F. O., B. G. Blaylock, C. C. Travis, K. L. Daniels, E. L. Etnier, K. E. Cowser, and C. W. Weber. 1984. Preliminary screening of contaminants in sediments. ORNL/TM-9370. Oak Ridge National Laboratory, Oak Ridge, Tennessee.

Hopkins, C. C. E., J. V. Seiring, and 0. Nyholmen. 1984. Ecological energetics from total lipid and total protein: Fact and artifact using a gravimetric method for lipid and a biuret method for protein. Oceanogr. Mar. Biol. Annu. Rev. 22:211-261.

Hughes, G. M. 1981. Effects of low oxygen and pollution on the respiratory systems of fish. pp. 121-146. IN A. D. Pickering (ed.), Stress and Fish. Academic Press, New York.

Huston, M. A. 1979. A general hypothesis of species diversity. Am. Nat. 113:81-101.

Hynes, H. B. N. 1980. A name change in the secondary production business. Limnol. Oceanogr. 25:778.

Hynes, H. B. N. 1984. Aquatic insects and mankind. pp. 578-588. IN V. H. Resh and D. M. Rosenberg (eds.), The Ecology of Aquatic Insects. Praeger, New York.

Jensen, A. J. 1980. The 'gut index': A new parameter to measure the gross nutritional state of arctic char, Salvelinus alpinns (L.) and brown trout, Salmo trutta L. J. Fish Biol. 17:741-747.

Johnson, R. M. 1964. The herpetofauna of the Oak Ridge area. ORNL-3653. Oak Ridge National Laboratory, Oak Ridge, Tennessee. 
Johnson, W. C., R. K. Schreiber, and R. L. Burgess. 1979. Diversity of small mammals in a powerline right-of-way and adjacent forest in East Tennessee. Am. Midl. Nat. 101(1):231-235.

Karr, J. R. 1981. Assessment of biotic integrity using fish communities. Fisheries 6:21-27.

Karr, J. R., P. R. Yant, K. D. Fausch, and I. J. Schlosser. 1984. Evaluation of an index of biotic integrity: Temporal variability and regional application in the Midwest. Environmental Research Brief, EPA-600/D-84-053. U.S. Environmental Protection Agency, Corvallis, Oregon.

Kaye, S. V., and P. B. Dunaway. 1962. Bioaccumulation of radioactive isotopes by herbivorous small mammals. Health Phys. 7:205-217.

Kaye, S. V., and P. B. Dunaway. 1963. Estimation of dose rate and equilibrium state from bioaccumulation of radionuclides by mammals. pp. 107-111. IN V. Schultz and A. W. Klement, Jr. (eds.), Radioecology: Proceedings of the First National Symposium on Radioecology, held at Colorado State University, Fort Collins, Colorado, September 10-15, 1961. Reinhold Publishing Corp., New York.

Kearns, P. K., and G. J. Atchison. 1970. Effects of trace metals on growth of yellow perch (Perca flavescens) as measured by RNA-DNA ratios. Environ. Biol. Fishes 4:384-387.

Kevern, N. L., and N. A. Griffith. 1966. Effect of trophic level on radionuclide accumulation by fish. p. 88. IN Health Physics Division Annual Progress Report for Period Ending July 31, 1966. ORNL-4007. Oak Ridge National Laboratory, Oak Ridge, Tennessee.

Kimme1, B. L. 1978. An evaluation of recent sediment focusing in Castle Lake (California) using a volcanic ash layer as a stratigraphic marker. Verh. Int. Ver. Theor. Angew. Limnol. $20: 393-400$.

Kimmel, B. L., and A. W. Groeger. 1986. Limnological and ecological changes associated with reservoir aging. pp. 103-109. IN G. E. Hall and M. J. Van Den Avyle (eds.), Reservoir Fisheries Management: Strategies for the $80^{\prime} \mathrm{s}$. American Fisheries Society, Bethesda, Maryland. 
Kinter, W. B., L. S. Merkens, R. H. Janicki, and A. M. Guarino. 1972. Studies on the mechanism of toxicity of DDT and polychlorinated biphenyls (PCBs): Disruption of osmoregulation in marine fish. Environ. Health Perspect. 1:169-173.

Kitche11, J. F., D. J. Stewart, and D. Weininger. 1977. Application of a bioenergetics model to yellow perch (Perca flavescens) and walleye (Stizostedion vitreum vitreum) J. Fish. Res. Board Can. 344:1922-1935.

Kitchings, J. T., and L. K. Mann. 1976. A description of the terrestrial ecology of the Oak Ridge Environmental Research Park. ORNL/TM-5073. Oak Ridge National Laboratory, Oak Ridge, Tennessee.

Kitchings, J. T., and J. D. Story. 1984. Resource Management Plan for the U.S. Department of Energy Oak Ridge Reservation, Vo1. 16: Appendix Q: Wildlife management. ORNL-6026/V16. Oak Ridge Nationa1 Laboratory, Oak Ridge, Tennessee.

Kolehmainen, S. E., and D. J. Nelson. 1969. The balances of ${ }^{137} \mathrm{Cs}$, stable cesium, and feeding rates of bluegill (Lepomis macrochirus Raf.) in White Oak Lake. ORNL-4445. Oak Ridge National Laboratory, Oak Ridge, Tennessee.

Kornberg, H. A., and E. G. Swezea. 1962. Hanford biology research annual report for 1961. HW-72500. U.S. Atomic Energy Commission, Richland, Washington.

Kruger, C. C., and T. F. Waters. 1983. Annual production of macroinvertebrates in three streams of different water quality. Ecology $64: 840-850$.

Krumholz, L. A. 1954a. An ecological survey of White Oak Creek, 1950-1953. ORO-587, Vol. I. U.S. Atomic Energy Commission, Division of Technical Information, Oak Ridge, Tennessee.

Krumholz, L. A. 1954b. An ecological survey of the limnology of White Oak Creek and Lake. ORO-587, Vol. II. U.S. Atomic Energy Commission, Division of Technical Information, Oak Ridge, Tennessee.

Krumholz, L. A. 1954c. An ecological survey of the vertebrate fauna of White Oak Lake and environs. ORO-587, Vo1. III. U.S. Atomic Energy Commission, Division of Technical Information, Oak Ridge, Tennessee. 
Lackey, J. B. 1957. The suspended microbiota of the Clinch River and adjacent waters, in relation to radioactivity in the summer of 1956. ORNL-2410. Oak Ridge National Laboratory, Oak Ridge, Tennessee.

Larkin, P. D. 1978. Fisheries management: An essay for ecologists. Annu. Rev. Ecol. Syst. 9:57-73.

LeCren, E. D. 1951. The length-weight relationship and seasonal cycle in gonad weight and condition in the perch (Perca fluviatilis). J. Anim. Ecol . 20:201-219.

Lech, J. J., M. J. Vodicnik, and C. R. Elcombe. 1982. Induction of monooxygenase activity in fish. pp. 107-148. IN L. J. Weber (ed.), Aquatic Toxicology. Raven Press, New York.

Lee, P. K., and S. I. Auerbach. 1959. Determination and evaluation of the radiation field above White Oak Lake bed. ORNL-2755.

Oak Ridge National Laboratory, Oak Ridge, Tennessee.

Loar, J. M. , J. A. Solomon, and G. F. Cada. 1981a. Technical background information for the ORNL Environmental and Safety Report, Vol. 2: A description of the aquatic ecology of White Oak Creek watershed and the Clinch River below Melton Hill Dam. ORNL/TM-7509/V2. Oak Ridge National Laboratory, Oak Ridge, Tennessee.

Loar, J. M. , F. A. Burkhart, G. F. Cada, J. W. Huckabee, J. T. Kitchings, K. D. Kumar, A. M. Sasson, J. A. Solomon, and J. D. Story. 1981b. Ecological studies in the vicinity of the Oak Ridge Gaseous Diffusion Plant. ORNL/TM-6714. Oak Ridge National Laboratory, Oak Ridge, Tennessee.

Loar, J. M., M. J. Sale, G. F. Cada. D. K. Cox, R. M. Cushman, G. K. Eddlemon, J. L. Elmore, A. J. Gatz, P. Kanciruk, J. A. Solomon, and D. S. Vaughan. 1985. Application of habitat evaluation models in southern Appalachian trout streams.

ORNL/TM-9323. Oak Ridge National Laboratory, Oak Ridge, Tennessee. Loar, J. M., S. M. Adams, L. J. Allison, J. M. Giddings, J. F. McCarthy, G. R. Southworth, J. G. Smith, and A. J. Stewart. 1989. The Oak Ridge Y-12 Plant Biological Monitoring and Abatement Program for East Fork Poplar Creek. ORNL/TM-10265. Oak Ridge National Laboratory, Oak Ridge, Tennessee. 
Lomenick, T. F., and D. A. Gardiner. 1965. The occurrence and retention of radionuclides in sediment of White Oak Lake. Health Phys. 11:567-577.

Lomenick, T. F., and T. Tamura. 1965. Naturally occurring fixation of Cs-137 on sediments of lacustrine origin. Soil Sci.. Soc. Am. Proc. $29: 383-387$.

Lomenick, T. F., H. J. Wyrick, R. M. Richardson, W. M. McMasters, and T. W. Hodge, Jr. 1962. Study of the White Oak Creek drainage basin. pp. 27-34. IN Health Physics Division Annua1 Progress Report for Period Ending July 31, 1962. ORNL-3347. Oak Ridge National Laboratory, Oak Ridge, Tennessee.

Majewski, H. S., J. F. Klaverkamp, and D. P. Scott. 1978. Acute lethality and sublethal effects of acetone, ethanol, and propylene glycol on the cardiovascular and respiratory systems of rainbow trout (Salmo gairdneri). Water Res. 13:217-221.

Mann, L. K., and M. W. Bierner. 1975. Oak Ridge, Tennessee, flora: Habitats of the vascular plants--Revised inventory. ORNL/TM-5056. Oak Ridge National Laboratory, Oak Ridge, Tennessee.

Martin Marietta Ene:-gy Systems, Inc. 1985. Environmental monitoring report, United States Department of Energy Oak Ridge Facilities, calendar year 1984. ORNL-6209. Martin Marietta Energy Systems, Inc., Oak Ridge, Tennessee.

Mattice, J. S., and L. L. Wright. 1985. Aspects of growth of the Asiatic clam Corbicula fluminea. ORNL/TM-8910. Oak Ridge National Laboratory, Oak Ridge, Tennessee.

Mattice, J. S., and H. E. Zittel. 1976. Site-specific evaluation of power plant chlorination: A proposal. J. Water Pollut. Control Fed. $48(10): 2284-2308$.

Mayer, F. L., Jr., P. M. Mehrle, Jr., and W. P. Dwyer. 1975. Toxaphene effects on reproduction, growth, and mortality of brook trout. EPA-600/3-75-013. U.S. Environmental Protection Agency, Duluth, Minnesota.

McCarthy, J. F., and B. D. Jimenez. 1985a. Reduced bioavailability to bluegills of polycyclic aromatic hydrocarbons bound to dissolved humic material. Environ. Toxicol. Chem. 4:511-521. 
McCarthy, J. F., and B. D. Jimenez. 1985b. Interactions between polycyclic aromatic hydrocarbons and dissolved humic materials: Binding and dissociation. Environ. Sci. Technol. 19:1072-1076. McCarthy, J. F., B. D. Jimenez, and T. Barbee. 1985. Effect of dissolved humic material on accumulation of polycyclic aromatic hydrocarbons: Structure-activity relationships. Aquat.

Toxicol. 7:15-24.

McFarlane, G. A., and W. G. Franzin. 1978. Elevated heavy metals: A stress on a population of white suckers, Catostomus commersoni, in Hamell Lake, Saskatchewan. J. Fish. Res. Board Can. 35:963-970.

Mcleay, D. J. 1973. Effects of a 12-hr and 25-day exposure to Kraft pulp mill effluent on the blood and tissues of juvenile coho salmon. J. Fish. Res. Board Can. 30:395-400.

McLeay, D. J. 1975. Sensitivity of blood cell counts in juvenile coho salmon (Oncorhynchus kisutch) to stressors including sublethal concentrations of pulpmill effluent and zinc. J. Fish. Res. Board Can. $32: 2357-2367$.

McLeay, D. J. 1977. Development of a blood sugar bioassay for rapidly measuring stressful levels of pulpmill effluent to a salmonid fish. J. Fish. Res. Board Can. 34:477-485.

McLeay, D. J., and M. R. Gordon. 1977. Leucocrit: A simple hematological technique for measuring acute stress in salmonid fish, including stressful concentrations of pulpmill effluent. J. Fish. Res. Board Can. 34:2164-2175.

McMaster, W. M. 1963. Geologic map of the Oak Ridge Reservation, Tennessee. ORNL/TM-713. Oak Ridge National Laboratory, Oak Ridge, Tennessee.

McMaster, W. M. 1967. Hydrologic data for the Oak Ridge area, Tennessee. U.S. Geological Survey Water-Supply Paper No. 1838-N. U.S. Government Printing Office, Washington, D.C.

McMaster, W. M., and H. D. Waller. 1965. Geology and soils of White Oak Creek Basin, Tennessee. ORNL/TM-1108. Oak Ridge National Laboratory, Oak Ridge, Tennessee. 
Means, J. L., D. A. Crerar, M. P. Borcsik, and J. D. Duguid. 1978. Adsorption of Co and selected actinides by $\mathrm{Mn}$ and Fe oxides in soils and sediments. Geochim. Cosmochim. Acta 42:1763-1773.

Mehrle, P. M., Jr., and F. L. Mayer, Jr., 1980. Clinical tests in aquatic toxicology: State of the art. Environ. Health Perspect. 34:139-143.

Millard, J. B., F. W. Whicker, and O. D. Markham. 1978. Gamma emitting radionuclides of the test reactor area leaching ponds. pp. 28-46. IN O. D. Markham (ed.), Ecological Studies on the Idaho National Engineering Laboratory Site. IDO-12087. U.S. Department of Energy, Idaho Falls, Idaho.

Moore, M. H., and A. R. D. Stebbina. 1976. Quantitative cytochemical effects of three metal ions on a lysosomal hydrolase of a hydroid. J. Mar. Biol. Assoc. U.K. 56(4):995-1005.

Morgan, W. S. G. 1977. Biomonitoring with fish: An aid to industrial effluent and surface water quality control. Prog. Technol. $9: 703-711$.

Mount, D. I., and T. J. Norberg. 1984. A seven-day life cycle cladoceran toxicity test. Environ. Toxico1. Chem. 3:425-434.

Mount, D. I., and C. E. Stephan. 1967. A method for establishing acceptable toxicant limits for fish-malathion and the butoxyethanol ester of 2,4-D. Trans. Am. Fish. Soc. 96:185-193.

Mudge, J. E., J. L. Dively, W. H. Neff, and A. Anthony. 1977. Interrenal histochemistry of acid-exposed brook trout, Salvelinus fontinalis (Mitchil1). Gen. Comp. Endocrinol. 31:208-215.

Mundah1, N. D. 1984. Growth and condition of gizzard shad (Dorosoma cepedianum) in Action Lake, Ohio: Relationships to food quality. Ph.D. dissertation. Miami University, Oxford, Ohio.

Nelson, D. J. 1962. Clams as indicators of strontium-90. Science 137:38-39.

Nelson, D. J., J. W. Gooch, N. A. Griffith, and S. A. Rucker. 1970. White Oak Lake studies. pp. 104-106. IN Ecological Sciences Division Annual Progress Report for Period Ending July 31, 1970. ORNL-4634. Oak Ridge National Laboratory, Oak Ridge, Tennessee. 
Norberg, T. J., and D. I. Mount. 1985. A new subchronic fathead minnow (Fimephales promelas) toxicity test. Environ. Toxicol. Chem. $4: 711-718$.

NRC (National Research Council). 1981. Testing for Effects of Chemicals on Ecosystems. National Academy Press, Washington, D.C. Oakes, T. W., and K. E. Shank. 1979. Radioactive waste disposal areas and associated environmental surveillance data at Oak Ridge National Laboratory. ORNL/TM-6893. Oak Ridge National Laboratory, Oak Ridge, Tennessee.

Oakes, T. W., B. A. Kelley, W. F. Ohnesorge, J. C. Bird, K. E. Shank, and F. S. Tsakeres. 1982a. Technical background information for the Environmental and Safety Report, Vol. 4: White Oak Lake and Dam. ORNL-5681. Oak Ridge National Laboratory, Oak Ridge, Tennessee.

Oakes, T. W., F. W. Ohnesorge, J. S. E1dridge, T. G. Scott, D. W. Parsons, H. M. Hubbard, O. M. Sealand, K. E. Shank, and L. D. Eyman. 1982b. Technical background information for the Environmental and Safety Report, Vol. 5: The 1977 Clinch River Sediment Survey-Data presentation. ORNL-5878. Oak Ridge National Laboratory, Oak Ridge, Tennessee.

Oikari, A. O. J., and T. Nakari. 1982. Kraft pulp mill effluent components cause liver dysfunciion in trout. Bull. Environ. Contam. Toxicol. 28:266-270.

Olsen, C. R., P. D. Lowry, S. Y. Lee, I. L. Larsen, and N. H. Cutshall. 1983. Chemical, geological and hydrological factors governing radionuclide migration from a formerly used seepage trench: A field study. ORNL/TM-8839. Oak Ridge National Laboratory, Oak Ridge, Tennessee.

olsen, C. R., I. L. Larsen, P. D. Lowry, N. H. Cutsha11, and M. M. Nichols. 1986. Geochemistry and deposition of ${ }^{7} \mathrm{Be}$ in river-estuarine and coastal waters. J. Geophys. Res. 91:896-908. 0lson, J. S., G. Cristofolini, and S. Cristofolini (eds.). 1966. Oak Ridge, Tennessee, flora: I. Preliminary alphabetic inventory of vascular plants. ORNL/TM-1232. Oak Ridge National Laboratory, Oak Ridge, Tennessee. 
Paine, J. F., and L. L. Fancey. 1981. Mixed function oxidase enzyme induction as a biological monitor and indicator in aquatic Eoxicology: Further studies. IN Proceedings of a Fish Health Workshop, Great Lakes Fishery Commission, Geneva Park, Ontario, Canada.

Parker, F. L., M. A. Churchill, R. W. Andrew, B. J. Frederick, P. H. Carrigan, J. S. Cragwall, S. L. Jones, E. G. Struxness, and R. J. Morton. 190u. Dilution, dispersion and mass transport of radionuclides in the $\mathrm{Clinch}$ and Tennessee Rivers. Pp. 33-55. IN Disposal of Radioactive Wastes into Seas, Oceans, and Surface Waters: Proceedings of a Symposium, Vienna, May 16-20, 1966. International Atomic Energy Agency, Vienna.

Parodi, S., M. Taningher, P. Boero, and L. Santi. 1982. Quantitative correlations amongst alkaline DNA fragmentation, DNA covalent binding, mutagenicity in the Ames test, and carcinogenicity for 21 compounds. Mutat. Res. 93:1-24.

Parr, P. D. 1984a. Resource Management Plan for the U.S. Department of Energy Oak Ridge Reservation, Vo1. 4: Appendix D: Endangered and threatened plant species. ORNL-6026/V4. Oak Ridge National Laboratory, Oak Ridge, Tennessee.

Parr, P. D. 1984b. Endangered and threatened plant species on the Department of Energy Oak Ridge Reservation--An update. J. Tenn. Acad. Sci. 59:65-68.

Peltier, W. H., and C. I. Weber. 1985. Methods for measuring the acute toxicity of effluents to freshwater and marine organisms. EPA 600/4-85/013. U.S. Environmental Protection Agency, Cincinnati, Ohio.

Pickering, R. J., P. H. Carrigan, T. Tamura, H. H. Abee, J. W. Beverage, and R. W. Andrew. 1966. Radioactivity in bottom sediment of the Clinch and Tennessee Rivers. pp. 57-88. IN Disposal of Radioactive Wastes into Seas, Oceans, and Surface Waters: Proceedings of a Symposium, Vienna, May 16-20, 1966. International Atomic Energy Agency, Vienna. 
Platts, W. S., W. F. Megahan, and G. W. Minshall. 1983. Methods for evaluating stream, riparian, and biotic conditions. U.S. Forest Service General Technical Report INT-138. U.S. Forest Service, Intermountain Forest and Range Experiment Station, Ogden, Utah.

Plonka, A., and W. Neff. 1969. Mucopolysaccharide histochemistry of gill epithelial secretions in brook trout exposed to acid $\mathrm{pH}$. Proc. Pa. Acad. Sci. 43:53-56.

Poels, C. L. M., M. W. Van Der Gaag, and J. F. J. Van De Kerkhoff. 1980. An investigation into the long-term effects of Rhine water on rainbow trout. Water Res. 14:1029-1035.

Project Management Corporation. 1975. Clinch River Breeder Reactor Environmental Report, Vols. I-III. Docket No. 50-537, April 10, 1975.

Rao, K. R., F. R. Fox, P. J. Conklin, A. C. Cantelino, and A. C. Brannon. 1979. Physiological and biochemical investigations of the toxicity of pentachlorophenol to crustaceans. pp. 307-339. IN W. B. Vernberg (ed.), Marine Pollution: Functional Responses. Academic Press, New York.

Ricker, W. E. 1946. Production and utilization of fish populations. Ecol. Monogr. 16:373-391.

Sale, P. F. 1979. Habitat partitioning and competition in fish communities. pp. 323-331. IN H. Clepper (ed.), Predator-Prey Systems in Fisheries Management. Sport Fishing Institute, Washington, D.C.

Sangalang, G. B., and H. C. Freeman. 1974. Effects of sublethal cadmium on maturation and testosterone and II-ketotestosterone production in vivo in brook trout. Biol. Reprod. 11:429-435.

Schafer, R. D. 1961. Effects of pollution on the free amino acid content of two marine invertebrates. Pac. Sci. 15:49-55.

Schlosser, I. J. 1982. Fish community structure and function along two habitat gradients in a headwater stream. Ecol. Monogr. 52:395-414. Schreck, C. B., and H. W. Lorz. 1978. Stress response of coho salmon (Oncorhynchus kisutch) elicited by cadmium and copper and potential use of cortisol as an indicator of stress. J. Fish. Res. Board Can. $35: 1124-1129$. 
Seaburg, K. G. 1956. A stomach sampler for live fish. Prog. Fish Cult. $19(3): 137-139$.

Sherwood, C. B., and J. M. Loar. 1987. Environmental data for the White Oak Creek/White Oak Lake watershed. ORNL/TM-10062.

Oak Ridge National Laboratory, Oak Ridge, Tennessee.

Shugart, L. 1985. Quantitating exposure to chemical carcinogens:

In viva alkylation of hemoglobin by benzo(a)pyrene.

Toxicology $34: 211-220$.

Shulman, G. E. 1974. Life cycles of fish. Physlology and Biochemistry. John Wiley and Sons, New York.

Silbergeld, E. K. 1974. Blood glucose: A sensitive indicator of environmental stress in fish. Bull. Environ. Contam. Toxicol. $11: 20-25$.

Spalding, B. P., and T. E. Cerling. 1979. Association of radionuclides with streambed sediments in White Oak Creek watershed. ORNL/TM-6895. Oak Ridge National Laboratory, Oak Ridge, Tennessee.

Sprague, J. B. 1971. Measurement of pollutant toxicity to fish: Sublethal effects and "safe" concentrations. Water Res. 5:245-266. Sprague, J. B. 1976. Current status of sublethal tests of pollutants on aquatic organisms. J. Fish. Res. Board Can. 33:1988-1992.

Stair, D. M., V. R. Tolbert, and G. L. Vaughan. 1984. Comparison of growth, population structure, and food of creek chub Semotilus atromaculatus in undisturbed and surface-mining-disturbed streams in Tennessee. Environ. Pollut. Ser. A: 35:331-334.

Steel, R. G. D., and J. H. Torrie. 1960. Principles and Procedures of Statistics with Special Reference to the Biological Sciences. McGraw-Hill Book Company, New York.

Steigen, A. L., and G. G. Raddum. 1981. Effects of acidified water on behavior and energy content in the water-louse Asellus aquaticus (L). pF. 113-118. IN R. Singer (ed.), Effects of Acid Precipitation on Benthos. North American Benthological Society, Springfield, Illinois . 
Stueber, A. M., D. A. Webster, I. L. Munro, N. D. Farrow, and T. G. Scott. 1981. An investigation of radionuclide release from Solid Waste Disposal Area 3, Oak Ridge National Laboratory. ORNL/TM-7323. Oak Ridge National Laboratory, Oak Ridge, Tennessee.

Syed, A., T. L. Coombs, and H. M. Keir. 1979. Effects of cadmium on copper-dependent enzymes in the plaice Pleuronectes platessa. Biochem. Soc. Trans. 7:711-713.

Talbot, R. W., and A. W. Andren. 1984. Seasonal variations of ${ }^{210} \mathrm{~Pb}$ and ${ }^{210}$ Po concentrations in an oligotrophic lake. Geochim. Cosmochim. Acta $48: 2053-2063$.

Tamura, T. 1976. Physical and chemical characteristics of plutonium in existing contaminated soils and sediments. pp. 213-222. IN Transuranium Nuclides in the Environment: Proceedings of the Symposium on Transuranium Nuclides in the Environment, San Francisco, November 17-21, 1975. International Atomic Energy Agency, Vienna.

TDPH (Tennessee Department of Public Health). 1978. Water Quality Management Plan for the Clinch River Basin. Division of Water Quality Control, Tennessee Depariment of Public Health, Nashville, Tennessee.

Threlkeld, S. T. 1983. Spatial and temporal variation in the summer zooplankton community of a riverine reservoir. Hydrobiology 107:249-254.

Thurberg, F. P., M. A. Dawson, and R. Collier. 1973. Effects of copper and cadmium on osmoregulation and oxygen consumption in two species of estuarine crabs. Mar. Biol. 23:171-175.

Trabalka, T. J., and C. P. Allen. 1977. Aspects of fitness of a mosquitofish Gambusia affinis population exposed to chronic low-level environmental radiation. Radiat. Res. 70:198-211.

Turner, R. R., C. R. Olsen, and W. J. Wilcox, Jr. 1985. Environmental fate of $\mathrm{Hg}$ and ${ }^{137} \mathrm{Cs}$ discharged from Oak Ridge facilities. pp. 329-338. IN D. D. Hemphill (ed.), Trace Substances in Environmental Health--XVIII, Proceedings of the 18 th Annual Conference on Trace Substances in Environmental Health, University of Missouri, Columbia, Missouri, June 4-7, 1984. 
TVA (Tennessee Valley Authority). 1985. Instream contaminant study, Task 4: Fish sampling and analysis. Report to U.S. Department of Energy, Oak Ridge Operations Office. Tennessee Valley Authority, Office of Natural Resources and Economic Development, Knoxville, Tennessee.

Van Voris, P., and R. C. Dahlman. 1976. Floodplain data: Ecosystem characteristics and Cs -137 concentrations in biota and soil. ORNL/TM-5526. Oak Ridge National Laboratory, Oak Ridge, Tennessee.

Vetter, R. D., R. E. Hodson, and C. Arnold. 1983. Energy metabolism in a rapidly developing marine fish egg, the red drum (Sciaenops ocellata). Can. J. Fish. Aquat. Sci. 40:627-634. Waters, T. F. 1977. Secondary production in inland waters. Adv. Ecol. Res. 10:91-164.

Waters, T. F., and J. C. Hokenstrom. 1980. Annual production and drift of the stream amphipod Gammarus pseudolimnaeus in Valley Creek, Minnesota. Limnol. Oceanogr. 25:700-710.

Weber, C. I. (ed.). 1973. Biological field and laboratory methods for measuring the quality of surface waters and effluents. EPA 670/4-73-001. National Environmental Research Center, U.S. Environmental Protection Agency, Cincinnati.

Wedemeyer, G. A., and D. J. Mcleay. 1981. Methods for determining the tolerance of fishes to environmental stressors. pp. 247-275. IN A. Pickering (ed.), Stress and Fish. Academic Press, New York. Wedemeyer, G. A., F. P. Meyer, and L. Smith. 1976. Environmental stress and fish diseases. Book 5. IN S. F. Snieszko and H. R. Axelrod (eds.), Diseases of Fishes. T.H.F. Publications, Inc. Ltd., Neptune City, New Jersey.

Willard, W. K. 1960. Avian uptake of fission products from an area contaminated by low-level atomic wasties. Science 132:148-150.

Windel1, J. R., and S. H. Bowen. 1978. Methods for study of fish diets based on analysis of stomach contents. pp. 219-226. IN T. Bagenal (ed.), Methods for Assessment of Fish Production in Fresh Waters. Blackwell Scientific Publications, Cxford, England. 
Yevich, P. P. 1981. The value of histopathology in the aquatic sciences. IN Proceedings of a Fish Health Workshop, Great Lakes Fishery Commission, Geneva Park, Ontario, Canada. 
ORNL/TM- 10370

INTERNAL DISTRIBUTION

1. S. M. Adams

2-6. L. J. Allison

7. S. I. Auerbach

8. L. D. Bates

9. B. G. Blaylock

10-11. H. L. Boston

12. R. B. Clapp

13. G. F. Cada

14. S. W. Christensen

15. K. W. Cook

16. C. C. Coutant

17. N. W. Durfee

18. D. E. Fowler

19. C. W. Francis

20. M. W. Francis

21. M. L. Frank

22. H. R. Gaddis

23. C. T. Garten

24. C. W. Gehrs

25. C. D. Goins

26. J. A. Greene

27. S. G. Hildebrand

28. M. A. Huston

29. S. V. Kaye

30. B. L. Kimmel

31. A. J. Kuhaida, Jr.

32. J. R. Lawson

33-42. J. M. Loar

43. P. Y. Lu

\author{
44. C. E. Nix \\ 45-48. P. T. Owen \\ 49. G. E. Rymer \\ 50. M. G. Ryon \\ 51. G. R. Southworth \\ 52. L. R. Shugart \\ 53. J. G. Smith \\ 54. A. J. Stewart \\ 55. S. H. Stow \\ 56. G. W. Suter \\ 57. D. W. Swindle \\ 58. J. R. Trabalka \\ 59. C. K. Valentine \\ 60. W. Van Winkle \\ 61. L. D. Voorhees \\ 62. B. T. Walton \\ 63. D. R. Watkins \\ 64. R. K. White \\ 65. Central Research Library \\ 66-80. ESD Library \\ 81. ER Document Management Ctr \\ 82-83. Laboratory Records Department \\ 84. Laboratory Records-RC \\ 85. ORNL Patent Office \\ 86. ORNL Y-12 Technical Library
}

EXTERNAL DISTRIBUTION

87. S. Ahlstedt, Division of Water Resources, Tennessee Valley Authority, Norris, TN 37828

88. D. S. Day, Environmental Division, U.S. Department of Energy, Savannah River Operations Office, Box A, Aiken, SC 29802

89. P. H. Edmonds, Lee Wan and Associates, 120 South Jefferson Circle, Oak Ridge, TN 37830

90. J. F. Franklin, Bloedel Professor of Ecosystem Analysis, College of Forest Resources, University of Washington, Anderson Hall (AR-10), Seattle, WA 98195

91. C. S. Gist, Environmental Protection Branch, Department of Energy Field Office, Oak Ridge, P.O. Box 2001, Oak Ridge, TN 37831

92. H. W. Hibbitts, Chief, Environmental Protection Branch, Department of Energy Field Office, Oak Ridge, P.0. Box 2001, Oak Ridge, TN $3783 i$

93. D. R. Hopkins, U.S. Environmental Protection Agency, 345 Courtland Street, N.E., Atlanta, GA 30365 
94. G. M. Hornberger, Professor, Department of Environmental Sciences, University of Virginia, Charlottesville, VA 22903

95. G. Y. Jordy, Director, Office of Program Analysis, Office of Energy Research, ER-30, G-226, U.S. Department of Energy, Washington, DC 20545

96. T. Joseph, Environmental Remediation Branch, G-108, Department of Energy Field Office, Oak Ridge, P.O. 2001, Oak Ridge, TN 37831

97. J. T, Kitchings, Stanford Place 3, Suite 415, 4582 S. Ulster Street Parkway, Denver, CO 80237

98. W. A. Kocher, 1219 Riverbend Drive, Kingston, TN 37763

99. E. C. Leming, Manager, Knoxville Basin Office, Tennessee Department of Health and Environment, 1605 Prosser Road, Knoxville, TN 37914-3434

100. G. J. Marciante, Environmental Protection Branch, Department of Energy Field Office, Oak Ridge, P.O. Box 2001, Oak Ridge, Oak Ridge, TN 37831

101. A. D. Mckinney, Chief, Environmental Services, P.0. Box 40747 , Ellington Agricultural Center, Nashville, TN 37204

102-105. W. E. Murphie, Department of Energy, Office of Environmental Restoration, Eastern Area D\&D Branch, EM-423 (GTN), Washington, DC 20545

106. C. R. Olsen, Environmental Sciences Division, Office of Health and Environmental Research, ER-74, U.S. Department of Energy, Washington, DC 20585

107. R. H. Olsen, Vice President for Research, University of Michigan, Medical Science Building II, \#5605, 1301 East Catherine Street, Ann Arbor, MI 48109-0620

108. A. Patrinos, Acting Director, Environmental Sciences Division, Office of Health and Environmental Research, ER-74, U.S. Department of Energy, Washington, DC 20585

109-110. S. S. Perkins, c/o Labat-Anderson, Inc., Information Resource Center, Administrative Record File, 105 Broadway, Oak Ridge, TN 37830

111-112. S. P. Riddle, Department of Energy Field Office, Oak Ridge, P.O. Box 2001, Oak Ridge, TN 37831-8541

113. W. Schacher, Aquatic Habitat Protection Biologist, Tennessee Wildlife Resources Agency, 6032 W. Andrew Johnson Highway, Talbot, TN 37877

114. R. C. Sleeman, Department of Energy Field Office, Oak Ridge, P.O. Box 2001, Oak Ridge, TN 37831-8541

115. C. R. Wenzel, SAIC, P. O. Box 2501, Oak Ridge, TN 37831-2501

116. F. J. Wobber, Environmental Sciences Division, Office of Health and Environmental Research, ER-74, U.S. Department of Energy, Washington, DC 20585

117. Office of Assistant Manager for Energy Research and Development, Department of Energy Field Office, Oak Ridge, P.0. Box 2001, Oak Ridge, TN 37831-8600

118-127. Office of Scientific and Technical Information, P.O. Box 62, Oak Ridge, TN 37831 
$=$
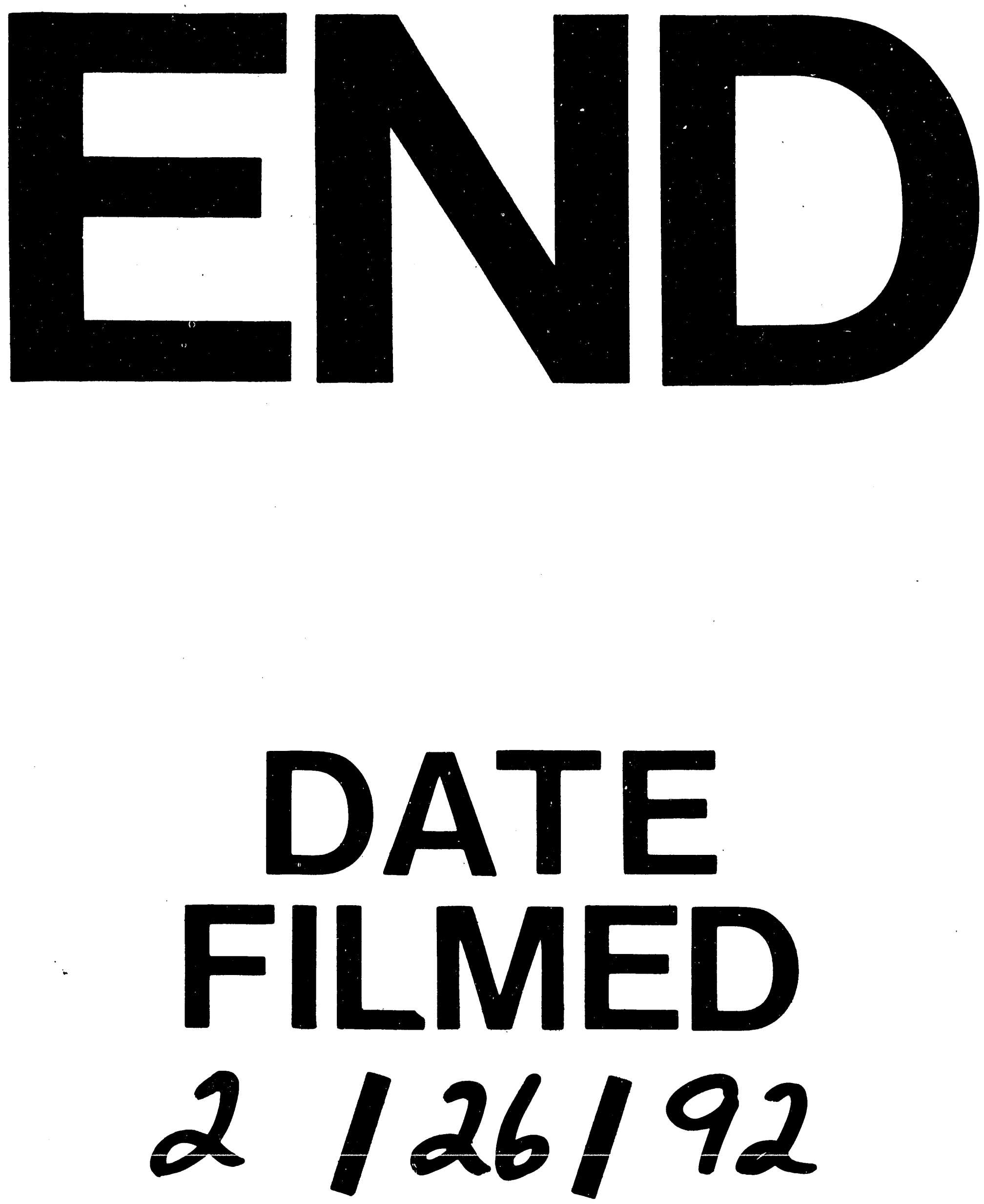
